\title{
COMPLETING THE CIRCLE: ACCOUNTABILITY FOR THE CRIMES OF THE 1971 BANGLADESH WAR OF LIBERATION
}

\section{INTRODUCTION}

There are many policy issues that need to be considered when a country and its people start to deal with horrors that are 39 years old. The trial process is a critical part of that, but it is not the only issue to deal with. It is essential for Bangladesh to develop a comprehensive, coherent and principled strategy for dealing with its past. It has not done that yet. The country is at a critical juncture, and it falls on the government to seize the opportunity to make the most of a process of accountability. Any trial process, especially of such a charged matter as the crimes of the liberation war, must meet international standards in order to have any legitimacy, honour the victims and provide some kind of redress to survivors. But that is not enough. After 38 years, the damage to the fabric of society is immense, and a properly conducted trial process opens a window of opportunity to repair some of the harm. The government must respond appropriately.

My purpose in this paper is not to address the important wider issues of how Bangladesh should deal with the legacies of its past. I wish to focus on the key legal issues arising out of the Awami League government's avowed determination to investigate, prosecute and punish alleged criminals under the International Crimes (Tribunals) Act 1973 As Amended. And, due to constraints of space,

* Suzannah Linton is an Associate Professor in the Department of Law, The University of Hong Kong. I am very grateful to Professor M. Shah Alam and Professor Roger S. Clark for their thoughtful suggestions and observations. Ernest $\mathrm{Ng}$ was an enormous help with research and editing. Thanks are also due to Assistant Professor A.B. Noman. This article was completed in September 2009 and updated in May 2010. 
my aim can only be to draw as many of the noteworthy issues to attention as possible, with some observations in the hope that this can contribute to assisting and improving the process that appears to be moving forward in Bangladesh. Other papers in this Special Edition fill in critical areas that need closer attention. This is, as will be seen from this study, a process that is in need of great assistance from the international community.

\section{BACKGROUND}

Given how little is known internationally about this situation today, I must begin this paper with some context. The tragedy of Bangladesh in 1971 was closely chronicled in the international and domestic media at the time, and there have been many academic studies particularly in the three affected countries. The densely populated territory on the Ganges delta became a medium through which the Cold War superpowers flexed their muscles. International lawyers also followed the situation closely, for it concerned not just important issues of accountability for international crimes, but also secession and self-determination, humanitarian intervention, self-defence in international law, assistance to and exercise of control over armed groups engaged in a struggle for secession in a neighbouring country, recognition of States and internationalisation of a non-international armed conflict. In fact, the creation of the State of Bangladesh out of a secessionist breakaway from a repressive State is the most pertinent example to be cited in favour of the Kosovar Declaration of Independence. When the war was over, there was even a case brought to the International Court of Justice by Pakistan in relation to the Pakistani prisoners-of-war being held by the Indian Army, which is discussed later in this section.

Today's Bangladesh was once part of Pakistan, which was carved out of British India at partition in 1947. ${ }^{1}$ It was known as East

\footnotetext{
${ }^{1}$ Many laws that applied in Pakistan in 1971, including the criminal and criminal procedure codes, have continued to apply in the state of Bangladesh. In 1971, there were a number of applicable treaties and conventions, specifically the Convention on the Prevention and Punishment of the Crime of Genocide, Dec. 9, 1948, 78 U.N.T.S. 277 (entered into force Jan. 12, 1951). [hereinafter Genocide Convention]; the Convention on the Elimination of All Forms of Racial Discrimination, Mar. 7, 1966, 660 U.N.T.S. 195 (entered into force Jan. 4 1969) [hereinafter CERD]; the four Geneva Conventions of 1949 (including the Convention (I) for the Amelioration of the Condition of the Wounded and Sick in Armed Forces in the Field, Aug. 12, 1949, 75 U.N.T.S. 31; Convention (II) for the Amelioration of the Condition of Wounded,
} 
Pakistan. East Pakistan came to be an unhappy member of the Pakistani family. Its grievances included perceived domination by the West, racial and linguistic discrimination and exploitation. ${ }^{2}$ The leaders of East Pakistan began asking for greater autonomy within Pakistan. This was rejected. The tensions were exacerbated when, in 1970, the West failed to respond appropriately to the most devastating cyclone ever to hit the East. In the elections of 1970, the Awami League won a landslide victory (167 of the 169 allotted to East Pakistan) and captured the majority of seats in the Pakistani National Assembly. The Awami League was expecting to head the new government. But, President Yahya Khan then cancelled the Parliamentary session that he had earlier delayed in calling. Over in East Pakistan, the Awami League took to the streets of Dhaka in a 5 day general strike (hartal). They "virtually took over the administration in East Pakistan". ${ }^{3}$ Sheikh Mujibur's historic speech on 7 March 1971 is regarded by Bangladeshis with the same respect as President Abraham Lincoln's Gettysburg address. ${ }^{4}$ There were some skirmishes between the security forces and the Awami League supporters before 25 March 1971, and serious attacks against the Bihari community in Chittagong, ${ }^{5}$ but in general the Awami League actions

Footnote 1 continued

Sick and Shipwrecked Members of Armed Forces at Sea, Aug. 12, 1949, 75 U.N.T.S. 81; Convention (III) relative to the Treatment of Prisoners of War, Aug. 12, 1949, 75 U.N.T.S. 135 and Convention (IV) relative to the Protection of Civilian Persons in Time of War, Aug. 12, 1949, 75 U.N.T.S. 287 (entered into force Oct. 21 1950).

In 1971, Pakistan was a party to the Genocide Convention (ratified on Oct. 12, 1957); CERD (ratified on Sep. 21, 1966) and the four Geneva Conventions of 1949 (all ratified on Jun. 12, 1951). India was a party to the Genocide Convention (ratified on Aug. 27, 1959); CERD (ratified on Dec. 3, 1968) and also the four Geneva Conventions of 1949 (all ratified on Nov. 9, 1950).

${ }^{2}$ See willem VAn Schendel, A history of BANGladesh, Ch. 11-12 (2009).

3 MAHMUdul islam, CONSTitutional LaW of BANGLAdesh 12 (2nd ed., 2002).

${ }^{4}$ Email from M. Shah Alam, Professor of the University of Chittagong (Sept. 5,2009 ) (on file with the author). My thanks to Professor Alam for this insight.

${ }^{5}$ The persons referred to as "Biharis" do not necessarily come from the Indian state of Bihar. They were Indian Moslems who migrated to Bangladesh during the Partition of India.

See INTERNATIONAL COMMISSION OF JURISTS, THE EVENTS IN PAKISTAN: A LEGAL STUDY BY THE SECRETARIAT OF THE INTERNATIONAL COMMISSION OF JURISTS 9 (1972) [hereinafter ICJ EAST PAKISTAN 1971 REPORT] ("Owing to the language difference, assimilation proved difficult in areas where there were large concentrations of Biharis and hostility and resentment developed between the Biharis and Bangladeshis"). They were 
were not violent and there does not seem to have been a Common Article 3 situation, unlike after that date. ${ }^{6}$

There seems little doubt that the human and material cost of the armed conflict that was shortly to follow were enormous. It is difficult to obtain non-partisan and scientifically reliable figures for this conflict. An oft cited international account, derived from Bangladeshi sources, is that a possible three million people lost their lives, ten million fled across the border to India and 200,000-400,000 women were raped, leading to approximately 25,000 pregnancies. $^{7}$ The sexual violence deployed in the Bangladesh war appears to have been used as a weapon of war, and has been likened to the World War II Japanese rapes in Nanjing. According to Brownmiller:

$200,000,300,000$ or possibly 400,000 women (three sets of statistics have been variously quoted) were raped. Eighty percent of the raped women were Moslems, reflecting the population of Bangladesh, but Hindu and Christian women were not exempt.... Hitand-run rape of large numbers of Bengali women was brutally simple in terms of logistics as the Pakistani regulars swept through and occupied the tiny, populous land.... Girls of eight and grandmothers of seventy-five had been sexually assaulted...Pakistani soldiers had not only violated Bengali women on the spot; they abducted tens of hundreds and held them by force in their military barracks for nightly use. ${ }^{8}$

Accounts of the armed conflict are contested and what is described below is merely an attempt to reconstruct relevant aspects of the armed conflict through distillation of the assertions made in a number

\section{Footnote 5 continued}

pro-Pakistan in the struggle for independence. Certain of their members are now widely regarded as targets for prosecution. They live in a limbo-land for they wish to be Pakistani nationals, but Pakistan refuses to grant them nationality, and until recently, they had to live in a country that will not grant them nationality. In 2007, a judgement of the Supreme Court of Bangladesh granted them voting rights and hence citizenship. Those few, who are still not willing to declare their allegiance to Bangladesh and still hoping to be repatriated to Pakistan, are excluded.

${ }^{6}$ This is based on the account as related in the ICJ EAST PAKISTAN 1971 REPORT, supra note 5, at 15-19. As the International Commission of Jurists notes, during the hartal, some acts of violence occurred, but the Awami League were generally able to maintain order.

7 SUSAN BROWNMILLER, AGAinst OUR WILL: MEN, WOMEN AND RAPE 81 (1975) 81. See also Ahmed Ziauddin, The Case of Bangladesh: Bringing to Trial the Perpetrators of the 1971 Genocide, in CONTEMPORARY GENOCIDES: CAUSES, CASES, CONSEQUENCES 99 (Albert J. Jongman ed., 1996). These accounts are verified by more recent Bangladeshi scholarship, but are contested by the Pakistanis, including the Hamoodur Rahman Supplementary Report, infra note 9.

${ }^{8}$ BROWNMILLER, supra note 7, at 81, 83. 
of ostensibly reliable narratives of the conflict. ${ }^{9}$ I do not claim they are factually proven, but the accounts appear to have been responsibly compiled. I rely in particular on the 1972 International Commission of Jurists report, which remains to this day the leading legal analysis of the armed conflict.

\subsection{Operation Searchlight}

Operation Searchlight was led by General Tikka Khan, and involved a full armed assault - using tanks, armoured personnel carriers and troops - on the civilians of Dhaka. On 25 March 1971, after the stealthy departure from Dhaka of Military Chief General Yahya and the leading West Pakistani politician Zulkifar Ali Bhutto in the middle of negotiations with the Awami League, the Pakistani Army which was then in cantonment, emerged from barracks and launched an attack on Dhaka. They had, over the preceding weeks, been reinforced by fresh troops, and weaponry shipped in. This was a carefully planned operation, whose "objectives were to neutralize the political power of the Awami League and to re-establish public order". ${ }^{10}$ Terrorisation seems to have been used as a weapon and an objective. Homes were burned down. Symbols of Bengali nationalism were destroyed. The University of Dhaka and its student supporters of the Awami League were attacked using arms, mortars, tanks, cannons and machine guns. A video showing alleged executions from this time is widely circulating on the internet. ${ }^{11}$ The Police and the East Pakistan Rifles were also attacked.

\footnotetext{
${ }^{9}$ The following account of the armed conflict is derived from numerous sources: ICJ EAST PAKISTAN 1971 REPORT, supra note 5; VAN SCHENDEL, supra note 2, at Ch. 16; BROWNMILLER, supra note 7; ANTHONY MASCARENHAS, BANGLADESH: A LEGACY OF BLOOD (1986); RICHARD SISSON \& LEO E. ROSE, WAR AND SECESSION: PAKISTAN, INDIA AND the creation of Bangladesh (1990); Nitin Pai, The 1971 East Pakistan Genocide A Realist Perspective, the aCorn: the indian national interest, Mar. 25, 2008, available at http://acorn.nationalinterest.in/wp-content/uploads/2008/03/east pakistangenocide1971-nitinpai-25march2008-1.pdf); SUPPLEMENTARY HAMOODUR REHMAN COMMISSION REPORT (UNOFFICIAL VERSION) (2007), available at http:// boltapakistan.files.wordpress.com/2007/08/hamood_ur_rehman_commission.pdf. The Hamoodur Rehman Commission Report itself is available at http://www.bangla 2000.com/Bangladesh/Independence-War/Report-Hamoodur-Rahman/default.shtm and http://www.storyofpakistan.com/art.text.asp?artid $=\mathrm{A} 094 \& \mathrm{Pg}=1$.

${ }^{10}$ SISSON \& ROSE, supra note 9, at 157.

${ }^{11}$ This can be seen at Youtube, Bangladesh Genocide: Dhaka University Massacre, http://www.youtube.com/watch?v=sMg9Ly9nK0g (last visited Nov. 19, 2009).
} 
Then, came the attacks on the Hindu community. Eyewitnesses interviewed by the International Commission of Jurists spoke of the justification given by members of the Pakistani Army: "Hindus are enemies of the State". ${ }^{12}$ It was apparently primarily West Pakistani paramilitaries and some Bengali Moslems who engaged in attacks on the Hindu community. ${ }^{13}$ Armed attacks extended into the countryside, and aerial bombardment was used. There are many accounts of the burning and looting of villages. People would be disappeared by way of a process euphemistically called "being sent to Bangladesh". There was resistance. Amidst the many pages of distressing accounts of the attacks on Bengalis, the International Commission of Jurists devotes several pages of its report to Bengali attacks on the proPakistani Biharis that took place during this stage of the armed conflict. ${ }^{14}$

The little resistance that there was could not match the firepower of the Pakistani Army. Refugees and resistance fighters began flooding into India in massive numbers.

On 26 March 1971, Sheikh Mujibur declared independence from Dhaka "in due fulfillment of the legitimate right of self-determination of the people of Bangladesh" and urged Bangladeshis to "defend the honour and integrity of Bangladesh". ${ }^{15}$ On 10 April 1971, the exiled members of the East Pakistan National and Provincial Assemblies (Awami League-dominated since the election of 1970) confirmed that declaration and formed the government of Bangladesh in exile, although their leader was by then detained in Pakistan. ${ }^{16}$

\subsection{The Return of the Mukti Bahini}

The Awami League regrouped in India and the Mukti Bahini (freedom fighters) began to be assisted in a material sense by India, with advice, training and weapons. India began exercising direct control over the government in exile and the various liberation forces. The first effort to create an organised armed force out of the disparate Bengali groups seems to have occurred on 14 April 1971 when the

\footnotetext{
12 ICJ EAST PAKISTAN 1971 REPORT, supra note 5, at 29.

${ }^{13}$ SISSON \& ROSE, supra note 9, at 177 (The authors also allege that pro-Awami League and anti-West Pakistani Bengali Moslems did little to protect them).

14 ICJ EAST PAKISTAN 1971 REPORT, supra note 5, at 32-36.

15 Bangladesh Proclamation of Independence (Apr. 17, 1971), 11 I.L.M. 119 (1972).

${ }^{16}$ ISLAM, supra note 3, at 13.
} 
Bangladesh government in exile appointed a former army officer, Col. M.A.G. Osmani, as commander in chief of the Bangladesh armed forces. ${ }^{17}$ From this time on, training camps were created, with the assistance of the Indian Border Security Force. "The Indian army had assumed primary responsibility for the arming and training of the Mukti Bahini forces from the Border Security Force on 30 April $1971 \ldots$ Even occasional participation by Indian military personnel in raids across the border was now permitted."18 A command structure was established by the end of May 1971, incorporating a substantial number of the different groups into company units and brigades, and dividing up responsibility for undertaking guerrilla operations in assigned sectors of the territory. ${ }^{19}$ India sent some of the Mukti Bahini around the country for training, including as underwater saboteurs. ${ }^{20}$

After the end of the monsoon period, the Mukti Bahini returned to the fray from India, having been trained and equipped. During their absence, there had been retaliatory attacks on the remaining Bengali civilian community by the Biharis and the Army. There was massive and indiscriminate destruction of villages. This was not spontaneous mob violence, but planned violence. The journalist Anthony Mascarenhas reported, in the UK's Sunday Times, of first hand remarks made to him by military officials about the conduct of the operation, that led the International Commission of Jurists to conclude that "the atrocities committed against the population of East Pakistan were part of a deliberate policy by a disciplined force". ${ }^{21}$

The returning Mukti Bahini were able to engage in increasingly successful guerrilla activity against the Pakistani Army. Their frogmen even managed to sink a number of Pakistani vessels in port. From about May-June, the Mukti Bahini also received artillery support from Indian forces firing from within Indian territory. ${ }^{22}$ "Indian artillery stationed on the border was used on occasion to support Mukti Bahini activities in the immediate transborder areas, usually in response to Pakistani shelling and incursions, if the Indian

\footnotetext{
${ }^{17}$ SISSON \& ROSE, supra note 9 , at 183-184.

${ }^{18} I d$., at 182 .

${ }^{19} I d$., at 184.

${ }^{20} I d$., at 184 .

21 ICJ EAST PAKISTAN 1971 REPORT, supra note 5, at 37.

${ }^{22}$ SISSON \& ROSE, supra note 9, at 185.
} 
reports are taken seriously." 23 The civilian population supported the Mukti Bahini, and in retaliation, the Army conducted search and destroy reprisal operations, attacked villagers, burned villages and crops, and destroyed livestock. As the International Commission of Jurists put it, "Every act of sabotage was followed by reprisals by the armed forces who continued to 'burn and kill' whole villages". ${ }^{24}$

Van Schendel asserts that by November 1971, the liberation forces controlled more than 10 liberated areas along the Indian border. ${ }^{25}$ The Indians and Pakistanis began having border skirmishes. Van Schendel also asserts that in November, an Indian general was put in charge of the joint command of freedom fighters and Indian troops. ${ }^{26}$ By November, the Indian Army was already operating within Bangladesh in support of the Mukti Bahini. On 21 November 1971, the Indian government admitted to incursions into the contested territory with tanks, during which they captured and brought some Pakistani tanks back to India. ${ }^{27}$

It was in this period that the Pakistani Army began to create civilian groups such as the Peace Committee, and later paramilitary or auxiliary groups such as the Razakars, ${ }^{28}$ Al-Shams and Al-Badr. Some were Biharis, but they also included Bengalis. "Their task was to maintain control of the inner areas while the Pakistan army was deployed on the frontier to try and prevent the infiltration of the Mukti Bahini from India and to counter the threat of invasion from

\footnotetext{
${ }^{23} I d$., at 211.

24 ICJ EAST PAKISTAN 1971 REPORT, supra note 5, at 42.

25 VAN SCHENDEL, supra note 2, at 167.

${ }^{26} I d$., at 170 .

27 ICJ EAST PAKISTAN 1971 REPORT, supra note 5, at 43.

28 The current Prime Minister, Sheikh Hasina, in an speech as Opposition Leader on 16 April 1992, cited a Pakistan Gazette notification referring to the Razakars Ordinance, No. X of 1971 (1971) (E. Pak.). The gazette notification, from the Ministry of Defence, and under the Pakistan Army Act, makes it clear that the Razakars were under the control of the Pakistan Army. It includes a statement that "the officer of the Pakistan army under whose command any member of the Razakars is placed shall exercise the same powers in relation to that member as he is authorized to exercise under the said Act in relation to a member of the Pakistan Army placed under his command". See Opposition Leader Sheikh Hasina's parliamentary speech given on 16 April 1992 on the subject of Golam Azam and the public tribunal, in DOCUMENTS ON CRIMES AGAINST HUMANITY COMMITTED BY PAKISTAN ARMY AND THEIR AGENTS IN BANGLADESH DURING 1971137 (1999-2002) [hereinafter Opposition Leader Sheikh Hasina's parliamentary speech given on 16 April 1992].
} 
India which they feared". ${ }^{29}$ All the groups operated under Pakistani command.

\subsection{The Indo-Pakistan War}

From mid-October to 20 November 1971, there was a quantitative and qualitative shift in Indian support to the Mukti Bahini: not just did artillery support increase, but "Indian military forces, including tanks and air power, on a few occasions, were used to back up the Mukti Bahini", although the units were always withdrawn back over the border once the objective was achieved. ${ }^{30}$ This continued to escalate. "After the night of 21 November, however, the tactics changed in one significant way - Indian forces did not withdraw". 31 Several army divisions, already in the territory, "moved into key strategic areas around the principal Pakistani defence positions on or near the Indian border with the objective of either capturing or neutralizing them." 32

It was 2 weeks later, on 3 December 1971, that Pakistan bombed Indian airfields in Amritsar, Pathankot, Srinagar, Awantipur, Uttarlai, Jodhpur, Ambala and Agra, triggering the formal start of the third Indo-Pakistan war. India then invaded West and East Pakistan, and formally recognised the State of Bangladesh on 6 December 1971. On 12 December 1971, Indian troops parachuted into Dhaka and 3 days later, General Niazi surrendered to the Indian commander of the joint Indian-Mukti Bahini force, Lt. General Jagjit Singh Aurora.

In the last few days before the surrender, one of the most serious mass killings of the entire war took place in Dhaka, when intellectuals and professionals were rounded up and summarily executed. It is alleged that this was committed, with the aid of lists of names, by a variety of persons from the Pakistani army, the Razakar and Al-Badr militias, and Jamaat-e-Islam party. The Liberation War Museum has documented many "killings fields" across the country. ${ }^{33}$

29 ICJ EAST PAKISTAN 1971 REPORT, supra note 5, at 41.

${ }^{30}$ SISSON \& ROSE, supra note 9, at 212.

${ }^{31} I d$., at 213.

${ }^{32} I d$., at 213.

${ }^{33}$ See Liberation War Museum, Liberation War, http://www.liberationwarmuseum. org/liberationwar.html (last visited Aug. 30, 2009). 


\subsection{Post-Surrender Retaliatory Violence}

In the chaos and emotion of the post-surrender period, there are many reports that Mukti Bahini exacted vengeance against Razakars, collaborators and West Pakistanis, while mobs attacked the Bihari community. ${ }^{34}$

\subsection{When the war was over}

Obviously, more facts have emerged since the International Commission of Jurists published their report in 1972. Their findings are not the final word, but their legal assessment in Parts IV-VII of the report was careful and knowledgeable and deserves to be closely consulted by those wishing to learn more and to proceed further down the road of accountability. ${ }^{35}$ The report assessed that the Awami League's Unilateral Declaration of Independence was not valid under international law, even under the principle of self-determination; $;{ }^{36}$ in other words, Bangladesh did not come into existence at that stage and remained part of Pakistan. This - a correct assessment in the author's view - sits uneasily with its other finding, that its resistance to Pakistan's armed assault was legitimate, ${ }^{37}$ and begs the question: what else were they supposed to do, when negotiation had failed and they had to resist the armed assaults of their own State, of which they had been elected to Parliament by a majority, with force. The report also found that India (which did not actually raise this) was entitled to intervene in the Bangladeshi conflict by way of the doctrine of humanitarian intervention, ${ }^{38}$ and after being attacked by Pakistan on 3 December 1971, was entitled to use force in self-defence. ${ }^{39}$ On the other hand, India's assistance to the Bangladeshi resistance prior to Pakistan's attack was found to have been in violation of international rules of neutrality and non interference in the internal affairs of Pakistan. ${ }^{40}$ The International Commission of Jurists was ultimately to find that both sides

\footnotetext{
${ }^{34}$ See e.g., ICJ EAST PAKISTAN 1971 REPORT, supra note 5, at 44-45; Pai, supra note 9, at 5. Some call the revenge attacks on the Bihari a "counter-genocide".

35 ICJ EAST PAKISTAN 1971 REPORT, supra note 5, at 49-97.

${ }^{36} I d$., at 74-75. This assessment has been rigorously challenged by M. Rafiqul Islam in his Monash University Ph.D. Thesis, later published as a book: M. RAFIQUL ISLAM, THE BANGLADESH LIBERATION MOVEMENT: INTERNATIONAL LEGAL IMPLICATIONS (1987). My thanks to Professor M. Shah Alam for drawing this to my attention.

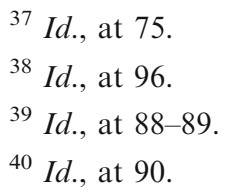


committed violations of international law, although its focus and tenor clearly show that there was no equivalence: the vast bulk of incidents studied involved the Pakistani army and its supporters and paramilitaries/auxiliaries. It found that there was a strong prima facie case that international crimes, namely war crimes and crimes against humanity and breaches of Common Article 3 of the Geneva Conventions 1949 had taken place. The International Commission of Jurists also concluded that acts of genocide against the Hindu group had been perpetrated. They did not identify anyone for investigation and prosecution. I shall leave my consideration of their findings on international criminal law until my later assessment of the International Crimes (Tribunals) Act 1973 As Amended.

After the Pakistani debacle in the east, President Bhutto, who took over from General Yahya Khan, established a judicial commission of inquiry under the chairmanship of the then Chief Justice, Hamoodur Rahman. The Commission examined nearly 213 witnesses and hundreds of classified army signals between East and West Pakistan. Its work comprised a main report submitted in July 1972, and a supplementary report, further to interviews with freshly released prisoners of war and civilian internees in India (a further 72 witnesses were interviewed), that was submitted on 23 October $1974 .{ }^{41}$ Neither was made public for many years; some accounts claimed that Prime Minister Bhutto ordered all copies destroyed. Since 2000, the Supplementary Report has been publicly available, and for sale, having been declassified. The commission placed the blame squarely on the Pakistani Army, and what it saw as moral shortcomings in some of its leaders that came to impact on the situation that arose in East Pakistan. The commission accepted the Pakistani estimates of a death toll of 26,000 persons killed, and rejected the Bangladeshi allegation of 200,000 rapes as being highly exaggerated and "altogether fantastic and fanciful". According to the commission, "[s]o much damage could not have been caused by the entire strength of the Pakistan Army then stationed in East Pakistan even if it had nothing else to do". ${ }^{42}$ The commission named several of Pakistan's top military leaders as having final and overall responsibility for their personal and command roles which "brought disgrace and defeat to Pakistan by their professional incompetence, culpable negligence and willful neglect in the performance of their duties, and physical and moral cowardice in abandoning the fight when they had the

\footnotetext{
${ }^{41}$ SUPPLEMENTARY HAMOODUR REHMAN COMMISSION REPORT, supra note 9 , at 2, 6 .

${ }^{42} I d$., at $18,-32$.
} 
capability and resources to resist the enemy". ${ }^{43}$ This, the commission said, required proper and firm disciplinary action before a court martial, and not merely retirement from service. There could be no "future recurrence of the kind of shameful conduct displayed during the 1971 war". ${ }^{44}$ This was not just about punishing personal failings but was necessary to "emphasize the concept of professional accountability which appears to have been forgotten by senior army officers since their involvement in politics, civil administration and Martial Law duties." 45 This did not exonerate the lower levels, who continued to bear direct responsibility. In respect of the atrocities committed during the conflict, the Commission recommended, inter alia:

a high-powered Court or Commission of Inquiry be set up to investigate into persistent allegations of atrocities said to have been committed by the Pakistan Army in East Pakistan during its operations from March to December, 1971, and to hold trials of those who indulged in these atrocities, brought a bad name to the Pakistan Army and alienated the sympathies of the local population by their acts of wanton cruelty and immorality against our own people. ${ }^{46}$

The Prisoner-of-War situation was significant. India held some 92,000 Pakistani Prisoners-of-War and others. ${ }^{47}$ An Indian government spokesman described the shape of the accountability process that was planned: "two categories of tribunals would be set up shortly to try the war criminals-one exclusively for the trials of those top army officials who were responsible for planning the genocide and the other for the lower ranks who executed the order of the high officials" ${ }^{48}$ The high profile leaders were out of the jurisdiction in Pakistan, but there were 195 suspects being held by India among the 92,000 , and Bangladesh held some 600,000 persons, of which it wanted to expel 260,000 to Pakistan and take criminal proceedings

\footnotetext{
${ }^{43} I d$., at 43,93 .

${ }^{44} I d$.

${ }^{45} I d$., at 22 , 6.

${ }^{46} I d$., at $20,-39$.

${ }^{47}$ Trial of Pakistani Prisoners of War (Pak. v. India) (Req. for the Indication of Interim Measures of Protection) (Order of Jul. 13, 1973), 1, available at http://www.icj-cij.org/docket/files/60/10697.pdf (last visited Aug. 14 2009).

${ }^{48}$ Dhaka Will Try Yahya and Others for War Crimes, Hindustan Times, Feb. 23 1973.
} 
against the rest. On the other side of the sub-continent, Pakistan held some 400,000 Bengalis that it wanted to send back to Bangladesh. ${ }^{49}$

On 11 May 1973, Pakistan brought proceedings against India for the release of its nationals, still being held after the cessation of hostilities on 17 December 1971, in the International Court of Justice. ${ }^{50}$ Pakistan complained about the plans to try 195 of the over 92,000 Pakistani prisoners of war and civilian internees being held by India for alleged genocide. The central issue was whether or not Pakistan had an exclusive claim to exercise jurisdiction in respect of such persons by virtue of Article VI of the Genocide Convention, which both States were party to. ${ }^{51}$ Levie has argued that the real reason for the prolonged detention was to force Pakistani recognition of the State of Bangladesh. ${ }^{52}$ The matter was removed from the list by an Order of 15 December 1973, at the request of Pakistan, in light of negotiations between itself and the Government of India which later resulted in an agreement signed at New Delhi on 28 August 1973. ${ }^{53}$ The agreement was, inter alia, for the release of all but the 195 suspects. In relation to these, India would continue to detain them, and Bangladesh agreed not to prosecute them until resolution of the dispute over what to do with them.

The politics of political recognition and population exchange would ultimately seal the fate of the accountability project in Bangladesh. In April 1974, in return for Pakistan having recognised the existence of Bangladesh, the 195 alleged Pakistani genocidaires were released. The Bangladesh-India-Pakistan Agreement on the Repatriation of War and Civilian Internees (the Simla Agreement) saw the Foreign Minister of Bangladesh state that the Government of Bangladesh has decided not to proceed with the trials against Pakistanis as an act of clemency. ${ }^{54}$ It was agreed that the 195 prisoners of war would be repatriated to Pakistan along with the other prisoners of war already in process of repatriation under the earlier Delhi

\footnotetext{
49 VAN SCHENDEL, supra note 2, at 172; Pai, supra note 9, at 9.

${ }^{50}$ Trial of Pakistani Prisoners of War (Pakistan v. India) (Application Instituting Proceedings) (Application of May 11, 1973), at 3, available at http://www. icj-cij.org/docket/files/60/9461.pdf (last visited Aug. 14 2009).

${ }^{51}$ Genocide Convention, supra note 1, Art. IV.

${ }^{52}$ Howard S. Levie, Legal Aspects of the Continued Detention of the Pakistani Prisoners of War by India, 67 AM. J. INT'L L. 512, 514 (1973).

${ }^{53}$ For analysis, see $I d$.

${ }^{54}$ See Bangladesh-India-Pakistan Agreement on the Repatriation of Prisoners of War and Civilian Internees, Bangl--India-Pak., Apr. 9, 1974, 13 I.L.M. 501 (1974).
} 
Agreement. ${ }^{55}$ There was no obligation by Pakistan to take action against the 195 suspects, or to provide reparation to Bangladesh and its nationals. It was expressly about "reconciliation" and "forget the past", words used in the agreement. This was politics and the issues of international criminal responsibility had become intermeshed with post-war regional disputes and global politics. ${ }^{56}$

\section{THE BANGLADESH COLLABORATORS (SPECIAL TRIBUNALS) ORDER 1972}

The Bangladesh Collaborators (Special Tribunals) Order 1972 (the ' 1972 Collaborators Act') came into force through Presidential Order No. 8 of $1972 .{ }^{57}$ Parliament was not in session, so this was done by a presidential order, later approved by the Parliament that came into being after 1973 General Elections. ${ }^{58}$ It was designed to bring to account those who had collaborated with, or otherwise aided and abetted, the Pakistan Armed Forces, and who waged war or aided and abetted in waging war against Bangladesh.

This law provided for the creation of special tribunals of Sessions judges sitting alone, with exclusive jurisdiction. Senior judges would try the more serious cases. All cases were to be brought by a Public Prosecutor. The tribunals were to use the then-applicable domestic law, that is, identified sections of the Penal Code 1860 and Code of Criminal Procedure 1898. Collaboration was defined at length in Section 2. The cases would be investigated by the Officer in Charge of a police station. Notable provisions included the non-reviewable power granted to the government to extend the period of detention "if, in the opinion of the government, further time is required for completion of the inquiry" 59 and denial of any bail. ${ }^{60}$ The tribunal could 'pardon' a person involved in the crime "on condition of his making a full and true disclosure of the whole circumstances within

\footnotetext{
${ }^{55}$ Id., ฯ 13-15.

${ }^{56}$ Jordan J. Paust \& Albert P. Blaustein, War Crimes Jurisdiction and Due Process: The Bangladesh Experience, 11 VAND. J. TRANSNAT'L L. 1, 31-36 (1978).

${ }^{57}$ President's Order No. 8 of 1972 (1972) (Bangl.); Collaborators (Special Tribunals) Order (1972) (Bangl.).

${ }^{58}$ Email from M. Shah Alam, Professor of the University of Chittagong (Sept. 5, 2009) (on file with the author). My thanks to Professor Alam for this insight.

${ }^{59}$ Collaborators (Special Tribunals) Order, supra note 57, Section 3(5).

${ }^{60} I d$., Section 14.
} 
his knowledge relative to the offence and to every other person concerned". ${ }^{61}$ Property belonging to an accused's minor brothers, sisters or dependants or any benamdar could be seised by the Government. ${ }^{62}$ Appeal to the High Court was possible. ${ }^{63}$ There were no special rules of evidence, so the regular Evidence Act 1872 applied. The death penalty was available.

There are conflicting accounts about the trials that were held under the 1972 Collaborators Act. One account is that the trials took place over 6 months and then ground to a halt. ${ }^{64}$ Another account is that proceedings were taken against 11,000 Bangladeshi suspects in custody, and by 1975, 73 tribunals had been constituted. ${ }^{65}$ Another account, by the same author, in the same paper, is that 37,413 people were arrested under the Act and tried, with 2,848 cases completed. ${ }^{66}$ Another source says that some 30,471 persons were charged, of whom 2,848 were tried, 752 convicted (one to death) and 2096 acquitted. ${ }^{67}$ It seems that, at that time, the trials were regarded as problematic because of systemic flaws in the justice system, and also the difficulty of substantiating charges against the alleged collaborators. $^{68}$

On 30 November 1973, the government declared a general amnesty. Under this, the majority of persons held or convicted (some 35,000 ) were released. ${ }^{69}$ One account for this is that "[a]s the number of accused was very high and many of them committed petty crimes, Sheikh Mujib declared an amnesty but not a blanket one...Those who were punished for or accused of rape, murder, attempt to

${ }^{61}$ This has been included in the International Crimes (Tribunals) Act As Amended, infra, note 79 and will be discussed later in this paper.

${ }^{62}$ Collaborators (Special Tribunals) Order, supra note 57, Section 17.

${ }^{63} I d$., Section 16(1).

${ }^{64}$ Sara Hossain, A Long and Winding Road: Justice and Accountability for War Crimes in 1971, a paper presented at the International Conference on Genocide, Truth and Justice, Dhaka, Bangladesh, Mar. 1-2, 2008, Conference ProceEdings, 52 (2008).

${ }^{65}$ Humayun Reza, War Crimes \& Genocide in 1971: The Reality of the Trial, a paper presented at the International Conference on Genocide, Truth and Justice, Dhaka, Bangladesh, Mar. 1-2, 2008, CONFERENCE PRoceEdings, 55 (2008).

${ }^{66}$ Reza, supra note 65 , at 56.

${ }^{67}$ Hossain, supra note 64, at 53.

${ }^{68} \mathrm{Id}$., at 52.

${ }^{69}$ REDRESS, Torture in Bangladesh 1971-2004, at 27, http://www.redress.org/ publications/Bangladesh.pdf (last visited Aug. 30, 2009). 
murder or arson will not come under general amnesty". ${ }^{70}$ Others point to the exchange of Bangladeshis held in Pakistan with those who were to be returned from Bangladesh to Pakistan, and the much-needed diplomatic recognition by Pakistan. ${ }^{71}$ Another account is that they were released in connection with the 3rd anniversary of the birth of Bangladesh, to "join in the task of nation building" and that among those released were former cabinet ministers under the last Pakistani governor, members of the Central Peace Committee, members of the Peace and Welfare Council and members of suspected parties such as Jamaat e Islami, Muslim League, PDP and Nizam e Islam. ${ }^{72}$

While the amnesty did not apply to those charged with murder, rape or arson, apparently a large number of persons falling into this category, including prominent collaborators, were also released. ${ }^{73}$

The 1972 Collaborator's Act was repealed in 1975 by President Ziaur Rahman. ${ }^{74}$

\section{THE INTERNATIONAL CRIMES (TRIBUNALS) ACT $1973^{75}$}

The 1973 Act was adopted to provide for the detention, prosecution and punishment of "any person irrespective of his nationality who, being a member of any armed defence or auxiliary forces commits or has committed in the territory of Bangladesh, whether before or after the commencement of this act" any of the listed acts.

I shall be discussing the Act, as amended, in detail in the following section. But as a brief prelude to that, some introduction is necessary. The Act provided for establishment of "a tribunal" with jurisdiction over crimes against peace, crimes against humanity, war crimes, "violation of any humanitarian rules applicable in armed conflicts laid out in the Geneva Conventions of 1949" and "any other crimes under international law". There was no scope for exercise of jurisdiction over crimes in domestic law, i.e. the regular criminal code.

\footnotetext{
${ }^{70}$ Reza, supra note 65 , at 57.

71 VAN SCHENDEL, supra note 2, at 172; Opposition Leader Sheikh Hasina's parliamentary speech given on 16 April 1992, supra note 28, at 139.

${ }^{72}$ Hossain, supra note 64, at 52-53.

73 REDRESS, supra note 69, at 27.

${ }^{74} \mathrm{Id}$.

75 The International Crimes (Tribunals) Act, Act No XIX of 1973 (1973) (Bangl.) [hereinafter International Crimes (Tribunals) Act 1973].
} 
The cases were to be tried by panels of two to four persons who were or were qualified as judges of the Supreme Court, High Court or General Court Martial, and were to be based in Dhaka but able to hold sittings at other locations as deemed fit. ${ }^{76}$ There was no provision for trial in absentia. Unlike the 1972 Collaborators Act, this Act did not follow regular rules of procedure and evidence and the court was empowered to adopt its own provisions.

Evidence was gathered and prosecutors appointed. 11,000 of the detainees originally held under the 1972 Collaborators Order, suspected of crimes to which the amnesty did not apply, were to have been tried under this law. ${ }^{77}$ All work on this issue came to an end with the assassination of Prime Minister Sheikh Mujibur Rahman and his family members on 15 August 1975 by forces aligned against the liberation movement. Four of the leading politicians held in detention in the Central Jail were murdered on 3 November 1975. The new regime repealed the 1972 Collaborators Order, stopped prosecutions and released all. Professor M. Shah Alam suggests that they may have simply omitted to repeal the 1973 Act, since no trials were yet held under that law, nor any commissions formed. ${ }^{78}$

\section{ANALYSIS OF THE INTERNATIONAL CRIMES (TRIBUNALS) ACT 1973 AS AMENDED ${ }^{79}$}

In Dhaka, one is repeatedly told that this 37 year old law was, at its time of adoption, the world's only such legislation and that it was progressive and cutting-edge. Because legal luminaries Professor Hans-Heinrich Jescheck and Professor Otto Triffterer, with other

\footnotetext{
${ }^{76}$ In the 2009 amendment, this has been changed to remove military judges. "Any person who is a Judge or is qualified to be a Judge, of the Supreme Court of Bangladesh, may be appointed as a Chairman or member of a Tribunal". It is not clear if there will be transparent mechanisms for the appointment and removal of judges or the assignment of cases. These are often ways by which States exert undue influence over proceedings.

${ }^{77}$ Notes of the Presentation of AVM (Red.) A.K. Khandker, Chairman of Sector Commanders Forum, a presentation at the International Conference on Genocide, Truth and Justice, Dhaka, Bangladesh, Mar. 1-2, 2008, Conference ProceEdings, 6 (2008).

${ }^{78}$ Email from M. Shah Alam, Professor of the University of Chittagong (Sept. 5, 2009) (on file with the author).

${ }^{79}$ The International Crimes (Tribunals) Act 1973 as amended by the International Crimes (Tribunals) (Amendment) Act 2009 (2009) (Bangl.) [hereinafter International Crimes (Tribunals) Act As Amended].
} 
international lawyers from the International Commission of Jurists, contributed towards a process that was ultimately shepherded by Bangladesh's own outstanding Dr. Kamal Hossain, one is told that this law is unassailable. ${ }^{80}$ They say it has withstood the test of time and does not need substantial amendment. Those involved in the efforts to secure accountability speak with an emotional attachment to this law, seeing it as some kind of golden international standard and link to a glorious past that needs to be preserved.

That Bangladesh chose to adopt such a law in 1973 is indeed remarkable and admirable. It is true that, like the earlier Israeli Nazis and Nazi Collaborators (Punishment) Law of $1950,{ }^{81}$ this would have been a progressive law for its time. Improvements are what the international justice movement strives for as part of the overall quest: the tribunals set up under Control Council Law No. $10^{82}$ were already an improvement on Nuremberg. The International Crimes (Tribunals) Act 1973 contained some of the fair trial and due process rights required by the not-yet-in-force International Covenant on Civil and Political Rights ${ }^{83}$ and it was certainly framed by a deep understanding of the criminal justice process and international criminal law. Certain provisions, in this common law legislation, also seem to bear the mark of the continental lawyer anxious to streamline the lengthy adversarial process and get around its notoriously cumbersome rules of evidence.

The law is also 37 years out of date, and contains some provisions that were actually controversial at that time, such as war crimes in non-international armed conflict. As would be the case today, few, if

\footnotetext{
${ }^{80}$ The making of the law is recounted in WALI-UR RAHMAN, A BRIEF HISTORY OF THE FRAMING OF THE INTERNATIONAL CRIMES (TRIBUNALS) ACT 1973 (undated). The Ambassador relates the efforts of the Bangladesh Institute of Law and International Affairs, and his trips around Europe in consultation with various international lawyers.

${ }^{81}$ Nazis and Nazi Collaborators (Punishment) Law 5710-1950, 57 Sefer Ha-Hukim 154 (Isr.), as quoted in Attorney General of the Government of Israel v. Eichmann 36 I.L.R. 5, 7-8, 30 est. seq. (Isr. DC 1961) [hereinafter Eichmann District Court Judgement]. The Supreme Court affirmed the decision of the District Court in Attorney General of the Government of Israel v. Eichmann 36 I.L.R. 277 (Isr. S. Ct. 1962) [hereinafter Eichmann Supreme Court Judgement].

${ }^{82}$ Control Council Law No. 10, Punishment of Persons Guilty of War Crimes, Crimes Against Peace and Against Humanity, Dec. 20, 1945 (1946) 3 Official Gazette Control Council for Germany 50-55 [hereinafter Control Council Law No. 10].

${ }^{83}$ International Covenant on Civil and Political Rights, Dec. 16, 1966, 999 U.N.T.S. 171 (entered into force Mar. 23, 1976, Bangladesh acceded on Sept. 6, 2000) [hereinafter ICCPR].
} 
any, international lawyers would have seriously claimed that aggression (crimes against peace) could be committed in a war of secession. It seems unwise to have excluded recourse to the positive domestic penal laws that applied at the time of the crimes, and which had in fact been exclusively used in the 1972 Collaborators Act. In Cambodia, the United Nations insisted on the inclusion of the-then applicable domestic penal provisions in order to forestall any problems with retroactivity; the underlying domestic law has also been preserved in the relevant East Timor and Sierra Leone laws. These domestic law provisions are in fact being used in litigation, alongside the international ones. The failure to use it in Bangladesh's 1973 legislation leaves a vacuum in the instances where there are significant problems with using particular crimes as defined. Then, the international human rights law of today imposes far greater demands on a process of accountability than it did in 1973. Our understanding of international criminal law has been immeasurably refined in the last 2 decades, and legal work done on historic crimes of the 1970s in situations such as in Cambodia, East Timor and Latin America takes us well beyond the speculation about the state of customary international law in 1971 that was to some extent made into law in the form of the International Crimes (Tribunals) Act 1973. While there are concerns that can - and must be - validly raised about this law on the basis of the principles of specificity and nullum crimen sine lege, we need also to remember that they protect persons who reasonably believed that their conduct was lawful from retroactive criminalisation of their conduct, and will not protect those who knew that they were committing a crime from being convicted of that crime under a subsequent formulation. ${ }^{84}$ There may sometimes have to be recourse to domestic law for the purpose of establishing that the accused could have known that the offence in question or the offence committed in the way charged in the indictment was prohibited and punishable. ${ }^{85}$ Such considerations could have enriched and improved the Bangladeshi law in the amendments of 2009, in a way that is consistent with the overarching principle of legality.

${ }^{84}$ Prosecutor v. Stakić, Case No. IT-97-24-A, Appeal Judgement, ๆ 6 (Mar. 22, 2006) [hereinafter Stakić Appeal Judgement].

${ }^{85}$ Prosecutor v. Milutinović et al., Case No. IT-99-37-AR72, Decision on Dragoljub Odjanić's Motion Challenging Jurisdiction - Joint Criminal Enterprise, ๆ 40 (May 21, 2003). 
When it was clear that the government was going to proceed with a domestic tribunal under the 1973 Act, ${ }^{86}$ the Bangladesh Law Commission and Human Rights Watch made recommendations for amendment to this law to allow it to meet basic international standards. ${ }^{87}$ Unfortunately, the government chose only to tinker with the law, making a few changes that were necessary, but leaving aside the more substantial issues of legitimate and pressing concern. One is drawn to recall Indonesia and the process of its adoption of the unsatisfactory domestic legislation for the Human Rights Court that would eventually try the East Timor, Tanjung Priok and Abepura crimes against humanity cases in a purely domestic setting. There too, the State ignored the advice of experts. The unacceptably low quality of proceedings and outcome, recognised internationally as a 'sham', provided further injustice to the victims who had demanded accountability and justice. ${ }^{88}$ It may well be, as some have pointed out, that this charade was actually the officially desired state of affairs.

In the following section, I will address issues that remain of concern and which really do need to be addressed if this process is to become one that is worthy of the vision that accompanied the law's

${ }^{86}$ It is not clear that the government of Bangladesh was ever provided with detailed expert advice on the different forms of accountability mechanism that could be used. But, from discussions, it appears that the government considers an ad hoc court as being out of the question because of the objections of Pakistan and its allies in the Organisation of Islamic Conference. In particular, it seems that Saudi Arabia, with its large number of Bangladeshi migrant workers contributing to the economy of Bangladesh, exerts an undue influence on the decisions that are taken in this matter. I have personally observed a deep resistance to the idea of introducing some international judges, prosecutors and investigators into the system in an effort to diffuse the politicisation, strengthen capacity and assist with the enormous tasks. Unlike other countries that have specifically asked for international participation, such as Sierra Leone, Lebanon and Cambodia, in Bangladesh even suggestions to consider a role for direct international participation are treated as affronts to national dignity and sovereignty. When one objectively considers the entirety of the situation, including the reports about the state of the criminal justice system, the budgetary requirements and the complex legal issues examined in this paper, an internationalised process really does seem to be the best option.

${ }^{87}$ See Human Rights Watch, Letter to Prime Minister Sheikh Hasina Re: International Crimes (Tribunals) Act, 8 July 2009, http://www.hrw.org/en/news/2009/ 07/08/letter-prime-minister-sheikh-hasina-re-international-crimes-tribunals-act (last visited Aug. 30 2009). It is not known why Human Rights Watch called for the ICC definitions to be used, rather than the law that was actually applicable in 1971.

${ }^{88}$ See Suzannah Linton, Accounting for Atrocities in Indonesia, X SING. Y. B. INT'L L. 199-203 (2006) (for a detailed assessment of the process). 
adoption, and the many years of effort to find accountability and justice for the terrible sufferings and sacrifices of 1971.

\subsection{Relationship with Domestic Law}

The International Crimes (Tribunals) Act 1973 As Amended is not a standalone act, as it refers to several other laws, such as the Army Act 1952 and the Air Force Act 1953. However, the underlying criminal procedure and evidentiary rules are ousted through Section 23, which provides that the provisions of the Criminal Procedure Code 1898, ${ }^{89}$ and the Evidence Act, $1872^{90}$ shall not apply in any proceedings under this Act. It goes on, in Section 26, to provide that the provisions of this Act shall have effect notwithstanding anything inconsistent therewith contained in any other law for the time being in force. This normally does not refer to the Constitution, for all laws in Bangladesh are to be subject to the Constitution, ${ }^{91}$ but as will be discussed later, this law comes in for special treatment in the amended Constitution. There will obviously have to be detailed rules of procedure and evidence that are developed, setting out also the interplay with other domestic laws in Bangladesh and requiring the support of the underlying system, including over matters such as detention, subpoenas, witness summons, seizure of evidence, exhumations, forensics, international warrants of arrest, etc.

Also to be resolved will be the relationship of prosecutions brought under the International Crimes (Tribunals) Act 1973 As Amended, and the amnesties and pardons to persons accused of lesser crimes under the general amnesty granted by President Mujibur. Persons were released - whether convicted or pending trial pursuant to the 1972 Collaborators Act - and all proceedings, investigations and enquiries against others under this legislation were dropped. Those not benefitting from this clemency were those convicted for or charged with or alleged to have committed the more serious crimes under the Penal Code, such as murder, culpable homicide not

\footnotetext{
${ }^{89}$ Code of Criminal Procedure 1989, Act V of 1898 (Bangl.).

${ }^{90}$ Evidence Act, Act I of 1872 (Bangl.).

${ }^{91}$ See constitution of the PeOple's Republic of BANGLAdesh, Section 26 :
}

(1) All existing law inconsistent with the provisions of this Part shall, to the extent of such inconsistency, become void on the commencement of this Constitution. (2) The State shall not make any law inconsistent with any provisions of this Part, and any law so made shall, to the extent of such inconsistency, be void. 
amounting to murder, rape, mischief by way of fire or explosive, mischief by fire or explosive substance with intent to destroy houses and mischief by way of fire of explosive substance to any vessel. All from this latter category did in fact benefit from de facto amnesty and were released after the assassination of Sheikh Mujibur in 1975.

The 1968 Convention on the Non-Applicability of Statutory Limitations to War Crimes and Crimes Against Humanity ${ }^{92}$ provides that no statutory limitation shall apply to war crimes ${ }^{93}$ and crimes against humanity (including genocide and "eviction by armed attack or occupation and inhuman acts resulting from the policy of apartheid" $)^{94}$ irrespective of the date of their commission. But, Pakistan was not a party, and to this day, neither is Bangladesh. It is unclear whether this is sufficiently reflected in State practice and opinio juris to be treated as customary international law. ${ }^{95}$

The issue of retroactivity is obviously relevant. It is now well established in international law that the mere fact of prosecuting international crimes by way of a law adopted after the commission of the crimes is not necessarily a violation of the fundamental prohibition against retroactive prosecutions. This was enshrined in Article 11(2) of the Universal Declaration of Human Rights; ${ }^{96}$ the Nurem-

${ }^{92}$ Convention on the Non-Applicability of Statutory Limitations to War Crimes and Crimes Against Humanity, Nov. 26 1968, G.A. Res. 2391 (XXIII) U.N. Doc. A/ 7218 (Nov, 25, 1968) (entered into force Nov. 11 1970).

93 The provision only applies to war crimes as they are defined in the Charter of the International Military Tribunal (Annex to the Agreement for the prosecution and punishment of the major war criminals of the European Axis, Aug. 8, 1945 [hereinafter The London Agreement]), 82 U.N.T.S 279 (Aug. 8, 1945) [hereinafter Charter of the IMT Nuremburg or IMT Nuremburg] and as confirmed by G.A. Res. 3(I), U.N. Doc. A/RES/3(I) (Feb. 13, 1946) and UNGA Res 95(I), U.N. Doc. A/ RES/95(I) (Dec. 11, 1946).

94 The provision only applies to crimes against humanity whether committed in time of war or in time of peace as they are defined in the Charter of the IMT Nuremberg, supra note 93, eviction by armed attack or occupation and inhuman acts resulting from the policy of apartheid, and the crime of genocide as defined in the Genocide Convention, supra note 1 , even if such acts do not constitute a violation of the domestic law of the country in which they were committed.

${ }^{95}$ But in 2001, Kok argued that this had crystallised into a rule of customary international law. See RUTH A KOK, STATUTORY LIMITATIONS IN INTERNATIONAL CRIMINAL LAW 308 (2007).

${ }^{96}$ Universal Declaration of Human Rights, G.A. Res. 217A, at 71, U.N. GAOR, 3rd Sess., 1st plen. mtg., U.N. Doc. A/810 (Dec. 12, 1948). 
berg Principles, ${ }^{97}$ and is reflected with some variation in the major regional and universal human rights treaties, including the ICCPR, to which Bangladesh acceded on 6 September 2000. Article 15 of the ICCPR reads as follows:

1. No one shall be held guilty of any criminal offence on account of any act or omission which did not constitute a criminal offence, under national or international law, at the time when it was committed. Nor shall a heavier penalty be imposed than the one that was applicable at the time when the criminal offence was committed. If, subsequent to the commission of the offence, provision is made by law for the imposition of the lighter penalty, the offender shall benefit thereby.

2. Nothing in this article shall prejudice the trial and punishment of any person for any act or omission which, at the time when it was committed, was criminal according to the general principles of law recognized by the community of nations.

So, prosecution of genocide, crimes against humanity and other international crimes is not a problem using a law passed after the acts were committed, provided that the law is drafted in a way that reflects the state of international law at that time, which must have considered the acts as criminal. Prosecution and punishment in accordance with Article 15 of the ICCPR requires that it is not just that the acts or omissions were prohibited in international law, but that the acts or omissions prohibited by international law resulted in individual criminal responsibility under international law at that point in time. We see the rule articulated in the following terms in Article 22(1) of the ICC Statute: 98 "a person shall not be held criminally responsible unless the conduct in question was, at the time of the commission, a crime within the jurisdiction of the court". The ICTY's Stakic case reminds us that this rule exists to protect persons who reasonably believed that their conduct was lawful from retroactive criminalisation of their conduct, and will not protect those who knew that they were committing a crime from being convicted of that crime under a subsequent formulation. ${ }^{99}$

There are a number of problems of retroactivity with the International Crimes (Tribunals) Act 1973 As Amended, notably the

\footnotetext{
${ }^{97}$ U.N. International Law Commission [ILC], Principles of International Law Recognised in the Charter of the Nurnberg Tribunal and in the Judgement of the Tribunal, U.N. Doc. A/1316 Part III, reprinted in [1950] II Y.B. Int'l L. Comm'n 364 [hereinafter ILC Nuremburg Principles].

${ }^{98}$ Rome Statute of the International Criminal Court, art 22(1), Jul. 17, 1998, 2187

U.N.T.S. 90 (entered into force Jul. 1, 2002) [hereinafter ICC Statute].

99 Stakić Appeal Judgement, supra note 84, ๆ 6.
} 
possibility of prosecuting crimes committed in non-international armed conflict as war crimes in 1971, and problems of legality, such as prosecuting "any crimes under international law" and "any humanitarian rules applicable in armed conflicts laid out in the Geneva Conventions of 1949" (even today such prosecutions would be a problem) and convicting persons on the basis of never-beforeseen notions of criminality said by some to reflect the Yamashita principle. There are other problems, such as the definition of genocide that expands on the Genocide Convention, and the ever controversial notion of crimes against peace. It is pertinent to note here that in recommending the Draft Statute of the ICTY, the Secretary-General of the United Nations underscored the importance that had been given to ensuring that the subject matter jurisdiction of the tribunals must apply customary international law at the time. ${ }^{100}$ While it is very clear that a skilled and serious attempt was made in defining the crimes in the International Crimes (Tribunals) Act 1973, it seems that the formulations used did not, in several instances, actually reflect the state of customary international law at the time of the commission of the offences.

Professor Jescheck acknowledged the "relaxed attitudes put forward by the IMT", ${ }^{101}$ but according to one of the local drafters of the law, the Nuremberg process, the Principles that emerged and customary international law were enough to guarantee the legitimacy of the legislation in 1973. ${ }^{102}$ The Bangladesh Constitution throws a spanner in the works: it provides, inter alia, in Section 35, that "[n]o person shall be convicted of any offence except for violation of

100 The Secretary-General, Report of the Secretary-General Pursuant to Paragraph 2 of Security Council Resolution 808, $\uparrow$ 34, U.N. Doc. S/25704, reprinted in 32 I.L.M. 1159 [hereinafter Report of the UNSG under UNSC Res 808]:

In the view of the Secretary-General, the application of the principle nullum crimen sine lege requires that the international tribunal should apply rules of international humanitarian law which are beyond any doubt part of customary law so that the problem of adherence of some but not all States to specific conventions does not arise. This would appear to be particularly important in the context of an international tribunal prosecuting persons responsible for serious violations of international humanitarian law.

${ }^{101}$ Hans-Heinrich Jescheck, The General Principles of International Criminal Law Set Out in Nuremberg, as Mirrored in the ICC Statute, 2 J. INT'L J. CRIM. JUSTICE 38, 42 (2004).

${ }^{102}$ M. Amir-Ul Islam, Bringing the Perpetrators of Genocide to Justice, a paper presented at the International Conference on Genocide, Truth and Justice, Dhaka, Bangladesh, Mar. 1-2, 2008, CONFERENCE PROCEEDINGS, 3 (2008). 
a law in force at the time of the commission of the act charged as an offence". The earlier 1972 Collaborators Act, pursuant to Article 47 of the Constitution, was listed on a schedule of legislation which could not be challenged as unconstitutional. ${ }^{103}$ The drafters of the International Crimes (Tribunals) Act 1973 As Amended acted to forestall any challenges to that act, and the Legislature obliged. In the words of one of those involved, in order

to bury any doubt or debate, we brought in the First Amendment to our Constitution...This was to remove any doubt whatsoever or eradicate any foreseeable controversy in the future as to its applicability in identifying as well as investigating and trying such offence whenever and wherever it is committed. ${ }^{104}$

In Dhaka today, the position is taken that there can be no problem with retroactivity arising from the use of the 1973 Act because the Constitution provides that nothing done under the act can ever be unconstitutional. They refer to the amendment to the Constitution, adopted in tandem with the 1973 Act, resulting in Section 47(3). ${ }^{105}$ This provides that:

Notwithstanding anything contained in this Constitution, no law nor any provision thereof providing for detention, prosecution or punishment of any person, who is a member of any armed or defence or auxiliary forces or who is a prisoner of war, for genocide, crimes against humanity or war crimes and other crimes under international law shall be deemed void or unlawful, or ever to have become void or unlawful, on the ground that such law or provision of any such law is inconsistent with, or repugnant to, any of the provisions of this Constitution.

Bangladeshis are justly proud of their constitution, the rights it enshrines and the struggle for liberation from which it emerged. Each country has its own principles of public law, and each constitution its own internal logic and structure. But Parliament is usually supreme in a Westminster style democracy. The German precedent shows how unchecked Parliamentary supremacy can lead to ruin of a nation; that even popularly endorsed power must not be abused. Bangladeshi constitutional law expert Mahmudul Islam admits that Bangladesh too has had its Constitution "turned into a document permitting

\footnotetext{
103 See constitution of the People's Republic of Bangladesh, First Schedule.

104 ISLAM, supra note 102 , at 3.

105 The provision was inserted by the Constitution (First Amendment) Act 1973, Act XV of 1973 (Bangl.), Section 2 (taking effect on 15 July 1973).
} 
autocratic rule". ${ }^{106}$ If one adheres to the doctrine of positivism stricto sensu, it may, in the extreme, lead to the conclusion that once law is properly passed, it is valid and there can be no more questions about the law's validity, no challenge to the legitimacy of the law. The record shows how the IMT Nuremberg dismissed the defence of official acts required by law by way of technicality. ${ }^{107}$ It is not just about formal validity of law, as H.L.A. Hart wrote in an oft quoted passage in The Concept of Law,

What surely is most needed in order to make men clear sighted in confronting the official abuse of power, is that they should preserve the sense that the certification of something as legally valid is not conclusive of the question of obedience, and that, however great the aura of majesty or authority which the official system may have, its demands must in the end be submitted to a moral scrutiny. This sense, that there is something outside the official system, by reference to which in the last resort the individual must solve his problems of obedience, is surely more likely to be kept alive among those who are accustomed to think that rules of law may be iniquitous, than among who think that nothing iniquitous can anywhere have the status of law. ${ }^{108}$

The classic Hart-Fuller debate on the relationship between morality, justice and the law is of course here relevant ${ }^{109}$ as is Germany's struggle with morally controversial normative provisions, whether under the Nazis or in East Germany (the Border Guards cases). Resolution of the challenge of Bangladesh's problematic constitutional amendment

106 ISLAM, supra note 3 , at 13.

107 United States of America v. Josef Altstoetter, VI Law Reports of Trials of War Criminals 1, 49 (U.S.A. Military Tribunal, 1949):

It is true, as defendants contend, that German courts under the Third Reich were required to follow German law (i.e. the expressed will of Hitler) even when it was contrary to international law. But no such limitation can be applied to this Tribunal. Here we have the paramount substantive law, plus a Tribunal authorized and required to apply it notwithstanding the inconsistent provisions of German local law. The very essence of the prosecution case is that the laws, the Hitler decrees and the draconic, corrupt and perverted Nazi judicial system themselves constituted the substance of war crimes and crimes against humanity and that participation in the enactment and enforcement of them amounts to a complicity in crime.

108 HERBERT L. A. HART, THE CONCEPT OF LAW 206 (1st ed., 1961) (emphasis added).

${ }^{109}$ See H.L.A. Hart, Positivism and the Separation of Law and Morals, 71(4) HARV. L. REV. 539 (1958) and Lon L. Fuller, Positivism and Fidelity to Law - A Reply to Professor Hart, 71(4) HARV. L. REV 630 (1958). 
could certainly be aided with consideration of Gustav Radbruch's seminal 1946 work on "Gesetzliches Unrecht und übergesetzliches Recht." ${ }^{110}$ In this, he famously considered the application of Nazi laws, and argued that in resolving the conflict of legal certainty and justice, preference should be given to the duly enacted law and secured by state power as it is, even when it is unjust and fails to benefit the people. The exception would be if the conflict with justice reaches so intolerable a level that the statute becomes effectively 'false law'; in such a case, it must yield to justice. Radbruch rejected the positivist argument that one can legislate anything, even the manifest immorality of the National Socialist ilk, into binding law; for him, statutory rules that reach a level of extreme injustice cease to be law. He argued that "Where there is not even an attempt at justice, where equality, the core of justice, is deliberately betrayed in the issuance of positive law, then the statute is not merely 'flawed law', it lacks completely the very nature of law'. ${ }^{111}$

How then should Section 47(3) of the Bangladeshi Constitution be viewed? There are two problems that seem to arise. Firstly, principles of fairness, equality and responsible use of power are called into question when a legislature adopts laws and make changes to the constitution that are wholly in favour of the government, representing one side to a conflict, and which are to the detriment of persons belonging to the other side in that conflict in the sense of blocking off their ability to rely on the highest law in the land in the protection of fundamental rights. This raises the fundamental question of fairness, and whether the constitutionality of the amendment can be challenged. Richard Albert suggests this sort of approach is tantamount to asking whether the Bible is unbiblical ${ }^{112}$ - or, in our context, a question that goes to Bangladesh's constitutional order. In addition to the possibilities already mentioned, e.g. the Radbruch formulation, one approach that could be tried is the "basic structure doctrine; or 'substantive model', that attempts to limit the powers of a Parliament in amending in a constitution. Albert has noted that the Supreme Courts in three countries have adopted this approach: India, Germany and South Africa. ${ }^{113}$ India's Supreme Court has held that its Parliament, in exercise of the power of amendment granted by the

${ }^{110}$ See Gustav Radbruch, Statutory Lawlessness and Supra-Statutory Law, translated by Bonnie Litschewski Paulson \& Stanley L. Paulson into English and republished in 26(1) Oxford J. Legal Stud. 111 (2006).

${ }^{111}$ Id. p.7.

112 Richard Albert, Nonconstitutional Amendments 22 CAN. J. L. \& JURIS. 5, 5 (2009).

${ }^{113} I d$. 
constitution, cannot alter its basic structure or features. ${ }^{114}$ One is drawn to recall here, Indira Gandhi's 42nd amendment to the Indian Constitution: "No amendment... shall be called into question in any court on any ground" which was invalidated by the Supreme Court on grounds of negation of the right of equality and in contravention to the basic principles of the constitution. ${ }^{115}$ Bangladesh's equivalent case was Anwar Hossain Chowdhury v Bangladesh, or the "8th Amendment case', with the Appellate Division finding that Parliament could not, under its powers of amendment, change the constitution in a way that altered its basic structure or features. ${ }^{116}$ The basic structures and features that cannot be altered include: independence of the judiciary and fundamental rights, as well as rule of law. ${ }^{117}$

Nobody charged under the International Crimes (Tribunals) Act 1973 As Amended will be able to challenge the provisions of the Act as violating fundamental rights protected by the Constitution (in particular, Section 31 (Right to protection of law), Section 35 (Protection in respect of trial and punishment) and Section 44 (Enforcement of fundamental rights). Nobody will be able to challenge, on constitutional grounds, the independence of the judiciary. Access to this critical remedy is barred. From the perspective of international

\footnotetext{
${ }^{114}$ Keshavandanda v, Kerala, A.I.R. 1973 S.C. 1461.

${ }^{115}$ Minerva Mills v. Union of India, A.I.R. 1980 S.C. 1789. For a review of the Indian cases on 'unconstitutional amendments', See Gary Jeffrey Jacobsohn, An unconstitutional constitution? A comparative perspective 4 INT’L J. CONST. L. 460 (2006). Jacobsohn also cites from a 1951 German Supreme Court case, the Southwest case, where the court expressly invoked German's past to affirm that never again would formal legal means be used to legalise a totalitarian regime:
}

That a constitutional provision itself may be null and void, is not conceptually impossible just because it is part of the Constitution. There are constitutional provisions that are so fundamental and to such an extent an expression of a law that precedes even the constitution that they also bind the framer of the constitution, and other constitutional provisions that do not rank so high may be null and void, because they contravene these principles (at 447, footnote 58).For a discussion in the context of American constitutional law, see Vincent Samar, Can a Constitutional Amendment be Unconstitutional? 33 OKLA. CITY U. L. REV. 667 (2008).

${ }^{116}$ Anwar Hossain Chowdhury v. Bangladesh B.D.L. (Spl) 1, 41 DRF (AD) 165 (Bangl., S. Ct. Appellate Div. 1989). See also ISLAm, supra note 3, at 393-408 (discussing the case).

${ }^{117}$ Anwar Hossain Chowdhury v. Bangladesh, supra note 113, ฯ 377, 443 (Shahabuddin Ahmed J. and M.H. Rahman J.). 
human rights law, there was no emergency in 1973, and there certainly is no emergency today warranting such deviation from the equal protection of the law or fair trial with due process. This infringement of fundamental rights is not necessary and is disproportionate. In addition, the aim of the changes itself seems also problematic. The ousting of the protections of the usual criminal procedure was intended to overcome prosecutorial difficulties in building cases, and Section 47(3) of the Constitution was, it is no secret, intended to forestall challenges to the International Crimes (Tribunals) Act 1973. ${ }^{118}$ Thus, the whole scheme seems intended to give an almost free hand to the government, and then block off any constitutionally based challenges to the law or any provisions in it. And, the Constitutional provisions that are most relevant are independence of the judiciary and fundamental rights, as well as rule of law. In Anwar Hossain Chowdhury v Bangladesh, Judge Rahman also pointed out that

...if any amendment causes any serious impairment of the powers and the functions of the Supreme Court the makers of the Constitution devised as the kingpin for securing the rule of law to all citizens, then the validity of such an amendment will be examined on the touchstone of the Preamble. ${ }^{119}$

Is there then not a major problem with Section 47(3) of the Constitution, in light of the 8th Amendment Case?

Secondly, if we look at Section 47(3) of the Constitution in isolation, one does get the impression that this cutting off of constitutional remedies may have been targeting of the 'other side', and was contrary to the spirit of the Constitution as a whole. However, it cannot be seen in isolation Seen in context of the entire provision, it is in substance a mere addition to a raft of legislation that was excepted in the schedule referred to, ranging from the Bangladesh Bank Order 1972 to the Bangladesh Jute Corporation Order 1972 and the 1972

${ }^{118}$ See also Islam, supra note 102 , at 3.

${ }^{119} I d$., 391. See also CONSTitution OF THE PEOPLE'S REPUBLIC OF BANGLADESH, preamble:

that it should be a fundamental aim of the State to realize through the democratic process a socialist society, free from exploitation - a society in which the rule law, fundamental human rights and freedom, equality and justice, political, economic and social, will be secured for all citizens (emphasis added). 
Collaborators Order. Even if it is correct in terms of formal constitutional law, given the degree of legitimate constitutional challenges that could be made under the International Crimes (Tribunals) Act 1973 As Amended, blocking off that avenue is a matter that, if trials proceed, is likely to be a matter for the concern of the Human Rights Committee in reviewing Bangladesh's compliance with the ICCPR. It could also be questioned by the Committee in reviewing compliance with CERD. ${ }^{120}$ These issues are examined in the next section.

A final note is that the constitutional amendment only applies to "any person, who is a member of any armed or defence or auxiliary forces or who is a prisoner of war" accused of genocide, crimes against humanity or war crimes and other international crimes. It does not quite track the language of the International Crimes (Tribunals) Act 1973 As Amended. A civilian who was not one of the above would not be covered by the said provision - this raises questions in relation to the Central Peace Committee and the Peace and Welfare Council, which were civilian organisations.

\subsection{Relationship with International Law and Comparative Approaches}

Bangladesh's legal system follows English common law. Treaties and other international conventions require incorporation into domestic law by an act of Parliament in order to be applied. ${ }^{121}$ Bangladesh and others v. Sombon Asavhan established that where there is municipal law on an international subject the national court's function is to "enforce the municipal law within the plain meaning of the stat-

\footnotetext{
${ }^{120}$ Bangladesh acceded to the CERD, supra note 1, on Jun. 11, 1979.

${ }^{121}$ For a classical statement of the position in English law, See J.H. Rayner (Mincing Lane) Ltd v. Department of Trade and Industry Ltd [1990] 2 A.C. 418, 500 (H.L.) [hereinafter The International Tin Council case] (Lord Oliver):
}

A treaty is not part of English law unless and until it has been incorporated into the law by legislation. So far as individuals are concerned, it is res inter alios act from which they cannot derive rights and by which they cannot be deprived of rights or subject to obligations. 
ute". ${ }^{122}$ Customary international law is directly applicable without such formal incorporation, it being already part of the common law and the law of the land (although this is subject to not conflicting with an act of Parliament). ${ }^{123}$ The Bangladesh Constitution contains an incomplete reference, in Article 145(A) to international treaties; it simply covers procedure for submitting treaties before Parliament. ${ }^{124}$ There is nothing on the status of treaties or customary international law. Mr. Justice Chowdhury has presented the approach taken by the Bangladeshi courts in the following terms:

True it is that the Universal Human Rights norms, whether given in the Universal Declaration, or in the Covenants, are not directly enforceable in national courts. But if their provisions are incorporated into the domestic law, they are enforceable in national courts. The local laws, both constitutional and statutory, are not always in consonance with the norms contained in international human rights instruments. The national court should not, I feel, straightway ignore the international obligations, which a country undertakes. If the domestic laws are not clear enough or there is nothing therein the national courts should draw upon the principles incorporated in the international instruments. But in the cases where the domestic laws are clear and inconsistent with the international obligations of the state concerned, courts will be obliged to respect the national law, but shall draw the attention of the law makers to such inconsistencies. ${ }^{125}$

In the matter of the prosecution of international crimes, the International Crimes (Tribunals) Act As Amended will probably have to be treated as the primary source of law for any tribunal that is created to take jurisdiction. But, by referencing the enumerated international crimes, the body of laws on which these crimes have been developed in customary and treaty law is probably also to be treated as a source of law. ${ }^{126}$ In the matter of the incorporation of treaties by the law,

${ }^{122}$ See Bangladesh and others v. Sombon Asavhan (1980) 32 D.L.R. 198, 201 (Bangl., S. Ct. Appellate Div.); Bangladesh v. Unimarine SA Panama (1997) 29 D.L.R. 252 (Bangl., S. Ct.). See also M. SHAH Alam, ENFORCEMENT OF INTERNATIONAL HUMAN RIGHTS LAW BY DOMESTIC COURTS 102 (2007) (discussing these cases).

${ }^{123}$ For the traditional common law position, see 4 WILLIAM BLACKSTONE, COMMENTARIES ON THE LAWS OF ENGLAND 67 (15th ed., 1809) ("the law of nations, in its fullest extent, was part of the law of the land"). See also Trendtex Trading Corporation v. Central Bank of Nigeria [1977] 2 W.L.R. 356 (C.A.).

124 ALAM, supra note 122, at 118.

125 See Hussain Muhammad Ershad v. Bangladesh and others (2001) 21 B.L.D. (AD) 69 (Bangl.). See also AlAm, supra note 122, at 108 (discussing the case).

${ }^{126}$ ALAM, supra note 122, at 110. Alam has also written that 
this seems to be incorporation by reference only, since incorporation was not formally done by way of inclusion in an annexed schedule (the only international conventions specifically referred are the Geneva Conventions of 1949). ${ }^{127}$ Of course, some unincorporated treaties, such as the Genocide Convention and the Regulations annexed to Hague Convention IV, ${ }^{128}$ will be declaratory of customary international law. According to Professor M. Shah Alam, Bangladeshi judges are not enthusiasts either of referring to or applying unincorporated treaties. ${ }^{129}$ Others have commented that the Bangladeshi courts have only been prepared to observe that an unincorporated treaty "could be recognized upon ratification", without elaborating on how it could be so done. ${ }^{130}$ There is also an argument that reference to English jurisprudence may amount to some implicit approval of the English judicial trend of using unincorporated conventions for a plurality of purposes, however, given the rather conservative attitude of the Bangladeshi courts, it remains uncertain whether this argument is actually true. ${ }^{131}$ One thing is however certain: the Constitution is the supreme law of the land. International laws therefore, will only be applied to the extent that they comply.

The maxim jura novit curia aside, is it going to be possible for the Bangladeshi court to seek expert opinions, or amicus curiae briefs, on some of the complex matters of international criminal law that it is going to have to grapple with? Will the Bangladeshi tribunal interpret treaties in accordance with the Vienna Convention on the Law of

\section{Footnote 126 continued}

Even subscribing to the principle of primacy of domestic law vis-à-vis international law, it is possible to resort to vast potentials of international law by reading these norms into domestic law, or illuminating domestic law by international law or where domestic law are not clear by interpreting them in the light of international law, or where there is no relevant domestic law, by applying international law.

127 The Four Geneva Conventions of 1949, See supra note 1.

${ }^{128}$ Hague Convention (IV) Respecting the Laws and Customs of War on Land with annexed Regulations, Oct. 19, 1907 [1910] U.K.T.S. 9 [1907] Cmnd. 5030 [hereinafter Hague Convention IV].

129 ALAM, supra note 122, at 100, 102.

${ }^{130}$ See Ridwanul Hoque and Mostafa Mahmu Naser, The Judicial Invocation of International Human Rights Law in Bangladesh: questing a Better Approach 40 INDIAN J. INT'L L. 151, 180 (2006); ALAM, supra note 122, at 114.

131 ALAM, supra note 122, at 114 . 
Treaties, Articles $31-33$ of which are regarded as customary in nature? ${ }^{132}$ Here, guidance can also be derived from national practice $^{133}$ and other jurisdictions. ${ }^{134}$ Strict reading of the rules without understanding the humanitarian purposes and philosophy behind them can lead to unjust denial of legal protections to the vulnerable victims of conflict. Judge ad hoc Lauterpacht wisely counselled in the decision on the Application of the Convention on the Prevention and Punishment of the Crime of Genocide (Provisional Measures) that

[w] hile the demands of legal principle cannot be ignored, it has to be recalled that the rigid maintenance of principle is not an end in itself but the constructive application of law to the needs of the ultimate beneficiaries of the legal system, individuals, no less than the political structures in which they are organised. ${ }^{135}$

${ }^{132}$ Notwithstanding that to date, Bangladesh is not a party to the Convention. See Vienna Convention on the Law of Treaties, May 23, 1969, 1155 U.N.T.S. 331 (entered into force Jan. 27, 1980) [hereinafter VCLT]. Held to be customary in cases including: Application of the Convention on the Prevention and Punishment of the Crime of Genocide (Bosn. v. Serb.) (Judgement of Feb. 26, 2007), 160, available at http://www.icj-cij.org/docket/files/91/13685.pdf (last visited Aug. 30, 2009) [hereinafter Bosnia v. Serbia 2007 Judgement]; Legal Consequences of the Construction of a Wall, Advisory Opinion, 2004 I.C.J. Reports 136, 94 (Jul. 9) [hereinafter Wall Advisory Opinion]; Avena and Other Mexican Nationals (Mex. v. U.S.A.), 2004 I.C.J. Reports 128, 99 (Mar. 31); LaGrand (Ger. v. U.S.A.), 2001 I.C.J. Reports 466 (Jun. 27); Sovereignty over Pulau Ligitan and Pulau Sipdan (Indon. v. Malay.), 2002 I.C.J. Reports 625, 37 (Dec. 17); Appellate Body Report, United States Standards for Reformulated and Conventional Gasoline, 16-17, WT/DS2/AB/R (May 20, 1996) (For Article 31); Appellate Body Report, European Community - Customs Classification of Certain Computer Equipment, 104, WT/DS62/AB/R; WT/DS67/AB/ R; WT/DS68/AB/R (Jun. 5, 1998) (For Article 32).

${ }^{133}$ See ISLAM, supra note 3, at 32-47 (for an overview of Bangladeshi practices of statutory interpretation).

${ }^{134}$ See e.g. Fothergill v. Monarch Airlines [1981] A.C. 251, 281-282 (H.L.) (Lord Diplock):

The language of an international convention has not been chosen by an English Parliamentary draftsman. It is neither couched in the conventional English legislative idiom nor designed to be construed exclusively by English judges. It is addressed to a much wider and more varied judicial audience than is an Act of Parliament.... It should be interpreted as Lord Wilberforce put it... "unconstrained by technical rules of English law, or by English precedent, but on broad principles of general acceptance."

135 Application of the Convention on the Prevention and Punishment of the Crime of Genocide (Bosn. v. Serb.), 1993 I.C.J. Reports 408 (Provisional Measures Order of Apr. 8, 1993) (separate opinion of Judge ad hoc Lauterpacht). 
Trial Chambers at the ICTY have taken a teleological approach in dealing with the tricky issues of law in this field, some of which, it has to be said, are not sufficiently flexible to meet the reality of many of the situations faced. It is particularly so in the case of a prolonged occupation. An ICTY Trial Chamber in the Čelebići case ${ }^{136}$ called for a broad and principled approach to the application of the basic norms of the international law of armed conflict. It stressed that all of those individuals who took no active part in hostilities and yet found themselves engulfed in the horror and violence of war should not be denied the protection of humanitarian law (Geneva Convention IV in the particular case). ${ }^{137}$ This approach has also found favour with the ICTY Appeals Chamber in Tadic.. ${ }^{138}$

Common law judges are known for being somewhat reluctant to rule on matters of international law, seeing this body of law as being more about policy or foreign affairs. ${ }^{139}$ According to Professor M. Alam Shah, judges in Bangladesh tend to "shy away from any serious consideration of international law", including international instruments. ${ }^{140}$ How is the legal process to deal with the matter of the critical jurisprudence on international crimes since 1945? Reference to the enormous body of jurisprudence in this area, and careful handling of it to ensure respect for the principle of legality, is essential. But, can Bangladeshi courts refer to, and apply, the decisions of other domestic courts, international tribunals and sometimes international human rights courts and treaty monitoring bodies? The methodology will be challenging. Assuming the courts will be able to rely on and even directly apply international jurisprudence, will they follow an international law methodology or Bangladesh's common law tradition in these matters? For example, in international law, there is no doctrine of stare decisis; in common

${ }^{136}$ Prosecutor v. Zejnil Delalić, Zdravko Mucić, Hazim Delić and Esad Landzo, Case No. IT-96-21-T, Judgement, 275 (Nov. 16, 1998) [hereinafter Delalić et al. Trial Judgement or the Čelebići case].

${ }^{137} I d$.

${ }^{138}$ Prosecutor v. Tadić, Case No. IT-94-1-A, Appeal Judgement, 168 (Jul. 15, 1999) [hereinafter Tadić Appeal Judgement].

139 ROSALYN HIGGINS, PROBLEMS AND PROCESS: INTERNATIONAL LAW AND HOW WE USE IT 206-207 (1994). (The author argued that this reticence stems from a distinct legal culture, characterised by a lack of background in international law for among judges, and that this manifests itself in various ways, ranging from contempt for international law, to strenuous efforts not to decide points of international law but to locate the ratio decidendi on more familiar ground (emphasis added).)

140 ALAM, supra note 120, at 100, 102. 
law Bangladesh, this is a fundamental tenet of the legal approach. In view of these being foreign cases, logic suggests that a Bangladeshi tribunal, if it is allowed to consider such cases, will probably not be bound, but merely be guided in accordance with the persuasiveness of the particular decision. In taking on the monumental exercise of trying international crimes domestically, Bangladesh may find guidance in the approaches taken by Canadian, British and Australian courts in trying war crimes cases. ${ }^{141}$ These common law jurisdictions have, in the cases before them, had to have recourse to international law, particularly customary international law, which is notoriously difficult to ascertain.

As already indicated, there are likely to be problems with international treaty monitoring bodies. The reason these external bodies would have the power to examine the situation is that by becoming a party to the ICCPR ${ }^{142}$ and CERD ${ }^{143}$ Bangladesh has consented not just to abide by the treaties, but to external scrutiny. Pacta sunt servanda. The ICCPR is particularly relevant, given the ousting of the regular criminal procedure in the International Crimes (Tribunals) Act 1973 As Amended, and the amendment to the Constitution that expressly prohibits any challenges to the constitutionality of the International Crimes (Tribunals) Act $1973 .{ }^{144}$ This is borne out by reference to the Human Rights Committee's jurisprudence and in particular, its General Comment 32 on the right to equality before

${ }^{141}$ See the contribution of Gideon Boas to this Special Edition. Canada's present War Crimes Program was established in 1998, replacing an earlier programme of unsuccessful prosecutions, specifically the trial of Imre Finta, who was acquitted (see R v. Finta [1994] 1 S.C.R. 701 (Can.). The UK adopted its War Crimes Act in 1991, and has so far only tried one historic crime - the accused was convicted. (See R v. Anthony Sawoniuk [2000] 2 Cr. App. R. 220 (C.A.) (leave to appeal to the House of Lords rejected by both the Court of Appeal and House of Lords).) Australia has had a War Crimes Act since 1945, but amended it in 1988 (see Polyukhovic v. Commonwealth (1991) 172 C.L.R. 501 (Austl.)). See Gillian Triggs, Australia's War Crimes Trials: All Pity Choked, in THE LAW OF WAR CRIMES: NATIONAL AND INTERNATIONAL APPROACHES 123-150 (Timothy L.H. McCormack \& Gerry Simpson eds., 1997); Sharon A. Williams, Laudable Principles Lacking Application: The Prosecution of War Criminals in Canada, in THE LAW OF WAR CRIMES, above, at 151-170. See also Ian Bryan \& Peter Rowe, The role of evidence in war crimes trials: the common law and the Yugoslav tribunal 2 Y.B, INT'L HUMANITARIAN L. 307 (2006).

142 Bangladesh acceded on Sept., 6, 2000.

${ }^{143}$ Bangladesh acceded on Jun. 11, 1979.

${ }^{144}$ On a technical matter, the Constitution has not been amended to reflect the fact that the 1973 law has now been amended. 
courts and tribunals and to a fair trial. ${ }^{145}$ The setup in Bangladesh provides unequal application and protection of the law, and discriminatory access to challenge alleged violations of fundamental human rights as enshrined in the highest law of the land. The Human Rights Committee may well find Bangladesh to be in breach of other international obligations under the ICCPR. In addition to Article 14, Article 9(4) of the ICCPR would be particularly relevant: "Anyone who is deprived of his liberty by arrest or detention shall be entitled to take proceedings before a court, in order that that court may decide without delay on the lawfulness of his detention and order his release if the detention is not lawful." As I examine later in the section on Rules of Procedure and Evidence, there are no substantive rules governing arrest and detention under the International Crimes (Tribunals) Act 1973 As Amended. In any event, a complaint from a detained person, if based on the Constitutional's fundamental rights guarantees, is not permissible under Section 47(3) of the Constitution. This clearly creates a clash with Bangladesh's international obligations.

The ICCPR's Articles 9 on rights of liberty and 14 on equality before the law and due process are, as has been noted, critical. These have been authoritatively interpreted by the Human Right Committee, and these interpretations should not be dismissed on formalistic, technical grounds. Another concern is to do with rights such as the presumption of innocence, which the Human Rights Committee considers so critical as to be non-derogable. ${ }^{146}$ This right is impacted on by failure in the International Crimes (Tribunals) Act As Amended adequately to protect the subsidiary rights to silence and non-self-incrimination, given how the legislation tilts towards the extraction of confessions. One of the issues that may also arise is the regularity of the tribunal, for this is a 'special' tribunal in every way, down to the exclusion of the regular rules of procedure and evidence. The ICCPR requires that tribunals be established by law, which this one certainly is. The Human Rights Committee has not held 'special' tribunals to be unlawful, but has warned that "quite often the reason

${ }^{145}$ Human Rights Committee, General Comment No. 32 - Article 14: Right to equality before courts and tribunals and to a fair trial, U.N. Doc. CCPR/C/GC/32 (Aug. 23, 2007).

146 Note however, that the Human Rights Committee makes it clear that this is not the only right that is non-derogable. See Human Rights Committee, General Comment No. 29 - States of Emergency (Article 4), U.N. Doc. HRI/GEN/1/Rev.6 at 186; U.N. Doc. CCPR/C/21/Rev.1/Add.11 (Aug. 31, 2001) [hereinafter General Comment 29]. 
for the establishment of such courts is to enable exceptional procedures to be applied which do not comply with normal standards of justice." 147 This concern will almost certainly mean that the Human Rights Committee will need to be monitoring the proceedings especially closely, as part of its overseeing of the implementation of the ICCPR in Bangladesh. Then, the Committee against Racial Discrimination may well become engaged if the process is seen to be a possible targeting of the Bihari racial/ethnic group.

As a matter of Bangladeshi law, the Constitution would be supreme. But, in international law, a State cannot raise its domestic law as an excuse for non-compliance with its international obligations. ${ }^{148}$ My purpose in highlighting such irregularities here is to underscore that they will have to be addressed sooner rather than later, before the process starts, otherwise they may affect the overall fairness of the process.

${ }^{147}$ Human Rights Committee, General Comment No. 13: Equality before the courts and the right to a fair and public hearing by an independent court established by law (Art. 14), 4, U.N. Doc. HRI/GEN/1/Rev.1 at 14 (Apr. 13, 1998).

${ }^{148}$ VCLT, supra note 132, art 27 ("A party may not invoke the provisions of its internal law as justification for its failure to perform a treaty"). Although Bangladesh is not a party to the VCLT, there seems to be considerable authority to suggest that this rule has been regarded as a general principle of international law: See e.g. The Alabama Claims (U.S. v. G.B.), 1 Int'l Arb. 495, 656 (“...the government of Her Britannic Majestic cannot justify itself for a failure in due diligence on the plea of insufficiency of the legal means of action which it possessed"); Exchange of Greek and Turkish Population, Advisory Opinion, 1925 P.C.I.J. (Ser. B) No. 10, at 20 ("[Article 18 of the Treaty of Lausanne 1923] merely lays stress on a principle which is self-evident, according to which a State which has contracted valid international obligations is bound to make in its legislation such modifications as may be necessary to ensure the fulfilment of the obligations undertaken"); Applicability of the Obligation to Arbitrate under Section 21 of the United Nations Headquarters Agreement, Advisory Opinion, 1988 I.C.J. Reports 12, 34-35 (Apr. 26, 1988):

It would be sufficient to recall the fundamental principle of international law that international law prevails over domestic law. This principle was endorsed by judicial decision as long ago as the arbitral award of 14 September 1872 in the Alabama case between Great Britain and the United States, and has frequently been recalled since, for example in the case concerning the GrecoBulgarian "Communities" in which the Permanent Court of International Justice laid it down that "it is a generally accepted principle of international law that in the relations between Powers who are contracting Parties to a treaty, the provisions of municipal law cannot prevail over those of the treaty" (P.C.I.J., Series B, No. 17, p. 32). 


\subsection{Personal Jurisdiction}

The International Crimes (Tribunals) Act 1973 was adopted 1 year after the 1972 Collaborators Act. It was designed to deal with the more 'high value' suspects, such as the Pakistanis Prisoners-of-War being held by the Indians and those who were accused of more substantial crimes and could not benefit from the 1973 amnesty. All have long since been released from custody. The act has a very wide personal jurisdiction that could draw in significant numbers of accused. On the basis of the materials that I studied, it seems that crimes in the Bangladeshi war of independence were committed by:

1. Members of the Pakistani Armed Forces

2. Pakistani political leaders

3. Pakistani militias - whether from West Pakistan or East Pakistan

4. Bengali freedom fighters and other Bengali militias

5. Bengali civilians - both pro or anti Pakistan

6. Non-Bengali civilians.

Under Section 3(1) as recently amended, a Tribunal shall have the power to try and punish any individual or group of persons, or any member of any armed, defence forces or auxiliary forces (i.e. forces placed under the control of the Armed Forces for operational, administrative, static and other purposes) who "commits or has committed", in the territory of Bangladesh, whether before or after the commencement of this Act, any of the crimes listed. The amendment here was to insert the "group of persons", but it does not seem like criminalisation of the group as such is what is intended. Joint criminality seems already possible under the law through conspiracy - see later discussion - so this addition does not seem to change much.

On 30 July 2009, at the Second International Conference on Genocide, Truth and Justice in Dhaka, the Hon. Minister for Law, Justice and Parliamentary Affairs categorically stated that there would be no Pakistanis tried under this law. It would only be applied to Bangladeshi nationals. ${ }^{149}$ Pakistan is known to be very concerned about the entire process of revisiting 1971, and the possibility of its nationals being put on trial in Dhaka. The majority of members of the Organisation of Islamic States are also said to be unhappy and

${ }^{149}$ Hon. Minister for Law, Justice and Parliamentary Affairs Shafique Ahmed, Address at the Second International Conference on Genocide, Truth and Justice (Jul. 30, 2009) (Notes on file with author). 
support Pakistan in this matter. With all due respect, the text of the law says that it applies "irrespective" of nationality, and the Minister's understandable concern with placating Pakistan obviously cannot override it. But taking jurisdiction over Pakistanis is a very tricky issue that goes to the heart of this accountability exercise. To focus simply on those whom one can get one's hands on, who were in the scale of things in 1971 merely foot soldiers and followers (the term 'small fish' is often used to describe this type of low-ranking perpetrator), while the planners, commanders and those with control over them remain out of reach creates a dangerously warped process from the start. This problem of inability to touch the ones with greatest responsibility was one of the factors which doomed the East Timor process of accountability at the Special Panels for Serious Crimes. ${ }^{150}$ But, what is Bangladesh to do about the Pakistanis? Strategically, proceeding against locals will bring to light much evidence about the role of the Pakistani Army and political leaders, and it will probably create a wider momentum for some kind of action or remedy from Pakistan. Pakistan, given the condition that it is in, is hardly in a position to start to deal with the crimes of 1971, even if criminal sanction was what its own Justice Hamoodur Rahman recommended. In any event, the sorry precedent of Indonesia's East Timor trials, put on as a result of international pressure and threats of an $\mathrm{ad}$ hoc international tribunal, show how a skilfully a State can twist a judicial process to whitewash its role and that of its soldiers and officials, create a false 'truth' about what happened, and affirm alleged criminals as national heroes in the public eye. ${ }^{151}$ Be that as it may, some kind of accommodation must be reached with Pakistan to ensure that the critical documents and first hand interviews relied on by the Justice Hamoodur Rahman inquiry should be made available to the Bangladeshis.

There are also countries, such as the United Kingdom, where persons said to have been instrumental in atrocities in 1971 are now

${ }^{150}$ For analyses of this, see e.g.: Suzannah Linton, East Timor and Accountability for Serious Crimes, in 3 international criminal law (3rd ed., M. Cherif Bassiouni ed., 2008), 257-283; Suzannah Linton, Indonesia and Accountability for Serious Crimes in East Timor, in 3 InTERNATIONAL CRIMINAL LAw, above, at 399-406; SUZANNAH LINTON, PUTTING THINGS INTO PERSPECTIVE: THE REALITIES OF ACCOUNTABILITY IN EAST TIMOR, INDONESIA AND CAMBODIA (Maryland Series in Contemporary Asian Studies, Vol 3, 2005).

${ }^{151}$ See e.g. Linton, supra note 88. Also, Suzannah Linton, Unravelling the First Three Trials at Indonesia's Ad Hoc Court for Human Rights Violations in East Timor, 17 LEIDEN J. INT'L L. 303 (2004). 
residing. A British Channel 4 television documentary in 1995 examined the allegations against three persons residing in the United Kingdom and found credible evidence of criminal conduct. ${ }^{152}$ It is usually suggested that the United Kingdom could itself be prosecuting such persons on the basis of its Geneva Conventions Act of 1957 which provides for the prosecution of Grave Breaches (but not violations of Common Article 3). Obviously the acts would have to be committed in the international armed conflict stage of the liberation war for this to be applicable. Other options available to States with such persons within their jurisdiction include extradition to Bangladesh pursuant to a request or arrest warrant (dependant on extradition agreements), and stripping a person of residence rights or nationality on the basis of fraudulent statement on application (as done in Canada) and repatriating the person back to the country of origin, Bangladesh.

One other possibility is trials in absentia. Bangladesh's Prevention of Oppression of Women and Children Act 2000 permits this, under Section 20. ${ }^{153}$ The International Crimes (Tribunals) Act As Amended says nothing about trial in the presence of the accused. In fact, Bangladesh has made a reservation to the ICCPR on this matter of in absentia trial. ${ }^{154}$ Such trials are highly frowned upon in common law jurisdictions, but in international human rights law, they are not unlawful if there are sufficient safeguards. The Human Rights Committee has held that in absentia trials are possible where if the State has given effective notice of the hearing and the accused chooses not to appear. ${ }^{155}$ There is already precedent for a full-blown trial in

152 See Ansar Ahmed Ullah, Building an international network: Campaign to seek justice \& the efforts in the UK, a paper presented at the Second International Conference on Genocide, Truth and Justice, Jul. 30-31, 2009, at 5.

153 Children's Act, Act No VIII of 2000 (Bangl.).

${ }^{154}$ See Bangladesh's Reservation to the ICCPR, http://treaties.un.org/Pages/ ViewDetails.aspx $? \mathrm{src}=$ TREATY\&mtdsg_no $=\mathrm{IV}-4 \&$ chapter $=4 \&$ lang $=$ en (last visited Aug. 30, 2009). The full text is extracted below:

The Government of the People's Republic of Bangladesh reserve apply paragraph 3(d) of Article 14 in view of the fact, that, while the existing laws of Bangladesh provide that, in the ordinary course a person, shall be entitled to be tried in his presence, it also provides for a trial to be held in his absence if he is a fugitive offender, or is a person, who being required to appear before a court, fails to present himself or to explain the reasons for non-appearance to the satisfaction of the court.

${ }^{155}$ See e.g. Daniel Monguya Mbenge v. Democratic Republic of Congo (No. 16/ 1977), 14.1, U.N. Doc. CCPR/C/18/D/16/1977 (Mar. 25, 1983). 
absentia (as opposed to a quasi-trial as with Rule 61 proceedings under the ICTY Statute ${ }^{156}$ ), for the Special Tribunal for Lebanon can hold such proceedings. ${ }^{157}$ But there are safeguards: this is only possible when an accused fails to appear as summoned, or does not even appoint a defence lawyer to appear in his stead. In situations where the indictment cannot be served or notified to the accused, it must be properly publicised. Trial in absentia is never going to be a wise option in a situation where there are doubts about the integrity of the criminal justice system.

\subsection{Subject Matter Jurisdiction: Section 3(2)}

\subsubsection{Crimes Against Humanity: Section 3(2)(a)}

The law provides for jurisdiction over crimes against humanity, defined as the following:

namely, murder, extermination, enslavement, deportation, imprisonment, abduction, confinement, torture, rape or other inhumane acts committed against any civilian population or persecutions on political, racial, ethnic or religious grounds, whether or not in violation of the domestic law of the country where perpetrated.

This is an adaptation of the Charter of the IMT Nuremberg (added are the specific acts of imprisonment, abduction, confinement, torture and rape, and ethnicity is added to the persecution provision, some of which come from Control Council Law No. 10; removed are the words "before or during the war"). ${ }^{158}$ As Professor Jescheck has acknowledged, the IMT made new law (in other words, it was ex post facto law in violation of the fundamental principle of nullum crimen, nulla poene sine lege), although he asserts that most of it was in line with domestic law. ${ }^{159}$ The prohibition of crimes against humanity as set out in the Charter was unanimously approved by General Assembly Resolution 95(I), which later led to the International Law

${ }^{156}$ Statute of the International Criminal Tribunal for the Former Yugoslavia, S.C. Res. 827; U.N. SCOR., 48th Sess., 3217th mtg.; U.N. Doc. S/Res/827 (May 25, 1993); 32 I.L.M. 1203 [hereinafter ICTY Statute].

${ }^{157}$ See Paola Gaeta, To be (Present) Or Not to be (Present): Trials in Absentia before the Special Tribunal for Lebanon, 5 J. INT'L CRIM. JUSTICE 1165 (2007).

${ }^{158}$ See Charter of the IMT Nuremburg, supra note 93, art 6(c); Control Council Law No. 10, supra note 82, art II(c).

159 Jescheck, supra note 101, at 50 (this underlines the importance of retaining the domestic law in any domestic prosecution of international crimes). 
Commission's 'Principles of International Law recognized by the Charter of the Nuremburg Tribunal and in the Judgement of the Tribunal'. ${ }^{160}$

The crime against humanity has no conventional roots. The customary prohibition is what forms the basis - not always the exact content - of jurisdiction that has been discussed since World War I. ${ }^{161}$ After the Nuremberg and Tokyo trials, the concept evolved further through Control Council Law No. 10 and cases thereunder, and atrocity cases tried in domestic courts such as Eichmann, ${ }^{162}$ Barbie, ${ }^{163}$ Touvier ${ }^{164}$ and Finta. ${ }^{165}$ The status of the prohibition is evidenced in the 1993 Report of the Secretary-General accompanying the submission of the ICTY Statute to the Security Council, which explained that crimes against humanity are "beyond any doubt part of customary international law". ${ }^{166}$ While there is no doubt that crimes against humanity are prohibited as international crimes, there are differences between all the major definitions, none of which is identical to the elements of the crime that was tried at Nuremburg. This was considered by the Group of Experts on Cambodia, who stated nevertheless that:

${ }^{160}$ G.A. Res 95(I), supra note 93; ILC Nuremburg Principles, supra note 97, Principle VI(c) (under which a crime against humanity is punishable as a crime under international law. The resolution maintained the definitions used by the IMT Nuremburg).

${ }^{161}$ See the 1915 Franco-British-Russian Joint Declaration condemning the massacre of Armenians and calling for all members of the Turkish government to be held responsible for such "crimes against civilization and humanity". This is quoted in the Armenian Memorandum presented by the Greek delegation to the Commission of Fifteen on Mar. 14, 1919. See M. CHERIF BASSIOUNI, CRIMES AGAINST HUMANITY In international LaW 62, n. 84 (2nd ed., 1999); Egon Schwelb, Crimes Against Humanity, 23 BRIT. Y.B. INT'L L. 178, 181, n. 2 (1946); Rouben Paul Adalian, American Diplomatic Correspondence in the Age of Mass Murder: The Armenian Genocide in the US Archives, in AMERICAN AND THE ARMENIAN GENOCIDE OF 1915150 (Jay Winter ed., 2003).

162 Eichmann District Court Judgement, supra note 81.

${ }^{163}$ Fédération nationale des déportés et internés résistants et patriotes and others

v. Barbie 78 I.L.R. 125 (Fr. Cass. crim. 1985).

164 Touvier 100 ILR 338 (Fr. Paris Cours d'assises 1992), rev'd 100 ILR 351 (Fr.

Cass. crim. 1992).

165 R v. Finta, supra note 141.

${ }^{166}$ Report of the UNSG under UNSC Res 808, supra note 100, 948. 
The trends that have now solidified were well in place by 1975 , so that a prosecution of Khmer Rouge leaders for such violations would not violate a fair and reasonable reading of the nullum crimen principle. ${ }^{167}$

The Bangladeshi text, on the face of it, appears to turn ordinary but serious crimes - murder, even mass murder in the form of extermination - into extraordinary crimes simply because they are committed against any civilian population. Missing from the text is the concept of the "widespread or systematic attack" against the civilian population, which is the hallmark of the crime against humanity, and which distinguishes it from ordinary crimes. It is true that the term "widespread or systematic attack" only appeared for the first time in positive law in the Statute of the International Criminal Tribunal for Rwanda [hereinafter ICTR] in 1994. ${ }^{168}$ It was not in the Charter of the IMT Nuremberg, nor was it in the Charter of the IMT Far East. ${ }^{169}$ The requirement that the particular actions be part of a "widespread or systematic attack" against the civilian population came to form an integral part of the crime through the caselaw. ${ }^{170}$ In 1993, the Report of the Secretary-General accompanying the submission of the ICTY Statute to the Security Council explained that crimes against humanity are "inhumane acts of a very serious nature...committed as part of a widespread or systematic attack against any civilian population". 171 In spite of this, it was not felt necessary to include it in the definition in the Statute. But the Tadic decision confirmed the principle that crimes against humanity must be committed as part of a widespread or systematic attack against the civilian population, and it requires this as part of the burden of

${ }^{167}$ Report of the Group of Experts for Cambodia established pursuant to General Assembly Resolution 52/135, - 71, U.N. Doc. A/53/850-S/1999/231, Annex (Feb. 18, 1999) [hereinafter Cambodia Experts Report].

${ }^{168}$ Statute of the International Tribunal for Rwanda, S.C. Res. 955; U.N. SCOR 49th Sess., 3217th mtg., U.N. Doc. S/Res/955 (Nov. 8, 1994); 33 I.L.M. 1598.

${ }^{169}$ Charter of the International Military Tribunal for the Far East (As amended 26 April 1946) 14 State Dept Bull, 8990; TIAS No. 1589 [hereinafter Charter of the IMT Far East].

170 The United Nations War Crimes Commission had confirmed the prototype of the 'widespread or systematic plan' by observing that 'systematic mass action' is required for a finding of crime against humanity in the context of Second World War cases: See BASSIOUNI, supra note 161, at 37.

${ }^{171}$ Report of the UNSG under UNSC Res 808, supra note 100, 48. 
proving the elements of the crime. ${ }^{172}$ In Almonacid-Arellano et al. v. Chile, the Inter-American Court of Human Rights considered crimes against humanity in Chile in 1973. It found, inter alia, that they had been committed, the underlying crimes having been "committed as part of a systematic and general pattern against the civil population". ${ }^{173}$ The element of a "widespread or systematic attack against the civilian population" is also included in the crimes against humanity provision used at Cambodia's ECCC for 1975-1979. ${ }^{174}$ The court trying the Bangladeshi crimes will have to establish the state of customary law in 1971 and rule on this matter of whether the crime against humanity then had to be committed as part of a "widespread or systematic attack" on the civilian population.

There also has to be a 'nexus' or a 'link' between the accused's acts (the underlying core crime) and the "widespread or systematic" attack on the civilian population. In modern international criminal law, it is clear that the acts of the accused must comprise part of a pattern of widespread or systematic crimes directed against a civilian population and the accused must have known that his acts fit into such a pattern. ${ }^{175}$ The underlying core crime need not be an attack ${ }^{176}$ or in itself a widespread or systematic attack, but it needs to be part of it. 'Attack' here does not mean an armed attack as under the international law of armed conflict. But, that obviously does not mean that military or other acts of violence in armed conflict cannot amount to an 'attack' for the purposes of crimes against humanity. For this crime, the notion of attack is wider than that of the international law of armed conflict, and "encompasses any mistreatment of the civilian population". ${ }^{177}$ When establishing an 'attack' of this nature, it is irrelevant that the other side committed atrocities, although such

172 Tadić Appeal Judgement, supra note 138, $\uparrow$ 248. See also ICTR Statute, supra note 168 , art 3 .

${ }^{173}$ Almonacid-Arellano et al. v. Chile, Inter-Am. C.H.R., Report No. 44/02, I.A.C.H.R. Doc. 5 rev 1 at 208, 104 (2002).

${ }^{174}$ Law on the Establishment of the Extraordinary Chambers, with inclusion of amendments as promulgated on 27 October 2004, NS/RKM/1004/006, art 5 (Cambodia) (Unofficial translation by the Council of Jurists) [hereinafter Law on ECCC]; ICTR Statute, supra note 168.

175 Tadić Appeal Judgement, supra note 138, ฯ 248, 252, 271.

${ }^{176}$ Prosecutor v. Kunarac et al., Case No. IT-96-23-A \& 23/1-A, Appeal Judgement, 917 (Jun. 12, 2002) [hereinafter Kunarac Appeal Judgement].

${ }^{177}$ Prosecutor v. Vasiljević, Case No. IT-98-32-T, Judgement, $\uparrow$ 29-30 (Nov. 29, 2002) [hereinafter Vasiljević Trial Judgement]. 
considerations would go towards mitigation of any sentence following a conviction.

What of policy - does the prosecution have to show that there was a policy to commit widespread or systematic attacks on the civilian population in 1971? There was some initially contradictory jurisprudence, but according to the law of the contemporary tribunals, there is no need in customary law for a plan or policy as such but its existence can go towards proving the 'systematic' element. "The existence of policy or plan may be evidentially relevant, but it is not a legal element of the crime". ${ }^{178}$ Whether this was the case in 1971 will have to be considered by the Bangladeshi Tribunal. It should be noted that the ICC Statute ${ }^{179}$ goes beyond custom in specifically requiring proof of policy; ${ }^{180}$ this is because it is intended to catch particularly egregious actions. But, it is helpful in that it provides some guidance on what to look for: relevant policies can be active, or be implemented by a deliberate failure to take action, which is consciously aimed at encouraging such attack. The existence of such a policy cannot be inferred solely from the absence of governmental or organisational action. In other words, one needs more than mere inaction. The writings and studies on the 1971 war strongly suggest that there was indeed a policy, as well as systematic planning of the Pakistani operations in the East.

On the basis of a textual analysis of Section 3(2)(a), there are two interpretations possible on the discriminatory intent ("on political, racial, ethnic or religious grounds"): (1) All the crimes listed have to be perpetrated with discriminatory intent; (2) Only persecution has to be committed with discriminatory intent. Modern international criminal law makes it clear that in custom, it is just persecution which requires discrimination. ${ }^{181}$ It is interesting to compare the Bangladeshi provision, for crimes of the 1971 war, with that of the

${ }^{178}$ Kunarac Appeal Judgement, supra note 176, 98.

179 ICC Statute, supra note 98.

${ }^{180}$ Kunarac Appeal Judgement, supra note 176, $\uparrow$ 98. This requirement was applied in the ICC recently, as a matter of law: Prosecutor v. Omar Al Bashir, Case No. ICC-02/05-01/09-3, Decision on the Prosecution's Application for a Warrant of Arrest against Omar Hassan Ahmad Al Bashir, 79 est. seq. (Mar. 4, 2009).

${ }^{181}$ The crime against humanity has 'never required that every such crime must be committed with discrimination' (see Tadić Appeal Judgement, supra note 138, ๆ 288-292). The ICTY went through tribunal statutes, international and domestic crimes against humanity cases. This was confirmed by the ICTR Appeals Chamber in Prosecutor v. Akayesu, Case No. ICTR-96-1-A, Appeal Judgement, 464 (Jun. 1, 2001) [hereinafter Akayesu Appeal Judgement]. 
Cambodian Court's definition of crimes against humanity, for crimes committed between 1975 and 1979:

Crimes against humanity, which have no statute of limitations, are any acts committed as part of a widespread or systematic attack directed against any civilian population, on national, political, ethnical, racial or religious grounds, such as: murder; extermination; enslavement; deportation; imprisonment; torture; rape; persecutions on political, racial, and religious grounds; other inhumane acts. ${ }^{182}$

The ECCC provision is identical to that of the Statute of the ICTR. It requires that all crimes against humanity, not just persecution, have to be committed with a discriminatory intent. The issue of the discriminatory element in this provision was found, in the ICTR's Akayesu Appeal Judgement, to be a matter of jurisdiction. ${ }^{183}$ The Appeals Chamber distinguished the requirement of discrimination in the chapeau and the requirement of discrimination in the core crimes. It determined that the chapeau reflects the drafters' intent to restrict jurisdiction of the court to a certain type of crimes against humanity that is "committed as part of a widespread or systematic attack against any civilian population" on certain discriminatory grounds. ${ }^{184}$ So, the category of "widespread or systematic attack" that the ICTR can look at is that committed with discriminatory intent - this must therefore be proven as part of the chapeau. All this does is narrow the scope of the court's jurisdiction but does not introduce additional element in the legal ingredients of the crime as these are known in customary international law. The intention of the drafter (Security Council) was not to depart from customary law. "It limited at the very most the jurisdiction of the Tribunal to a sub-group of such crimes, which in actuality may be committed in a particular situation." 185 So, for Bangladesh, this decision indicates the following. In customary international law, it is only for persecution that the core crime must be committed with a discriminatory intent. For all other core crimes, there is no need to show discrimination. The "widespread or systematic attack" on the civilian population, in the absence of a statutory provision, does not have to be committed with a discriminatory intent. This should move the Bangladeshi tribunal towards finding discriminatory intent is required only for persecution.

\footnotetext{
${ }^{182}$ Law on ECCC, supra note 174, art 5.

183 Akayesu Appeal Judgement, supra note 181, ๆ 460-469, 495.

${ }^{184}$ Id., 464.

${ }^{185} I d .,-465$.
} 
The text of the Bangladeshi law does not require a nexus with armed conflict. ${ }^{186}$ Is this a correct reflection of customary law in 1971? There was initially, in Article 6(c) of the Charter of the IMT Nuremberg, a nexus with international armed conflict and other crimes in the Charter, namely War Crimes and Crimes against Peace. The international armed conflict linkage to war crimes was strategic and necessary, for the war crimes provision was the most secure of the Charter's provisions in terms of respecting the principle of nulla poena sine lege. Very shortly after, Article II of Control Council Law No. 10 removed that requirement of a nexus. It was not in the Israeli Nazi and Nazi Collaborators Act. The International Law Commission's drafts of the elements of the crime against humanity beginning with its 1954 Draft Code of Offences Against the Peace and Security of Mankind did not require a nexus to any armed conflict. By 1968, the nexus was not cited in the Convention on the Non-Applicability of the Statutory Limitation to War Crimes and Crimes Against Humanity. ${ }^{187}$ Professor Cassese, in commenting on the European Court of Human Rights case of Kolk \& Kislyiy v. Estonia, has said that the crystallisation of the no-nexus rule probably began at this time. ${ }^{188}$ Yet, the 1993 ICTY Statute reintroduced the nexus. In 1995, the ICTY Tadic Appeals Chamber held that: "[i]t is by now a settled rule of customary international law that crimes against humanity do not require a connection to international armed conflict". ${ }^{189}$ But, this 1995 decision was nuanced on armed conflict as such: "Indeed...customary international law may not require a connection between crimes against humanity and any conflict at all." ${ }^{190}$ The 1994 ICTR Statute did not include any nexus and neither is it to be found in the 1998 ICC Statute and the 2002 SCSL Statute. So, it would seem to be correct that there was no need for a nexus to an international armed conflict in 1971, but it is not as certain on armed conflict per se.

186 The recognised definition of armed conflict is that laid down in Prosecutor v. Tadić, Case No. IT-94-1-AR72, Decision on the Defence Motion for Interlocutory Appeal on Jurisdiction (Oct. 2, 1995) [hereinafter Tadić Decision on Jurisdiction]. This will be discussed later in the section analysing crimes in armed conflict.

${ }^{187}$ At relevant time, Pakistan was not a party and to-date, Bangladesh remains a non-party.

${ }^{188}$ Antonio Cassese, Balancing the Prosecution of Crimes against Humanity and Non-Retroactivity of Criminal Law: The Kolk and Kislyiy v. Estonia Case before the ECHR, 4 J. INT'L J. CRIM. JUSTICE 410 (2006).

189 Tadić Decision on Jurisdiction, supra note 186, 141.

${ }^{190} I d$. 
Having said all of that, this 'problem' is very easily deflected by the realities of the situation: there was undeniably an armed conflict of some kind in East Pakistan, now known as Bangladesh, from 25 March 1971 until the surrender on 15 December 1971.

The Bangladeshi court will have to rule on these, and other matters relating to the state of the customary prohibition of crimes against humanity in 1971, including the elements of the core crimes, in particular extermination and persecution, and the additional core crimes of imprisonment, abduction, confinement, torture and rape. Given the prevalence of allegations of sexual violence, the definition of rape at that point in time will have to be identified. The definition in the then applicable Penal Code of 1860 reads:

375. A man is said to commit "rape" who except in the case hereinafter excepted, has sexual intercourse with a woman under circumstances falling under any of the five following descriptions: Firstly. Against her will. Secondly. Without her consent. Thirdly. With her consent, when her consent has been obtained by putting her in fear of death, or of hurt. Fourthly. With her consent, when the man knows that he is not her husband, and that her consent is given because she believes that he is another man to whom she is or believes herself to be lawfully married. Fifthly. With or without her consent, when she is under fourteen years of age.

The statutory explanation given is that "[p]enetration is sufficient to constitute the sexual intercourse necessary to the offence of rape. Exception. Sexual intercourse by a man with his own wife, the wife not being under 13 years of age, is not rape." This can of course be contrasted with the contemporary international definition used at the ICC, which draws from ICTY jurisprudence. ${ }^{191}$

${ }^{191}$ See ICC Statute, supra note 98, art 7; Elements of Crimes, ICC-ASP/1/3 (part II-B), art 7(1)(g)-1, adopted Sept. 9, 2002; entered into force Sept. 9, 2002 [hereinafter Elements of Crimes]:

1. The perpetrator invaded the body of a person by conduct resulting in penetration, however slight, of any part of the body of the victim or of the perpetrator with a sexual organ, or of the anal or genital opening of the victim with any object or any other part of the body.

2. The invasion was committed by force, or by threat of force or coercion, such as that caused by fear of violence, duress, detention, psychological oppression or abuse of power, against such person or another person, or by taking advantage of a coercive environment, or the invasion was committed against a person incapable of giving genuine consent. (Footnotes omitted)

See also the definitions developed in the ad hoc Tribunals jurisprudence including: Akayesu Appeal Judgement, supra note 181; Kunarac Appeal Judgement, supra note 176 and Prosecutor v. Furundžija, Case No. IT-95-17/1-T, Judgement, ฯ 185 
Excluded from the definition of both Bangladeshi laws are sexual slavery, enforced prostitution, forced pregnancy, enforced sterilisation, or any other form of sexual violence of comparable gravity. ${ }^{192}$ Sexual violence has traditionally been neglected as an international crime. In Bangladesh today, it continues to be regarded as a crime against personal 'dignity' or 'honour' of women, rather than criminal acts aimed at the physical or mental integrity of the person. ${ }^{193}$ In the post World War II cases, sexual offences were generally caught under "other inhumane treatment" - rapes in Nanjing were prosecuted at the International Military Tribunal for the Far East as "other inhumane acts". Control Council Law No. 10 was the first express inclusion of rape as a crime against humanity (no rape prosecutions were conducted under it); it was also expressly included as a core crime in the crime against humanity provisions of the ICTY and ICTR Statutes. These too did not refer to other forms of sexual or gender violence, and the Bangladeshi process will invariably also have to fill the lacunae with reliance on "other inhumane acts".

\subsubsection{Crimes Against Peace: Section 3(2)(b)}

Aggression is one of the most serious violations of international law, engaging the responsibility of the aggressor state in international law. It is a violation for which the state may be held responsible. More problematic is whether those of its officials who had the necessary authority or power to plan, prepare, initiate or wage aggression may be held individually criminally responsible. According to the IMT's Nuremberg judgement, to "initiate a war of aggression... is not only an international crime; it is the supreme international crime differing

\section{Footnote 191 continued}

(Dec. 10, 1998) ("...[T]he following may be accepted as the objective elements of rape: (i) the sexual penetration, however slight: (a) of the vagina or anus of the victim by the penis of the perpetrator or any other object used by the perpetrator; or (b) of the mouth of the victim by the penis of the perpetrator; (ii) by coercion or force or threat of force against the victim or a third person").

192 See ICC Statute, supra note 98, art 7; Elements of Crimes, supra note 191.

${ }^{193}$ See Rubaiyat Hossain, Trauma of the Women, Trauma of the Nation: A Feminist Discourse on Izzat, a paper presented at the Second International Conference on Genocide, Truth and Justice, Jul. 30-31, 2009. She points out that izzat means prestige, dignity, honour, or chastity. Sexual violence violates a woman's izzat, causing spoiling or loss of prestige, dignity, honour, or chastity. In Bangladesh, the sexual violence of 1971 is referred to in the sense of izzat. 
only from other war crimes in that it contains within itself the accumulated evil of the whole". ${ }^{194}$

The Bangladeshi law uses the classic IMT Nuremberg provision: "Crimes against Peace: namely, planning, preparation, initiation or waging of a war of aggression or a war in violation of international treaties, agreements or assurances", but omitted are the words "or participation in a Common Plan or Conspiracy for the accomplishment of any of the foregoing". This omission may perhaps reflect the continental lawyer's traditional distaste for this notion of criminality that is prevalent in the common law system, and the notion of 'common plan' which was very controversial at Nuremberg.

It is unlikely that this provision will ever be used, as even if there are major legal obstades (see laber) the chances of ever being able to exercise jurisdiction over persons who were responsible for the use of force in East Pakistan are slim. But the symbolism is important and its psychological value is not to be underestimated in such a situation. It is a satisfaction that has been denied the East Timorese, who also view their State as having come into being with an internationallyunrecognised Unilateral Declaration of Independence; they were invaded and occupied by Indonesia for 24 years. The Cambodians too have been denied the satisfaction of such a provision in their law, for it raises the spectre of the saturation bombing of Cambodia by the United States in pursuit of the Vietcong. For both of East Timor and Cambodia, an aggression provision in domestic law also leads to troublesome yet legitimate questions about the States that assisted other States in breaking the rules. In the circumstances of Bangladesh, it is understandable that the drafters chose to rely on something for which there was already precedent.

But, there are legal problems. Aggression is of course, about inter State relations, not intra-State affairs; thus there are inherent problems with the concept being applied to the East Pakistan war of liberation, involving as it did, secession from the State of Pakistan. The inclusion of this never-prosecuted-before provision in the Charters of the Nuremberg and Tokyo Tribunals was highly contentious and is always cited as one of the numerous grounds for critiquing the fairness of those proceedings. As Professor Jescheck wrote in 2004, this provision went beyond the pre-existing law, relied on the methodology of analogy which was unconvincing and

${ }^{194}$ International Military Tribunal (Nuremburg), Judgement and Sentences, reprinted in 41 AM. J. INT'L L. 172, 186 (1974) [hereinafter IMT Judgement]. 
erroneously tried to ground the criminal punishment of the crime against peace in customary law. ${ }^{195} \mathrm{He}$ also raised the lack of specificity, stating that "A sanction as grave as individual criminal responsibility for the war of aggression would have had to be spelled out explicitly in the [Kellogg-Briandt] Pact in order to take effect in international law". ${ }^{196}$ Professor Cassese also dismisses the justification used by the IMT Nuremberg in its judgement, and considers that the 'crime against peace' (and the 'crime against humanity') were new crimes invented by the London Agreement of 1945. In acting on this new 'crime against peace', the IMT “applied international law retroactively, as the defence counsel at Nuremberg right stressed". ${ }^{197}$ He, like many others, challenges the judgement's claim that the Charter was, in the matter of the crime against peace and the crime against humanity "the expression of international law existing at the time of its creation; and to that extent [it was] itself a contribution to international law". ${ }^{198}$ There was no such thing as the crime against peace in international law until it appeared in the London Agreement and was applied at Nuremberg. It is true that this definition was then used for the Tokyo Tribunal and accepted by the UN General Assembly in its Resolution 95(I) of 1946. A differently defined concept of 'aggression' was included in the International Law Commission's Draft Code of Crimes against Peace and the Security of Mankind. ${ }^{199}$ However, outside of the Nuremberg and Tokyo tribunals, and certain of the trials under Control Council Law No. 10, prosecutions for crimes against peace have been particularly rare. Telford Taylor reported that a total of 25 Japanese and 16 Germans were convicted of this charge. ${ }^{200}$ The Finnish leadership trial at Helsinki and that of Hermann Roechlin in Rastatt also involved charges of crimes

\footnotetext{
195 Jescheck, supra note 101, at 39, 41-42.

196 Id., at 48-49.

197 ANTONIO CASSESE, INTERNATIONAL CRIMINAL LAW 43 (2nd ed., 2008).

198 ANTONIO CASSESE, INTERNATIONAL CRIMINAL LAW 148 (1st ed., 2003). See also CASSESE, supra note 197, at 43-44. See also e.g., Georg Schwarzenberger, The Judgement of Nuremberg, 21 TUL. L. REV. 329 (1947) and Sheldon Glueck, The Nuremberg Trial and Aggressive War, 59 HARV. L. REV. 396 (1946).

${ }^{199}$ ILC Nuremburg Principles, supra note 97.

200 TELFORD TAYLOR, NUREMBERG TRIALS, WAR CRIMES AND INTERNATIONAL LAW, (1949), at 86.
} 
against peace. ${ }^{201}$ There was also domestic prosecution of the Crime against Peace when China tried certain captured Japanese military officers (eg. Takashi Sakai) in relation to Japan's "war of aggression" against China during World War II. ${ }^{202}$ There do not appear to have been any prosecutions outside of the World War II context. In Article 19(3) of its Draft Articles on State Responsibility, the International Law Commission controversially attempted to develop a provision that provided for serious breaches of international peace and security to constitute international crimes for which the State may be held criminally liable, but this was abandoned due to strong objections by States. It is no accident that the crime of aggression or the crime against peace is not part of the subject matter of either of the ICTY or ICTR (the absence is particularly striking given the circumstances covered by the ICTY). In 2009, the concept and elements of the crime of aggression are still being argued over by the States Parties to the ICC Statute, indicating that even today we do not have the necessary consensus on what this actually means. ${ }^{203}$

In terms of international law, it seems that the State of Bangladesh did not come into being until after the war. Regardless of the exceptional recognition that was eventually given by all nations in the world to this State born of secession in the face of horrendous abuse by Pakistan, the International Commission of Jurists' careful study was clear - and correct - that the Unilateral Declaration of Independence was not valid in international law in 1971. Until India's engagement as a belligerent, what happened in East Pakistan was an internal matter, and not a matter of States "planning, preparation, initiation or waging of a war of aggression or a war" against other States. We have little to go on beyond the contested Nuremberg and Tokyo judgements for what crimes against peace actually constitute, but all the cases have concerned international armed conflict in the classical sense. Two highly relevant

201 B. V. A. RÖLING \& C.F. RÜTER, THE TOKYO JUDGEMENT: THE INTERNATIONAL MILITARY TRIBUNAL FOR THE FAR EAST (1977), at XIII, fn. 7.

202 See Trial of Takashi Sakai, Law Reports of Trials of War Criminals, Vol. III, The United States War Crimes Commission, 1948, pp.1-7. The legal basis was contained in Rules Governing the Trial of War Criminals, later to become the Law Governing the Trial of War Criminals, 24 October 1946, discussed in the same volume.

${ }^{203}$ For a more comprehensive account of the struggle to have the crime of aggression defined, See OSCAR SOLERA, DEFINING THE CRIME OF AGGRESSION (2007). 
documents that we do have are the United Nations Declaration on Friendly Relations between States ${ }^{204}$ and the Declaration on the Definition of Aggression. ${ }^{205}$ In neither document is it considered aggression or a crime against peace for a sovereign State to attempt to quell attempts at secession from its internationally recognised territorial boundaries. This, of course, does not mean that Pakistan could do what it wanted in the East. But it does underscore that the crime against peace is a State-on-State matter, and under international law of the time, there was no sovereign State of Bangladesh. This analysis is supported by the finding of the International Commission of Jurists that "no question arises of a 'crime against peace' in Bangladesh". 206

\subsubsection{Genocide: Section 3(2)(c)}

The label that is used to describe criminal behaviour arising from atrocity can be a very emotive and sensitive issue. In Bangladeshi proaccountability circles, genocide is the commonly used term to describe the terrible events of 1971. Others, such as the eyewitness journalist Sydney Schamberg, have also used this label. ${ }^{207}$ As has been noted, the International Commission of Jurists did conclude that genocide had been perpetrated in Bangladesh. But they found it was not committed against the Bengali group as such. ${ }^{208}$ Members of the Awami League, students and Hindus were certainly singled out for special attention, ${ }^{209}$ and the International Commission of Jurists did not rule out genocide as being committed against part of the Bengali people. But they were only prepared to find "a strong prima facie case that the crime of genocide was committed against the group comprising the Hindu population of East Bengal". ${ }^{210}$ As to the documented attacks by Bengalis on non-Bengalis, the report recognised the complexities in providing the dolus specialis, and while it

${ }^{204}$ Declaration on Principles of International Law Concerning Friendly Relations and Cooperation Among States in accordance with the Charter of the United Nations, G.A. Res. 2625 (XXV), U.N. Doc. A/8018 (Oct. 24, 1970) (adopted without a vote) [hereinafter Declaration on Friendly Relations between States].

${ }^{205}$ Definition of Aggression, G.A. Res 3314 (XXIX), U.N. GAOR, 29th Sess., Supp. No. 31 (Dec. 14, 1974) (adopted by consensus) [hereinafter Definition of Aggression].

206 ICJ EAST PAKISTAN 1971 REPORT, supra note 5, at 59.

${ }^{207}$ See Sydney Schamberg, The Pakistani Slaughter That Nixon Ignored, NEw york times, May 3, 1994. See also Rounag Jahan, Genocide in Bangladesh, in CENTURY OF GENOCIDE 295-331 (2nd ed., Totten, Parsons \& Charney eds., 2004).

208 ICJ EAST PAKISTAN 1971 REPORT, supra note 5, at 56.

${ }^{209} I d$., at 56.

${ }^{210} I d$., at 57. 
did not rule out the fact that certain individuals may have had such intent, took the position that "[f]or our part, we find it difficult to accept that spontaneous and frenzied mob violence against a particular section of the community from whom the mob senses danger and hostility is to be regarded as possessing the necessary element of conscious intent to constitute the crime of genocide". ${ }^{211}$

The genocide definition in the International Crimes (Tribunals) Act As Amended is that of Article II of the Genocide Convention, with 2 differences. Political groups are added, and the phrase "as such" has become "such as". The ancillary modes of perpetration of genocide in Article III are excluded, which is not in itself fatal since modes of responsibility for crimes are covered elsewhere in the legislation. But, the absence in the 1973 Act of an express provision for the mode of responsibility of incitement, discussed later in the section on modes of responsibility, leaves a lacunae for there may be no way to prosecute "direct and public incitement to commit genocide". 212

The problem with the Bangladeshi addition of political groups is that this was one of the groups deliberately excluded from the ambit of the crime of genocide set out in the Genocide Convention. ${ }^{213}$ States that were engaged in the drafting process did not want 'their own people' to be tried for genocide for the very common practice of targeting their political enemies. And, as is well known, efforts to change the definition of genocide for the ICC by adding 'political groups' were resoundingly defeated at the Rome Conference. Thus, the Statute of the ICC preserved the definition that already existed in treaty and customary law, and which continues to so exist.

It is pertinent to recall here that like Bangladesh, Cambodia also tampered with the conventional definition of genocide. In August 1979, two of the leaders of the Khmer Rouge, Pol Pot and Ieng Sary, were tried in absentia over 5 days from 15 to 19 August 1979 by a People's Revolutionary Tribunal of the Peoples Republic of Kampuchea. The

${ }^{211} I d$., at 57 .

212 But see infra text accompanying note 305.

${ }^{213}$ Prosecutor v. Jelisić, Case No. IT-96-10-T, Judgement, 69 (Dec. 14, 1999); Prosecutor v. Rutaganda, Case No. ICTR-96-3-T, Judgement and Sentence $95-57$ (Dec. 6, 1999); Prosecutor v. Akayesu, Case No. ICTR-96-1-T, Judgement, 516 (Sept. 2, 1998) [hereinafter Akayesu Trial Judgement] (Also held that any "stable and permanent group" should also be protected; William Schabas, Comments on Article 6 of ICC Statute, in COMMENTARY ON THE ROME STATUTE OF THE INTERNATIONAL CRIMINAL COURT: OBSERVERS' NOTES, ARTICLE By ARTICLE 149-150 (2nd ed., Otto Triffterer ed., 2008); WILLIAM SCHABAS, GENOCIDE IN INTERNATIONAL LAW: THE CRIME OF CRIMES 179-189 (2000) [hereinafter SCHABAS, GENOCIDE]. 
action was brought under the charter of the special tribunal, Decree Law No. 1 dated 15 July $1979^{214}$ and on the basis of an indictment dated 30 July 1979. Article 1 gave the tribunal jurisdiction over

the acts of genocide committed by the Pol Pot - Ieng Sary clique, namely, planned massacres of groups of innocent people, expulsion of inhabitants of cities and villages in order to concentrate them, and force them to do hard labour in conditions leading to their physical and mental destruction; wiping out religion, destroying political, cultural and social structures and family and social relations.

This was not genocide as international lawyers know from the Genocide Convention. The entire process was widely denounced for being a sham. ${ }^{215}$ Two decades later, another attempt by the Royal Government to introduce a tailor-made definition of genocide, the better to convict, was rejected by the United Nations during negotiations. ${ }^{216}$ As it is, nobody has yet to be been charged with genocide in Cambodia before the ECCC. If it wishes to proceed with genocide charges, the prosecution in Bangladesh would be well advised to keep within the four protected groups - national, ethnic, racial or religious - and not to venture into bringing charges against anyone for participation in genocide of a political group. To venture beyond would be to violate the principle of legality.

The original language of both International Crimes (Tribunals) Act 1973, and its 2009 amendment, is English. There was probably an un-intentional mix-up with the two little words "as" and "such". But all lawyers know that innocent mix-ups can have major implications in law. In the Genocide Convention, "as such" is a phrase that matters a lot in the context of the definition of the crime. The "as such" emphasises the prohibited targeting of protected groups, which a critical aspect of the concept of genocide. ${ }^{217}$ The ultimate target is the group, and individuals are targeted because they are members of

${ }^{214}$ Decree Law No. 1: Establishment of People's Revolutionary Tribunal at Phnom Penh to Try the Pol Pot-Ieng Sary Clique for the Crime of Genocide, Jul. 15, 1979 (Cambodia).

215 Cambodia Experts Report, supra note 167, 43. See William Schabas, Cambodia: Was it really Genocide?, 23 HUM. RTS. Q. 470 (2001).

216 SCHABAS, GENOCIDE, supra note 213, at 475.

${ }^{217}$ Bosnia v. Serbia 2007 Judgement, supra note 132, 193 ("requires an intent to destroy a collection of people who have a particular group identity"). 
the group. The "as such" underscores that. In Section 3(2)(c) of the International Crimes (Tribunals) Act As Amended, the turn to "such as" not just shifts the emphasis away from the targeting of the protected groups to the core crimes, but it also turns the Genocide Convention's closed list of core crimes into a merely illustrative list.

I have already raised the issue of the application of judgements of foreign courts and tribunals in the courts of Bangladesh. It will of course be essential for the Tribunal to examine the wealth of recent jurisprudence - with care to respect the principle of legality - on issues such as the identification of the national, ethnic, racial or religious groups, elements of the core crimes, command responsibility over genocide and the mental intent for genocide.

\subsubsection{Crimes in Armed Conflicts}

The International Crimes (Tribunals) Act As Amended has two provisions for crimes in armed conflict, and neither expressly provides for prosecution of Grave Breaches of the Geneva Conventions of 1949. It is possible that the architecture was meant to reflect the traditional distinction between (1) the rules governing combat operations, the means and methods of fighting (Hague law) and (2) the humanitarian rules directed purely at protecting non-participants in combat, for example civilians (Geneva law). The Bangladeshi tribunal will have to go through a logical and systematic interpretation of the provisions, as was done by the ICTY Appeals Chamber in the Tadic case, to see how they relate to each other, and to the legislation as a whole. ${ }^{218}$ This is going to be a complex task.

There seem to have been three stages to the armed conflict. In terms of the international law of armed conflict, this armed conflict mutated from a Common Article 3 situation of "armed conflict not of an international character" to an internationalised armed conflict, to a full international armed conflict. In my assessment of "armed conflict", I rely on the Tadic Decision on Jurisdiction, where the ICTY's Appeals Chamber observed that the definition of an armed conflict varies depending on whether the hostilities are international or internal: ${ }^{219}$

[A]n armed conflict exists whenever there is a resort to armed force between States or protracted armed violence between governmental authorities and organized armed groups or between such groups within a State. International humanitarian law applies from the initiation of such armed conflicts and extends beyond the cessation

${ }^{218}$ See Tadić Decision on Jurisdiction, supra note 186.

${ }^{219}$ Id., 67. 
of hostilities until a general conclusion of peace is reached; or, in the case of internal conflicts, a peaceful settlement is achieved. ${ }^{220}$

It is helpful that the International Court of Justice has recently conceded that it may be correct that international criminal law uses a different standard than the Nicaragua test in assessing the degree of linkage that is necessary between a non-State entity and a State in order to internationalise an armed conflict and trigger the application of the Geneva Conventions 1949. ${ }^{221}$ The Tadic decision examined the matter of internationalisation of a non-international armed conflict. In case of an internal armed conflict breaking out on the territory of a State, it may become international (or, depending upon the circumstances, be international in character alongside an internal armed conflict) if (i) another State intervenes in that conflict through its troops, or alternatively (ii) some of the participants in the internal armed conflict act on behalf of that other State. ${ }^{222}$

Tadic established that an armed conflict, which is otherwise internal, is internationalised if a foreign state exercises 'overall control' over the military forces of one of the parties to that conflict. The

${ }^{220} I d$., 70. It is also relevant to consider Pictet's authoritative Commentary on Common Article 3. He suggests useful criteria for what could amount to an "armed conflict not of an international nature":

1. That the Party in revolt against the de jure Government possesses an organized military force, an authority responsible for its acts, acting within a determinate territory and having the means of respecting and ensuring respect for the Convention. 2. That the legal Government is obliged to have recourse to the regular military forces against insurgents organized as military in possession of a part of the national territory. 3. (a) That the de jure Government has recognized the insurgents as belligerents; or (b) that it has claimed for itself the rights of a belligerent; or (c) that it has accorded the insurgents recognition as belligerents for the purposes only of the present Convention; or (d) that the dispute has been admitted to the agenda of the Security Council or the General Assembly of the United Nations as being a threat to international peace, a breach of peace, or an act of aggression. 4. (a) That the insurgents have an organization purporting to have the characteristics of a State. (b) That the insurgent civil authority exercises de facto authority over persons within a determinate portion of the national territory. (c) That the armed forces act under the direction of an organized authority and are prepared to observe the ordinary laws of war. (d) That the insurgent civil authority agrees to be bound by the provisions of the Convention.

4 the geneVA CONVENTIONS OF 12 AUgust 1949: COMMENTARy 35-36 (Jean Pictet ed., 1958).

${ }^{221}$ Bosnia v. Serbia 2007 Judgement, supra note 132, 403.

222 Tadić Appeal Judgement, supra note 138, ๑ 84. 
'overall control' test set forth in the Tadic Appeal Judgement has been internally confirmed as the applicable criteria for determining the existence of an international armed conflict. ${ }^{223}$ Tadic also held that if the controlling State is not the territorial State where the armed clashes occur or where at any rate the armed units perform their acts, more extensive and compelling evidence is required to show that the State is genuinely in control of the units or groups not merely by financing and equipping them, but also by generally directing or helping plan their actions. ${ }^{224}$

As for international armed conflict itself, Common Article 2 of the Geneva Conventions refers to "all cases of declared war or of any other armed conflict which may arise between two or more of the High Contracting Parties, even if the state of war is not recognised by one of them". Pictet has argued that any difference arising between two States and leading to the intervention of members of the armed forces is an international armed conflict sufficient to trigger the applicability of Common Article 2. For him, the occurrence of de facto hostilities is enough. ${ }^{225}$ "It makes no difference how long the conflict lasts or how much slaughter takes place. The respect due to the human person is not measured by the number of victims". Thus, hostile acts involving military operations, the use of a State's armed forces and weaponry, leading to armed engagement with the other State's forces suffice. For Professor Greenwood, "[a]n international armed conflict exists if one party uses force of arms against another party.... It is irrelevant whether the parties to the conflict consider themselves to be at war with each other and how they describe this conflict". ${ }^{226}$ Finally, according to Pictet, the term 'armed conflict' was a deliberate choice so as to prevent arguments by a State that is using arms to commit hostile act against another State that it is not making war but merely engaging in police action or acting in legitimate self-defence. ${ }^{227}$

${ }^{223}$ Delalić et al. Trial Judgement, supra note 136, $\uparrow 378$, aff'd Prosecutor v. Delalić, Case No. IT-96-21-A, Appeal Judgement, ๆ 26 (Feb. 20, 2001) [hereinafter Delalić et al. Appeal Judgement].

${ }^{224}$ Tadić Appeal Judgement, supra note 138, ๆף 137-138.

2254 THE GENEVA CONVENTIONS OF 12 AUGUST 1949: COMMENTARY, supra note 220, at 20 (commenting on common Article 2).

${ }^{226}$ Christopher Greenwood, Scope of Application of Humanitarian Law, in HANDBOOK OF HUMANITARIAN LAW IN ARMED CONFLict 46 (2nd ed., Dieter Fleck ed., 2008).

2274 THE GENEVA CONVENTIONS OF 12 AUGUST 1949: COMMENTARY, supra note 220, at 20 (commenting on common Article 2). 
The International Commission of Jurists viewed the conflict in East Pakistan as a Common Article 3 situation throughout and never examined the international armed conflict aspects. There seems no doubt that there was an armed conflict of sufficient intensity to amount to a Common Article 3 situation beginning on the evening of 25 March 1971. But, the rest of the Geneva Conventions of 1949, and Hague law in treaty and/or custom, clearly applied from the moment the conflict became internationalised when there was sufficient Indian involvement, which was definitely the case when the Indian forces actively engaged in armed activities in the conflict, and probably even earlier given the extent of their assistance to, and control over, the Mukti Bahini. In these matters too, the Tadic case is critical, although here it is also the Appeal Judgement that must be consulted. $^{228}$

\subsubsection{War Crimes: Section 3(2)(d). The International Crimes (Tribunals) Act 1973 As Amended defines war crimes as:}

violation of laws or customs of war which include but are not limited to murder, illtreatment or deportation to slave labour or for any other purpose of civilian population in the territory of Bangladesh; murder or ill-treatment of prisoners of war or persons on the seas, killing of hostages and detenues, plunder of public or private property, wanton destruction of cities, towns or villages, or devastation not justified by military necessity.

This text is almost taken word-for-word from the IMT Nuremberg Statute ("detenues" and references to Bangladesh are added).

\section{The Nature of the Armed Conflicts}

The first issue to raise is the nature of the armed conflict. The "laws and customs of war" are rooted in old notions of State sovereignty that have traditionally drawn a line between international armed conflict, which is a matter of legitimate concern for the international community, and non-international armed conflict (used interchangeably with the term 'armed conflict not of an international nature'), which has been viewed as an internal matter which is solely the business of the State concerned. Traditional rules such as those set out in the Regulations Annexed to Hague Convention IV of 1907 were premised on the-then reality of armed conflict as being about wars between States; it was then not considered proper to lay down rules for

${ }^{228}$ Tadić Appeal Judgement, supra note 138. 
non-international armed conflict as that was within a State's domestic jurisdiction. Adopted in 1949, Common Article 3 is the lone regulator of 'armed conflict not of an international character' in the 1949 Geneva Conventions treaty regime and its focus is on protecting the victims of conflict, namely those taking no active part in hostilities. It has been repeatedly confirmed as providing the core protections in non-international armed conflict and as being part of customary international law. ${ }^{229}$ The 1977 Additional Protocol II extended this, as did Additional Protocol I's Article 1(4) on wars of liberation, ${ }^{230}$ but regulation of internal conflicts remains rudimentary in comparison even though the gaps may be supplemented by human rights law. ${ }^{231}$

${ }^{229}$ Military and Paramilitary Activities in and against Nicaragua (Nicar. v. U.S.A.), 1986 I.C.J. Reports 13, 218 (Jun. 27) [hereinafter Nicaragua Judgement]. Here, the International Court of Justice held that Common Article 3 is an expression of fundamental general principles of humanitarian law which are legally valid, independent of any treaty basis. It reflects 'elementary considerations of humanity' and is thus a minimum yardstick and part of customary law. See also Tadić Decision on Jurisdiction, supra note 186, - $99,98,102,116,134$.

${ }^{230}$ Protocol Additional to the Geneva Conventions of 12 August 1949, and Relating to the Protection of Victims of International Armed Conflicts, art 1(4), Jun. 8, 1977, 1125 U.N.T.S. 3 [hereinafter Additional Protocol I]. ("Armed conflicts in which peoples are fighting against colonial domination and alien occupation and against racist regimes in the exercise of their right of self-determination" fall within the remit of the protocol and the four Geneva Conventions. It is not expressly stated, but implicit that they are therefore to be considered international armed conflicts, because Additional Protocol I only applies in international armed conflicts.)

${ }^{231}$ Protocol Additional to the Geneva Conventions of 12 August 1949, and Relating to the Protection of Victims of Non-International Armed Conflicts, art 1(1), Jun. 8, 1977, 1125 U.N.T.S. 609 [hereinafter Additional Protocol II] (The threshold for a "non-international armed conflict" is higher than what is required for "armed conflicts not of an international character' in Common Article 3 of the Geneva Conventions, supra note 1, they do not apply to

situations of internal disturbances and tensions, such as riots, isolated and sporadic acts of violence and other acts of a similar nature, as not being armed conflicts" but only to "armed conflicts which take place in the territory of a High Contracting Party between its armed forces and dissident armed forces or other organised armed groups which, under responsible command, exercise such control over a part of its territory as to enable them to carry out sustained and concerted military operations and to implement this Protocol.)The ICRC includes as internal disturbances those confrontations that may be brief or chronic, and which may give rise to lasting humanitarian problems. Internal disturbances may take place without any government intervention to restore order. Disturbances sometimes take the form of clashes between factions, without any direct State participation. See Marion Harroff-Tavel, Internal Violence, 294 INT'L REV. RED CROSS 195 (1993). 
There is no denying that Article 1(4) and its attendant Article 44(3) were controversial. Even so, the provisions were the result of majority vote, ending a process of negotiation that formally began in 1974 and unofficially began years earlier as the right to self-determination came to be a mighty weapon in struggles for national liberation. Additional Protocol I in its entirety was signed by 62 States at the Diplomatic Conference. ${ }^{232}$ Professor Cassese points out that when the provision was put to the vote in 1977, 87 voted in favour, 1 against and 11 abstained; Israel was the only State that rejected the provision. ${ }^{233}$ Those who did not vote in favour did so because they questioned the political and legal ramifications of the rule. Cassese argues that in 1977, an emergent rule was crystallised when the previously objecting European States accepted it: "The acceptance of Article 1 testified to the formation of a rule binding on all the States participating in the conference (regardless of whether they ratified the Protocol) save for Israel". ${ }^{234}$

The reservations that have been entered on articles dealing with national liberation movements are primarily concerned with limiting the scope so that secession by minority groups and terrorism are not made lawful. In fact, the majority of those reservations underline that loosening of the combatancy provisions in Article 44(3) is limited, and most reservations expressly recognised the necessity for the provision to apply in occupied territories. ${ }^{235}$ Wilson points out that the governments who opposed or abstained did so "because the criteria were arbitrary and subjective and because they feared that such a provision would lead to the unequal and partial application of jus in bello. No delegation suggested that the use of force for self-deter-

232 ADAM ROBERTS \& RICHARD GUELFF, DOCUMENTS ON THE LAWS OF WAR 498 (3rd ed., 2001).

233 ANTONIO CASSESE, SELF-DETERMINATION OF PEOPLES: A LEGAL RE-APPRAISAL 278 (1995).

${ }^{234} \mathrm{Id}$

${ }^{235}$ See for example, the reservations of Italy and France to Article 44(3): the situation that it describes can only take place in occupied territory; the reservations of Canada, Germany and New Zealand on the same article were that it applied only in occupied territories and Article 1(4) situations. See Richard Baxter, The Duty of Obedience to the Belligerent Occupant, 28 BRIT. Y.B. INT'L L. 235 (1950). 
mination was itself illegitimate." 236 She cites how the Egyptian delegate, representing the developing world, spoke of how international practice "on the universal, regional and bilateral levels had established beyond doubt the international character of wars of national liberation". ${ }^{237}$ Greece and Australia also spoke in such terms, without challenge from any State. ${ }^{238}$ So, given the concerns to prevent secessionist wars in 1977, is it nevertheless possible to put forth a persuasive argument that that prior to the 1977 Additional Protocols, and specifically at the critical date of March 1971, wars of national liberation were already regulated in customary international law by the rules of international armed conflict?

State practice at the United Nations in the 1960s and 1970s leading up to the diplomatic conference that resulted in the adoption of Additional Protocol I reveals a line of resolutions, albeit contested ones, on the legal status of wars of national liberation as international armed conflicts, and the entitlement of national liberation fighters to combatant and Prisoner-of-War treatment under the Geneva Conventions 1949 if captured. The adoption of the resolutions suggests that for some States, the humanitarian protections of the conventions applied regardless of ratification and type of conflict, thus pointing to the possible evolution of an opinio juris necessary for a customary rule or general principle. ${ }^{239}$

The first line to explore is that of the status of the conflict. On the facts, it is unconvincing to argue that Bangladesh came into existence with Sheikh Mujibur's 7 March 1971 speech, for the extant materials about the realities on the ground did not meet the objective standards of international law on statehood, buttressed that the reality that no State recognised its existence until India did at a very advanced stage of the conflict when it had become a direct participant in hostilities

\footnotetext{
${ }^{236}$ HEATHER A WILSON, INTERNATIONAL LAW AND THE USE OF FORCE BY NATIONAL LIBERATION MOVEMENTS 128 (1988).

${ }^{237} I d$.

238 CASSESE, supra note 233, at 278.

${ }^{239}$ Legality of the Threat or Use of Nuclear Weapons, Advisory Opinion, 1996 I.C.J. Reports 225, 70 (Jul. 8, 1996) [hereinafter Nuclear Weapon Advisory Opinion] ("[A] series of resolutions may show the gradual evolution of the opinio juris required for the establishment of a rule of law").
} 
and the winds of war had already turned. ${ }^{240}$ That national liberation movements have come to be regarded as combatants in international armed conflicts has been the result of the collapse of colonial empires, the experiences of the Second World War and the influx of newly independent former colonies, many of which had to use force in order to achieve the right to self-determination. This restructuring of the international community enabled the passing of resolutions such Resolution 1514 (XV) of 1960, the Declaration on the Granting of Independence to Colonial Countries and Peoples. ${ }^{241}$ This provided that the use of force to prevent the exercise of the right to selfdetermination is unlawful: "all armed action or repressive measures of all kinds directed against dependent peoples shall cease in order to enable them to exercise...their right to complete independence". ${ }^{242}$ This is not to suggest that these resolutions were uncontroversial, for the issue of whether the legitimacy of the struggle meant could lead to the legitimacy of the use of force was generally contested by the former and remaining colonial powers. General Assembly Resolution 2105 (XX) of 20 December 1965 "recognises the legitimacy of the struggle by peoples under colonial rule to exercise their right to selfdetermination and independence and invites all states to provide material and moral assistance to the national liberation movements in colonial territories". ${ }^{243}$ In 1970, the Declaration on Principles of International Law (Resolution 2625 (XXV) of 24 October 1970), the General Assembly unanimously proclaimed that

[e]very State has the duty to refrain from any forcible action which deprives peoples referred to above in the elaboration of the present principle of their right to selfdetermination and freedom and independence. In their actions against, and resistance to, such forcible action in pursuit of the exercise of their right to self-deter-

${ }^{240}$ Montevideo Convention on Rights and Duties of States, art 1, Dec. 26, 1933, 16 L.N.T.S. 19, reprinted in 28 A.J.I.L., Supp. 75.

${ }^{241}$ Declaration on the Granting of Independence to Colonial Countries and Peoples, G.A. Res. 1514, U.N. GAOR, 15th Sess., Supp. No. 16, at 66-67, U.N. Doc. A/4684 (Dec. 14, 1960).

${ }^{242} I d ., \bullet 4$.

${ }^{243}$ Implementation of the Declaration on the Granting of Independence to Colonial Countries and Peoples, G.A. Res. 2105 (XX), 10, U.N. Doc A/RES/2105 (XX) (Dec. 20, 1965) (adopted by 74 votes for, 6 votes against, 27 abstentions and 10 not-voting (total voting membership: 117)). 
mination, such peoples are entitled to seek and to receive support in accordance with the purposes and principles of the Charter. ${ }^{244}$

This resolution certainly does not specifically provide national liberation movements with a right to use force, but its deliberate ambiguity reveals the desire to avoid dealing with the issue head-on. In Resolution 2708 (XXV) of 14 December 1970, the General Assembly reaffirmed "its recognition of the legitimacy of the struggle of the colonial peoples and peoples under alien domination to exercise their right to self-determination and independence by all means at its disposal'. ${ }^{245}$ The 1970 s saw more such resolutions of wider import covering use of force by those seeking to exercise the right to selfdetermination in colonial situations as well as those under alien subjugation. One such was resolution 3103 (XXVIII) which reaffirmed "the legitimacy of peoples' struggle for liberation from colonial and foreign domination and alien subjugation by all available means, including armed struggle."246 Resolution 3246 (XXIX) called upon all States not just to recognise the right to self-determination and independence of all those under colonial, foreign or alien subjugation, but also to "offer them moral, material and other forms of assistance in their struggle to exercise fully their inalienable right to self-determination and independence". ${ }^{247}$ Others include Resolutions

${ }^{244}$ Declaration on Friendly Relations between States, supra note 204,1 .

${ }^{245}$ Implementation of the Declaration on the Granting of Independence to Colonial Countries and Peoples, G.A. Res. 2708 (XXV), $\uparrow$ 5, U.N. Doc. A/RES/ 2708 (XXV) (Dec. 14, 1970) (adopted by 94 votes for, 5 votes against, 22 abstentions and 7 not-voting (total voting membership: 127)) (emphasis added).

${ }^{246}$ Basic Principles of the Legal Status of the Combatants Struggling Against Colonial and Alien Domination and Racist Regimes, G.A. Res. 3103 (XXVIII), 1 , U.N. Doc. A/RES/3103 (XXVIII) (Dec. 12, 1973) (adopted by 83 votes for, 13 votes against, 19 abstentions and 20 not-voting (total voting membership: 135)).

${ }^{247}$ Importance of the Universal Realization of the Right of Peoples to SelfDetermination and of the Speedy Granting of Independence to Colonial Countries and Peoples for the Effective Guarantee and Observance of Human Rights, G.A. Res. 3246 (XXIX), ๆ 2, U.N. Doc. A/RES/3246 (XXIX) (Dec. 4, 1974) (adopted by 107 votes for, 1 vote against, 20 abstentions and 10 not-voting (total voting membership: 138)). 
3070 (XXVIII), ${ }^{248} 3328$ (XXIX) ${ }^{249}$ and 3481 (XXX), ${ }^{250}$ all of which culminated in the consensus 1974 Declaration on the Definition of Aggression, which obviously came after the Bangladesh war was over. The 1974 Declaration, having outlined what amount to acts of aggression, closes with the caveat that none of its provisions can "in any way prejudice the right to self-determination, freedom and independence...particularly peoples under colonial and racist regimes or other forms of alien domination: nor the right of these peoples to struggle to that end and to seek and receive support, in accordance with the principles of the Charter and in conformity with the abovementioned Declaration [on Friendly Relations]". ${ }^{251}$

The second line of exploration in this matter of national liberation wars as international armed conflict is the status of captured 'freedom fighters'. Were they to be treated as ordinary criminals under domestic law or as Prisoners-of-War benefitting from the protections of the Geneva Conventions 1949? Resolution 2396 (XXIII) dealing with South Africa demanded that the population of South Africa as a whole should be able to exercise its right to self-determination, and that as their struggle was legitimate, freedom fighters there should be treated as Prisoners-of-War under the terms of international law, namely the Third Geneva Convention of $1949 .{ }^{252}$ Other examples of resolutions calling for application of the Geneva Conventions in

${ }^{248}$ Importance of the Universal Realization of the Right of Peoples to SelfDetermination and of the Speedy Granting of Independence to Colonial Countries and Peoples for the Effective Guarantee and Observance of Human Rights, G.A. Res. 3070 (XXVIII), U.N. Doc. A/RES/3070 (XXVIII) (Nov. 30, 1973) (adopted by 97 votes for, 5 votes against, 28 abstentions and 5 not-voting (total voting membership: 135)).

${ }^{249}$ Implementation of the Declaration on the Granting of Independence to Colonial Countries and Peoples, G.A. Res. 3328 (XXIX), U.N. Doc. A/RES/3328 (XXIX) (Dec. 16, 1974) (adopted by 118 votes for, 0 votes against, 10 abstentions and 10 not-voting (total voting membership: 138)).

${ }^{250}$ Implementation of the Declaration on the Granting of Independence to Colonial Countries and Peoples, G.A. Res. 3481 (XXX), U.N. Doc. A/RES/3481 $(\mathrm{XXX})($ Dec. 11, 1975) (adopted by 108 votes for, 3 votes against, 15 abstentions and 18 not-voting (total voting membership: 144)).

${ }^{251}$ Definition of Aggression, supra note 205, art 7.

252 The Policies of Apartheid of the Government of South Africa, G.A. Res 2396 (XXIII), U.N. Doc. A/RES/2396 (XXIII) (Dec. 2, 1968) (adopted by 85 votes for, 2 votes against, 14 abstentions and 25 not-voting (total voting membership: 126)). 
national liberation struggles were ${ }^{253}$ all of which dealt with wars of national liberation in the Portuguese African territories and called for application of the Third and Fourth Conventions. The States that participated in the International Conference on Human Rights in Tehran in 1968 approved Resolution XXIII which called for those fighting minority racist regimes or colonial regimes to, if detained, be treated as Prisoners of War or political prisoners. ${ }^{254}$ Resolution VIII called for the treatment of captured freedom fighters as Prisoners of War as per Geneva Convention III. ${ }^{255}$ This was reiterated in General Assembly Resolution 2621 (XXV) of 12 October 1970 which also claimed Prisoner of War treatment for freedom fighters under detention. ${ }^{256}$ The Secretary General's Second Report on Human Rights in Armed Conflict in 1970, reviewed the protection given by United Nations human rights instruments in armed conflicts and inter alia, suggested that Geneva Convention III should apply to freedom fighters and recommended amendment of the treaty to cover national liberation struggles. ${ }^{257}$ One of the most important of the line of normative resolutions in the matter of liberation fighters, that came after the Bangladesh war was over, was Resolution 3103 (XXVIII) of 12 December 1973 on Basic Principles of the Legal Status of Combatants Struggling against Colonial and Alien Domination and Racist Regimes. ${ }^{258}$ This drew from the numerous earlier appeals of the General Assembly to colonial powers and those occupying foreign territories as well as racist regimes to "ensure the application to the fighters for freedom and self-determination of the provisions of the Geneva Convention relative to the Treatment of Prisoners of War of 12 August 1949, and the Geneva Convention relative to the Protection of Civilian Persons in Time of War of 12 August 1949". It stressed that struggles against colonial and alien domination and racist regimes

${ }^{253}$ Question of Territories under Portuguese Administration, G.A. Res 2707 (XXV), U.N. Doc. A/RSE/2707 (XXV) (Dec. 14, 1970) (adopted by 94 votes for, 6 votes against, 16 abstentions and 11 not-voting (total voting membership: 127)).

${ }^{254}$ International Conference on Human Rights, Tehran, Resolution XXIII (May 12, 1968).

255 International Conference on Human Rights, Tehran, Resolution VIII (May 12, 1968).

${ }^{256}$ Programme of Action for the Full Implementation of the Declaration on the Granting of Independence to Colonial Countries and Peoples, G.A. Res 2621 (XXV), U.N. Doc. A/RES/2621 (XXV) (Oct. 12, 1970) (adopted by 86 votes for, 5 votes against, 15 abstentions and 21 not-voting (total voting membership: 127)).

257 The Secretary-General, Respect for Human Rights in Armed Conflicts: Report of the Secretary-General, ๆ 197-199, UN Doc A/8052 (Sept. 18, 1970).

${ }^{258}$ See supra, note 246. 
are to be regarded as international armed conflicts in the sense of the 1949 Geneva Conventions and the legal status envisaged to apply to the combatants in the 1949 Geneva Conventions and other international instruments is to apply to the persons engaged in armed struggles against colonial and alien domination and racist regimes.

Such persons, if captured "are to be accorded the status of prisoners of war" and their treatment should be in accordance with the provisions of Geneva Convention III.

For both these streams - the status of liberation wars and the status of liberation fighters - it is clear that these many but highly controversial resolutions do not suffice to form the state practice and opinio juris necessary to prove the existence of a customary rule in 1971 whereby struggles of liberation pursuant to the right to selfdetermination could be covered by the rules of international armed conflicts, let alone be considered as international armed conflicts. If the State practice can be found to show that in 1971, States actually treated such conflicts, and captured 'freedom fighters' as protected by the Geneva Conventions as Prisoners-of-War, then the argument becomes more convincing. Without that, it is untenable.

\section{The Applicability of Customary Rules to Armed Conflicts not of an International Character}

The extent to which the customary rules are applicable to armed conflict not of an international nature has been controversial. Common Article 3 sets down minimum standards in a non-international armed conflict. In 1986, the International Court of Justice in Nicaragua recognised Common Article 3 as reflecting elementary considerations of humanity and affirmed that it affords protection in not just non-international armed conflict but also international armed conflict. ${ }^{259}$ In Tadić, the ICTY Appeals Chamber accepted this as correct, holding that "at least with respect to the minimum rules in Common Article 3, the character of the conflict is irrelevant."260 These two critical decisions came after the Bangladesh war of independence. And, over in Cambodia, one of the findings of the Group of Experts for Cambodia was that the only international regulation of internal

${ }^{259}$ Nicaragua Judgement, supra note 229, ศฯ 218-219 (drawing from Corfu Channel (U.K. v. Alb.), 1949 I.C.J. Reports 4, 215) [hereinafter Corfu Channel Judgement].

${ }^{260}$ Tadić Decision on Jurisdiction, supra note 186, 102. 
conflict during the Khmer Rouge years (1975-1999) was Common Article $3 .{ }^{261}$ Hague law on the means and methods of war did not apply.

As is well known, the Nuremberg tribunal dealt with violations of the "laws and customs of war" in international armed conflict, but not non-international armed conflict. ${ }^{262}$ Likewise, the Charter of the International Military Tribunal for the Far East and Control Council Law No. 10 were also dealing with international armed conflict. Created in 1993, the ICTY also has a war crimes definition relying on the "laws and customs of war", although it was differently constructed. The Bangladeshi tribunal would be well advised to examine closely how the "laws and customs of war" were handled in Tadic and other cases. Until the ICTY's Tadic Decision on Jurisdiction in 1995 , it was disputed that war crimes could be committed in a noninternational armed conflict. ${ }^{263}$ This is because there is a difference between rules that are prescriptive and rules that carry penal sanction. Until the Tadic decision clarified the state of customary law, the only clear penal sanctions were for violations of the Grave Breaches provisions of the Geneva Conventions 1949 and the violations of the "laws and customs of war", which could only arise in international armed conflicts. This takes us back to the problem of the status of the armed conflict in East Pakistan. In international law, this was a Common Article 3 situation that become internationalised through India's participation and then a full international armed conflict when India engaged in acts of armed force against Pakistan (this preceded the Pakistani attacks on India). So, jurisdiction over the early months of the war, including the armed attacks against Dhaka, is in doubt for this provision. This underscores the important role that the Penal Code could have played in this legislation.

\section{The Content of the "Law and Customs of War" in 1971}

What exactly were the "laws and customs of war" that applied in 1971? According to the Nuremberg tribunal's famous judgment, "by 1939 these rules laid down in the [Regulations annexed to Hague Convention IV] were recognised by all civilised nations, and were regarded as being

${ }^{261}$ Cambodia Experts Report, supra note 167, 75.

262 This was also recognised in the ICJ EAST PAKISTAN 1971 REPORT, supra note 5, at 59 .

${ }^{263}$ See e.g., Yoram Dinstein, The International Law of Civil Wars and Human Rights, 6 ISR. Y.B. HUM. RTS 62 (1976); Michael Bothe, War Crimes in Non International Armed Conflicts, in war CRIMES IN INTERNATIONAL LAw 293 (Yoram Dinstein \& Mala Tabory eds., 1996). 
declaratory of the laws and customs of war". ${ }^{264}$ The Martens Clause, incorporated into the preamble of Hague Convention IV of 1907 and providing a minimum protection of "the principles of the law of nations, as they result from the usages established among civilised peoples, from the laws of humanity, and the dictates of the public conscience" is also firmly part of that body of law. ${ }^{265}$ These regulations had in fact been influenced by the 1863 Lieber Code, used in the American Civil War and the Franco-Prussian War and amount to what the International Court of Justice in Corfu Channel described as "elementary considerations of humanity". 266

Since Nuremberg, the content of the "laws and customs of war" has expanded. In its Nuclear Weapons Advisory Opinion, the International Court of Justice declared these principles of humanity to be "intransgressible principles of customary law" which bind all States whether or not they have ratified the Hague and Geneva Conventions. ${ }^{267}$ The court saw that at the heart of such provisions were two overriding considerations:

The first is aimed at the protection of the civilian population and civilian objects and establishes the distinction between combatants and non-combatants; states must never make civilians the object of attack and must consequently never use weapons that are incapable of distinguishing between civilian and military targets. According to the second principle, it is prohibited to cause unnecessary suffering to combatants: it is accordingly prohibited to use weapons causing them such harm or uselessly aggravating their suffering. In application of that second principle, states do not have unlimited freedom of choice of means in the weapons they use. ${ }^{268}$

In its Wall Advisory Opinion, the International Court of Justice reiterated that "the provisions of the Hague Regulations have become part of customary law" (a point on which all participants in that proceeding ( 15 countries made oral submissions) were agreed) ${ }^{269}$ It went further "In the Court's view, these rules incorporate obligations which are

${ }^{264}$ IMT Judgement, supra note 194, at 248. This was confirmed in Nuclear Weapons Advisory Opinion, supra note 239, 75 and Wall Advisory Opinion, supra note $132,89$.

${ }^{265}$ Wall Advisory Opinion, supra note 132, $78,84$.

266 Corfu Channel Judgement, supra note 259, at 22.

${ }^{267}$ Nuclear Weapons Advisory Opinion, supra note 239, 79, cited with approval in Wall Advisory Opinion, supra note 132, 157.

268 Nuclear Weapons Advisory Opinion, supra note 239, ๆ 78.

${ }^{269}$ Wall Advisory Opinion, supra note 132, 189. 
essentially of an erga omnes character." 270 It has also been held that "[t]he one definite rule of international law, however, is that the direct and deliberate bombing of non-combatants is in all circumstances illegal". ${ }^{271}$ Other rules that are so fundamental as to apply in any armed conflict have been judicially identified:

protection of civilians from hostilities, in particular from indiscriminate attacks, protection of civilian objects, in particular cultural property, protection of all those who do not (or no longer) take active part in hostilities, as well as prohibition of means of warfare proscribed in international armed conflicts and ban of certain methods of conducting hostilities. ${ }^{272}$

The Geneva Conventions 1949 came after the Nuremberg and Tokyo trials. They were designed to apply to States parties. But they have been confirmed as being part of customary international law. ${ }^{273}$ Common Article 3 has been confirmed as applying in all armed conflicts. $^{274}$ The question for the Bangladeshi tribunal to answer is whether this was already so in 1971. The 1995 Tadic Decision on Jurisdiction is helpful for shedding further light on this matter. The notion of "laws and customs of war" was also used in the ICTY Statute, although its provision is differently formulated. ${ }^{275}$ The judges of the Appeals Chamber had to interpret the provision in the light of the Statute, and ultimately concluded, on the basis of a textual, teleological and logical construction, that the provision was:

a general clause covering all violations of humanitarian law not falling under Article 2 or covered by Articles 4 or 5, more specifically: (i) violations of the Hague law on international conflicts; (ii) infringements of provisions of the Geneva Conventions other than those classified as "grave breaches" by those Conventions; (iii) violations of common Article 3 and other customary rules on internal conflicts; (iv) violations of agreements binding upon the parties to the conflict, considered qua treaty law, i.e., agreements which have not turned into customary international law. ${ }^{276}$

It is very important to stress that this decision cannot be relied on as is, for it is built on the particular architecture of the ICTY Statute, which

\footnotetext{
${ }^{270} I d .$, - 157.

271 Tadić Decision on Jurisdiction, supra note 186, 100.

${ }^{272}$ Id., 127.

${ }^{273}$ Confirmed as customary in the Report of the UNSG under UNSC Res 808, supra note 100, ๆ $35,37$.

${ }^{274}$ Confirmed as applicable in all armed conflicts in Nicaragua Judgement, supra note 223, 218; Tadić Decision on Jurisdiction, supra note 186, ฯ 89, 98, 102, 116, 134.

275 Tadić Decision on Jurisdiction, supra note 186, 87.

276 Id., 99.
} 
divided out the "laws and customs of war" and the Grave Breaches of the Geneva Conventions 1949. While the decision is very helpful, even essential, for those dealing with the Bangladeshi provision, it has to be handled with great care and with a thorough understanding of international criminal law and the international law of armed conflict. It will not apply as is; the Bangladeshi law also has to be read in its own context. Following that logic of reading the structure of the legislation, and for the reasons set out in the following sections, ${ }^{277}$ it seems that this provision was not mean to include the Geneva Conventions of 1949.

\section{Criminalisation of Breaches of Common Article 3}

There is another issue that must be raised here. The complex process of analysing a provision such as Section 3(2)(d) is not just a matter of identifying which positive rules contained in treaties had passed into customary international law by 1971 . Those prohibitions must also, if violated, have triggered individual criminal responsibility. ${ }^{278}$ This is well explained by the ICTY Trial Chamber in Vasiljević, which determined that a Trial Chamber:

must further satisfy itself that the criminal conduct in question was sufficiently defined and was sufficiently accessible at the relevant time for it to warrant a criminal conviction and sentencing under the criminal heading chosen by the Prosecution, in this case "violence to life and person". From the perspective of the nullum crimen sine lege principle, it would be wholly unacceptable for a Trial Chamber to convict an accused person on the basis of a prohibition which, taking into account the specificity of customary international law and allowing for the gradual clarification of the rules of criminal law, is either insufficiently precise to determine conduct and distinguish the criminal from the permissible, or was not sufficiently accessible at the relevant time. A criminal conviction should indeed never be based upon a norm which an accused could not reasonably have been aware of at the time of the acts, and this norm must make it sufficiently clear what act or omission could engage his criminal responsibility. ${ }^{279}$

This is a tricky problem for the 1971 war. The International Commission of Jurists Report correctly identified the problem inherent in Common Article 3: it does not expressly penalise acts in contravention

${ }^{277}$ See in particular, the sections on Criminalisation of Breaches of Common Article 3 and "Violations of any Humanitarian Rules Applicable in Armed Conflicts Laid Out in the Geneva Conventions of 1949".

${ }^{278}$ See Theodor Meron, International Criminalization of Internal Atrocities, 89 AM. J. INT'L L. 554 (1995).

${ }^{279}$ Vasiljević Trial Judgement, supra note 177, 193. 
of its provisions. The Report recognised the controversy, but ultimately argued that war crimes should at least include breaches of Common Article 3. However, the reasoning was inadequate. There was no textual analysis of Common Article 3, even in the section on the Geneva Conventions, to sustain the recommendation that a national court set up to try offenders under international penal law could take jurisdiction over violations of the provision. ${ }^{280}$ The report referred to the intentions of the United Nations, and not the intentions of the drafters of the Geneva Conventions 1949, of which Common Article 3 is part. There was also no examination of State practice or opinio juris to sustain the argument for an evolution in the customary international rule allowing for the prosecution of violations of Common Article 3 as a war crime. In light of the above, the International Commission of Jurists' position on Common Article 3 is unsustainable. ${ }^{281}$

I do however believe that there is ground to argue for the criminalisation of violations of Common Article 3 by 1971, in itself and by linking it to the 'fundamental general principles of humanitarian law' which are undeniably part of the "laws and customs of war". In 1986, when the International Court of Justice held that Common Article 3 applied in all conflicts and reflected 'fundamental general principles of humanitarian law', it did not comment on whether this meant that breaches carried criminal sanction, or that this would amount to war crimes carrying international criminal responsibility. ${ }^{282}$ Professor Meron and others had doubts, although in his seminal 1995 article in the American Journal of International Law, Professor Meron cited some examples of growing evidence of the criminalisation of violations of Common Article 3. ${ }^{283}$ Confirmation that breaches of Common Article 3 involved international criminality finally came with its appearance in the Statute of the ICTR in 1994, and even more so in 1995, when the ICTY's Appeals Chamber issued a landmark decision holding that breaches of Common Article 3 amounted to breaches of the laws and customs of war, and were thus prosecutable under Article 3 of the ICTY Statute. According to the Appeals Chamber in

${ }^{280}$ See ICJ EAST PAKISTAN 1971 REPORT, supra note 5, at 53-54.

${ }^{281}$ See $i d$., at $53-54,57-58$.

282 Nicaragua Judgement, supra note 229, ๑ 218-219.

${ }^{283}$ See Meron, supra note 278; Bothe, supra note 263, at 293-204; Denise Plattner, The Penal Repression of Violations of International Humanitarian Law Applicable in Non-International Armed Conflicts, 30 INT'L REV. RED Cross 4 (1990); Theodor Meron, Note and Comment: On the Inadequate Reach of Humanitarian and. Human Rights Law and the Need for a New Instrument (1983) 77 AM. J. INT'L L. 589 (1983). 
Tadić, "many elements of international practice show that States intend to criminalise serious breaches of customary rules and principles on internal conflicts". It drew on examples such as from the Nigerian civil war and from relevant provisions of the 1956 US Army Field Manual which suggested that war crimes, described as "every violation of the law of war", include infringement of Common Article 3 as well as from the British Manual of Military Law (1958). ${ }^{284}$

Of great relevance to the formation of opinio juris to the effect that violations of general international humanitarian law governing internal armed conflicts entail the criminal responsibility of those committing or ordering those violations are certain resolutions unanimously adopted by the Security Council. Thus, for instance, in two resolutions on Somalia, where a civil strife was under way, the Security Council unanimously condemned breaches of humanitarian law and stated that the authors of such breaches or those who had ordered their commission would be held "individually responsible" for them. ${ }^{285}$

The Appeals Chamber concluded that:

[a]11 of these factors confirm that customary international law imposes criminal liability for serious violations of Common Article 3, as supplemented by other general principles and rules on the protection of victims of internal armed conflict, and for breaching certain fundamental principles and rules regarding means and methods of combat in civil strife. ${ }^{286}$

In addition to State practice and opinio juris, the Appeals Chamber in Tadic noted that violations of Common Article 3 entailed individual criminal responsibility regardless of the type of conflict because "[p]rinciples and rules of humanitarian law reflect 'elementary considerations of humanity' widely recognised as the mandatory minimum for conduct in armed conflicts of any kind. No one can doubt the gravity of the acts at issue, nor the interest of the international community in their prohibition.",287

This reasoning covered the law that applied to the conflict in the Balkans which began in 1991. Can it be applied to a situation 20 years earlier? The examples cited, did include pre-1971 ones. Those seeking to argue this will have to show that there was the State practice and opinio juris to support there being individual criminal responsibility

\footnotetext{
${ }^{284}$ Tadić Decision on Jurisdiction, supra note 186, 131.

${ }^{285} I d$., 133.

${ }^{286} I d$., ๆ 134.

${ }^{287}$ Id., 129.
} 
for violations of Common Article 3 in 1971. The fact that there had in 1971 not been any international prosecutions for violations of the "fundamental principles of humanity" in non-international armed conflicts does not in itself mean that these customary rules may not be treated as carrying penal sanction. The Nuremberg precedent in relation to war crimes is that acts need not be expressly criminalised, but it suffices if they are prohibited in international law (in that case by the "laws and customs of war", most particularly the Regulations Annexed to Hague Convention IV). Compliance with the principle of legality means going beyond those "relaxed attitudes", to borrow from Professor Jescheck. The core acts would need to be criminalised by domestic law or according to the general principles of law recognised by the community of nations. That international law imposes duties and liabilities upon individuals as well as upon States was recognised long before the IMT's judgement, and in the words of the military tribunal in High Command, it would be "an utter disregard of reality...legal shadow-boxing" if there were no means of ensuring compliance with such fundamental principles of international law. ${ }^{288}$ It is only by punishing individuals who commit such crimes that the provisions of international law can be enforced. ${ }^{289}$

Ultimately, to succeed with an argument that in 1971, violations of Common Article 3 were already criminalised in custom and could be prosecuted as violations of the laws and customs of war in non-international armed conflict, it will have to be shown that there was the State practice and opinio juris to support there being individual criminal responsibility for violations of Common Article 3 in 1971. Absent that, Common Article 3 cannot properly be used to prosecute anyone.

This situation clearly shows how important it was to have retained the Bangladesh Penal Code, under which acts falling through the many loopholes of international criminal law could be prosecuted. This was, ironically, used in the 1972 Collaborators Act.

\subsubsection{2 "Violations of any Humanitarian Rules Applicable in Armed Conflicts Laid Out in the Geneva Conventions of 1949”. On a plain reading, it is not clear what this provision means, since all the rules in the Geneva Conventions of 1949 are "humanitarian" (Geneva law) as opposed to being of jus in bello (Hague law) nature such as are \\ ${ }^{288}$ See United States v. Von Leeb et al., XI Trials of War Criminals 462-697 (U.S.A. Military Tribunal, 1948), XII Law Reports of Trials of War Criminals 1, 72 (U.S.A. Military Tribunal 1949) [hereinafter High Command Case]. \\ ${ }^{289}$ IMT Judgement, supra note 194, at 221.}


contained in the Regulations annexed to Hague Convention IV of 1907. Contextually, this provision comes after the 'war crimes' provision, and the reference to "humanitarian rules" and the "Geneva Conventions" gives the impression that the drafters may actually have intended the 'war crimes' provision to cover Hague law and this second provision to cover Geneva law.

Contrary to what the text suggests, there is not individual criminal responsibility for every single breach of every single rule in the Geneva Conventions of 1949. The hundreds of rules in the Geneva Conventions range from prohibition of murdering civilians to rules specifying the kind of identity card that a Prisoner-of-War is supposed to have and rules on censoring of mail. In general terms, there three categories of rules in the Geneva Conventions 1949 - fundamental provisions, violations of which are called Grave Breaches of the Geneva Conventions; violations of the Geneva Conventions that are serious, but do not amount to Grave Breaches; and the rest.

It is only violation of the fundamental rules that carry individual criminal responsibility in international criminal law, and can be prosecuted as Grave Breaches of the Geneva Conventions. These are international crimes. Grave Breaches are perpetrated when there is an international armed conflict ${ }^{290}$ and someone commits the following acts against persons or property protected under the provisions of the relevant Geneva Convention:

(a) wilful killing;

(b) torture or inhuman treatment, including biological experiments;

(c) wilfully causing great suffering or serious injury to body or health;

(d) extensive destruction and appropriation of property, not justified by military necessity and carried out unlawfully and wantonly;

(e) compelling a prisoner of war or a civilian to serve in the forces of a hostile

(f) power;

(g) wilfully depriving a prisoner of war or a civilian of the rights of fair and regular

(h) trial;

(i) unlawful deportation or transfer or unlawful confinement of a civilian;

(j) taking civilians as hostages.

${ }^{290}$ Tadić Decision on Jurisdiction, supra note 186, 84. ("Notwithstanding the foregoing, the Appeals Chamber must conclude that, in the present state of development of the law, Article 2 of the Statute only applies to offences committed within the context of international armed conflicts.") 
We see this confirmed in Article 50 of Geneva Convention I, Article 51 of Geneva Convention II, Article 130 of Geneva Convention III and Article 147 of Geneva Convention IV. With Grave Breaches come a host of responsibilities, namely the obligation to enact any legislation necessary to provide effective penal sanctions for persons committing, or ordering to be committed, any of the grave breaches, and the obligation to search for persons alleged to have committed, or to have ordered to be committed, such grave breaches, and shall bring such persons, regardless of their nationality, before its own courts. The High Contracting Party may also, if it prefers, and in accordance with the provisions of its own legislation, hand such persons over for trial to another High Contracting Party concerned, provided such High Contracting Party has made out a prima facie case.

It is obviously possible to prosecute Grave Breaches of the Geneva Conventions 1949 , in relation to the international armed conflict phase of the 1971 war. On a reading in accordance with Article 31 of the VCLT, Grave Breaches would fall within the notion of "humanitarian rules applicable in armed conflicts laid out in the Geneva Conventions of 1949". The tribunal will have to determine a 'critical date' from which the Indian involvement was such as to internationalise the Common Article 3 conflict. It is clear that the massacres of the intellectuals in Dhaka just prior to the surrender would fall within the period of the international armed conflict, and could be prosecutable as Grave Breaches (although it may be felt to be more appropriately to be charged as a crime against humanity, even genocide, depending on the evidence that is available).

Can violations of Common Article 3 be Grave Breaches? In 1994, Professor Bassiouni's commission argued that breaches of Common Article 3 were not Grave Breaches of the Geneva Conventions. ${ }^{291}$ One year later in Tadic, the ICTY's Appeals Chamber majority

${ }^{291}$ Commission of Experts (Former Yugoslavia), Final Report of the Commission of Experts (Former Yugoslavia) Established pursuant to Security Council Resolution 780, 42, U.N. Doc. S/1994/674 (May 27, 1994):

The treaty law designed for internal armed conflict is in common article 3 of the Geneva Conventions, Additional Protocol II of 1977, and article 19 of the 1954 Hague Convention for the Protection of Cultural Property in the Event of Armed Conflict. These legal sources do not use the terms 'grave breaches' or 'war crimes'. Further, the content of customary law applicable to internal armed conflict is debatable. As a result, in general, unless the parties to an internal armed conflict agree otherwise, the only offences committed in internal armed 
(Judge Abi-Saab with a strong dissent) noted that there was flux but took the view that the law as it stood did not recognise the notion of Grave Breaches in non international armed conflict. It cited with "satisfaction" the Amicus Curiae submission of the USA, which argued that Grave Breaches could be committed in non-international armed conflict, and that national courts were taking the view that the grave breaches system may operate regardless of the whether the armed conflict was international or internal. ${ }^{292}$ Yet it found that "at the present state of development of the law", Grave Breaches as contained in Article 2 of its Statute, only applied to offences committed in the context of international armed conflict. The majority of the judges did, as this paper has already demonstrated, find that breaches of Common Article 3 would amount to violations of the "laws and customs of war" further to the construction of the ICTY Statute. Serious but non-grave breaches would also fall therein.

Each of the Geneva Conventions also requires High Contracting Parties to take measures necessary for the suppression of all acts contrary to the provisions of its provisions other than the Grave Breaches. ${ }^{293}$ They are not Grave Breaches and are not necessarily international crimes (Professor Meron correctly points out that they may amount to violations of the laws and customs of war $^{294}$ ). The prosecution, under this Bangladeshi provision, of such violations of the Geneva Conventions packaged up as if they were international crimes, is going to be very problematic. Even today, they are not automatically international crimes. This is a very different situation

\section{Footnote 291 continued}

conflict for which universal jurisdiction exists are 'crimes against humanity' and genocide, which apply irrespective of the conflicts' classification.

See also Theodor Meron, War Crimes in Yugoslavia and the Development of International Law, 88 AM. J. INT'L L. 78, 80 (1994); International Committee of the Red Cross [ICRC], Preliminary Remarks on the Setting-Up of an International Tribunal for the Prosecution of Persons Responsible for Serious Violations of International Humanitarian Law Committed in the Territory of the Former Yugoslavia, 9 , Doc. DDM/JUR/442 b (Mar. 25, 1993).

292 Tadić Decision on Jurisdiction, supra note 186, ๆ 83.

${ }^{293}$ For example, Article 146 of Geneva Convention IV, supra note 1, requires that "Each High Contracting Party shall take measures necessary for the suppression of all acts contrary to the provisions of the present Convention other than the grave breaches defined in the following Article."

${ }^{294}$ See Meron, supra note 278, at 242. 
from Article 4 of the Statute of the Special Court for Sierra Leone, ${ }^{295}$ which is geared for a particular type of war crime (described as "serious violations of international humanitarian law": a. Intentionally directing attacks against the civilian population as such or against individual civilians not taking direct part in hostilities; $b$. Intentionally directing attacks against personnel, installations, material, units or vehicles involved in a humanitarian assistance or peacekeeping mission in accordance with the Charter of the United Nations, as long as they are entitled to the protection given to civilians or civilian objects under the international law of armed conflict; c. Conscripting or enlisting children under the age of 15 years into armed forces or groups or using them to participate actively in hostilities. These, it will be obvious, are offences of the Hague law variety, involving the jus in bello. These would, if we were to draw an analogy with Bangladesh, fall under its "war crimes" provision.

\subsection{5 "Any Other Crimes Under International Law"}

This standalone catch-all provision is noteworthy. Its vagueness and the absence of the necessary specificity required to bring a criminal charge against a person are remarkable. The principle of specificity is part of the principle of legality, which must surely be a general principle of law. It requires that crimes are defined as precisely or specifically as possible so that a potential perpetrator is aware of the elements constituting the prohibited conduct, and can regulate his or her behaviour accordingly. In Vasiljević, an ICTY Trial Chamber held that the offense must be defined "with sufficient clarity for it to have been foreseeable and accessible, taking into account the specificity of customary international law." ${ }^{296}$ The principle extends to the role of the court in assessing criminal provisions; this is captured in Article 22(2) of the ICC Statute: "The definition of a crime shall be strictly construed and shall not be extended by analogy. In case of ambiguity, the definition shall be interpreted in favour of the person being investigated, prosecuted or convicted." As Professor Cassese acknowledges, there are specificity problems with much of international criminal law (for example, the Geneva Conventions use the term 'torture' but do not define it), and the principle is not fully applied in international law. ${ }^{297}$ Professor Jescheck cautioned that, in

${ }^{295}$ Statute of the Special Court for Sierra Leone, Aug. 14, 2000, 2178 U.N.T.S. 138, S.C. Res. 1315, U.N. Doc. S/RES/1315 (Aug. 14, 2000) [hereinafter SCSL Statute].

\footnotetext{
296 Vasiljević Trial Judgement, supra note 177, 198.

297 CASSESE, supra note 197, at 41.
} 
relation to customary international law, general principle of law and case law, the principle can only serve "as a guiding doctrine, to be observed when interpreting the rules produced by these sources of law". 298 But to prosecute people on the basis of "any other crimes under international law" is really going too far.

A similar situation - and it is nowhere near as extreme - to this provision in the International Crimes (Tribunals) Act 1973 As Amended is the "other inhumane acts" provision in the crimes against humanity definitions of the ICTY and ICTR Statutes. An ICTY Trial Chamber held that this notion of "other inhumane acts" was deliberately designed as a residual category, as it was felt to be undesirable for this category to be exhaustively enumerated, that would merely create opportunities for evasion of the letter of the prohibition. ${ }^{299}$ That does not get around the problem that this provision lacks specificity. The technique that is used to deal with this sort of situation is the ejusdem generis approach, which is interpretation-by-analogy. And that is also controversial; it is prohibited by the aforementioned Article 22(2) of the ICC Statute. Using this method, the term "other inhumane acts" is interpreted in the light of the other provisions, leading to the conclusion that is does not mean any old "inhumane act" but those which are of the same level of gravity as the identified crimes, such as persecution and extermination. ${ }^{300}$ Dissatisfaction with the lack of specificity exemplified in these examples has resulted in much more careful drafting of the ICC Statute. The following 'catch-all' provisions illustrate how a list can be left open-ended, without violating the principle of specificity:

- Rape, sexual slavery, enforced prostitution, forced pregnancy, enforced sterilization, or any other form of sexual violence of comparable gravity; $;^{301}$ and

${ }^{298}$ Jescheck, supra note 101, at 41. See also Prosecutor v. Karemera et al., Case No. ICTR-98-44-T, Decision on the Preliminary Motions by the Defence of Joseph Nzirorera, Édouard Karemara, Andre Rwamakuba and Mathieu Ngirumpatse Challenging Jurisdiction in Relation to Joint Criminal Enterprise, 43 (May 11, 2004) ("that, given the specificity of international criminal law, the principle of legality does not apply to international criminal law to the same extent as it applies in certain national legal systems").

${ }^{299}$ Prosecutor v. Kupreskić et al., Case No. IT-95-16-T, Judgement, 563 (Jan. $14,2000)$.

${ }^{300}$ See BASsiounI, supra note 161, at 331 (elaborating on the use of the principle).

${ }^{301}$ ICC Statute, supra note 98, art 7(1)(g) (emphasis added). 
- Other inhumane acts of a similar character intentionally causing great suffering, or serious injury to body or to mental or physical health. ${ }^{302}$

The reason why these particular catch-alls are acceptable is because it is made clear that the sorts of other unlisted crimes have to be of similar type and magnitude of the preceding crimes. Notice is clearly given of the kind of prohibited criminal conduct. This is not the case with the provision in the International Crimes (Tribunals) Act As Amended. There can be no foreseeability with a provision like this, it is virtually an 'anything goes' provision. It treats international law like an open book and allows the Prosecutor to draw in anything that he wants as a "crime under international law". The accused is not on notice of what he is supposed to have done wrong until the Prosecutor pulls the mysterious "any other crimes under international law" out of the hat. In the face of such a provision, and the naked will of the Legislature that it reveals, it does not seem at all fair or just for a court of law to apply the ejusdem generis approach.

That being said, the consequences of this provision may actually not be that bad. How does one identify what international crimes are? The ICTY Appeals Chamber in Tadic identified four principles to guide the identification of an international crime: (1) the infringement of a rule of the international law of armed conflict; (2) the customary or treaty law character of the crime; (3) the 'seriousness' of the violation of humanitarian law and (4) the establishment of individual criminal liability by the rule in question. ${ }^{303}$ In Norman, a Trial Chamber of the Special Court for Sierra Leone went through the process of trying to ascertain the customary status of the crime of child military recruitment, the critical date being 1996, and the result very controversial. ${ }^{304}$

In an earlier section, I observed that the ancillary crime of direct and public incitement to commit genocide has not been expressly provided for in the 1973 Act and appears not to be covered by the enumerated modes of responsibility. In 1971, this was probably a "crime in violation of international law", i.e. in line with the Tadic test, particularly being in violation of the Genocide Convention and the customary prohibition against genocide and carrying individual

\footnotetext{
${ }^{302}$ ICC Statute, supra note 98, art 7(1)(k) (emphasis added).

303 Tadić Appeal Judgement, supra note 138, 94.

${ }^{304}$ Prosecutor v. Norman, Case No. SCSL-2004-14-AR72(E), Decision on Preliminary Motion Based on Lack of Jurisdiction (Child Recruitment), ฯ 9 30-53 (May 31, 2004).
} 
criminal responsibility. ${ }^{305}$ This provision could perhaps be used to enable prosecution and convictions for direct and public incitement to commit genocide. In 1971, there were probably no other "international crimes" than piracy, genocide and its ancillary crimes, crimes against humanity and war crimes. Piracy seems not to be relevant to the Bangladeshi situation. One would have to conduct further research to be certain, but it is not unreasonable to posit that slavery was, in 1971, already prohibited under customary

${ }^{305}$ See e.g. Reservations to the Convention on the Prevention and Punishment of Genocide, Advisory Opinion, 1951 I.C.J. Report 15, 26 (May 28) ("The origins of the Convention show that it was the intention of the United Nations to condemn and punish genocide as "a crime under international law".... The first consequence arising from this conception is that the principles underlying the Convention are principles which are recognized by civilized nations as binding on States, even without any conventional obligation..." (emphasis added)); G.A. Res. 96(I), U.N. Doc. A/RES/ 96(I) (Dec. 11, 1946) ("Affirms that genocide in a crime under international law....and for the commission of which the principals and accomplices are punishable"); Eichmann District Court Judgement, supra note 81, at 11. In 1988, Hannikainen considered genocide as a "clear" case of international crimes under customary international law punishable in domestic court (see LAURI HANNIKAINEN, PEREMPTORY NORMS (JUS COGENS) IN INTERNATIONAL LAW: HISTORICAL DEVELOPMENT, CRITERIA, PRESENT STATUS 285-286 (1988)). See also Buzzacott v Minister for the Environment and Others, 120 I.L.R. 354, 18 (Austl, Fed. Ct., 1999):

I accept that the prohibition of genocide is a peremptory norm of customary international law, giving rise to a non-derogatable obligation by each nation State to the entire international community. This is an obligation independent of the [Genocide Convention]. It existed before the commencement of that Convention in January 1951, probably at least from the time of the United Nations General Assembly resolution in December 1946 (emphasis added).

On incitement to commit genocide, a Trial Chamber of the ICTR has noted prosecution and conviction of incitement in international criminal law since the IMT Nuremburg (see Akayesu Trial Judgement, supra note 213, 950 ):

Perhaps the most famous conviction for incitement to commit crimes of international dimension was that of Julius Streicher by the Nuremberg Tribunal for the virulently anti-Semitic articles which he had published in his weekly newspaper Der Stürmer. The Nuremberg Tribunal found that: "Streicher's incitement to murder and extermination, at the time when Jews in the East were being killed under the most horrible conditions, clearly constitutes persecution on political and racial grounds in connection with War Crimes, as defined by the Charter, and constitutes a Crime against Humanity".

On this point, see also Prosecutor v. Nahimana, Barayagwiza and Ngeze, Case No. ICTR-99-52-T, Trial Judgement, 978 est. seq. (Dec. 3, 2003) (also known as the "Media" case). 
international law. But that does not mean it was also a "crime under international law" carrying individual criminal responsibility. Torture is problematic, for despite a prohibition of the act in the UDHR, European Convention on Human Rights, ${ }^{306}$ Geneva Conventions 1949 and the not-yet-in-force ICCPR, the international anti-torture movement only started in response to events in Latin America after the Bangladesh war was over. The foundational international activity came with General Assembly Resolution 3059 (XXVIII) of $1973^{307}$ adopted unanimously, which revealed the international community's concerns to reinforce the illegality of this practice and came out of a growing awareness that there was a need for greater international regulation; and Resolution 3218 (XXIX) of 6 November $1974,{ }^{308}$ that sought specific information from States on the practice of torture and saw the General Assembly move towards standard-setting and doing more than simply issuing declarations. It followed four potentially normative lines: the possibility of developing the rules against torture and ill-treatment, safeguards against arbitrary arrest and detention, professional ethics for police and analogous officers, professional ethics for medical personnel. Resolution 3452 (XXX), the Declaration against Torture, would only come on 9 December $1975 .{ }^{309}$ So torture as a stand-alone international crime in 1971 seems most unlikely. Terrorism would seem to be a possibility. There were already some anti-terrorist conventions in force at the time of the Bangladesh war of independence. But these outlawed certain acts, and relied on States Parties to adopt implementing legislation to prosecute accused persons in domestic law. It was not envisaged that they would be tried in an international process before an international court. Acts, such as those in violation of the Convention for the Suppression of Unlawful Seizure of Aircraft, signed at The Hague

306 The European Convention for the Protection of Human Rights and Fundamental Freedoms, Nov. 4, 1950, 213 U.N.T.S. 222 (entered into force Sep. 3, 1953, as amended by Protocols 1-14).

307 Question of Torture and other Cruel Inhuman or Degrading Treatment or Punishment, G.A. Res 3059 (XXVIII), U.N. Doc. A/RES/3059 (Nov. 2, 1973).

308 Torture and other Cruel Inhuman or Degrading Treatment or Punishment in relation to Detention and Punishment, G.A. Res. 3218 (XXIX), U.N. Doc. A/RES/ 3218 (Nov. 6, 1974).

${ }^{309}$ Declaration on the Protection of All Persons from Being Subjected to Torture and other Cruel, Inhuman or Degrading Treatment of Punishment, G.A. Res 3452 (XXX), U.N. Doc. A/RES/3452 (XXX) (Dec. 9, 1975). 
on 16 December $1970,{ }^{310}$ were not "crimes in violation of international law".

\subsection{Modes of Responsibility}

The Bangladesh Penal Code 1860 - which was also the law at the time of the war of liberation under a different name - does provide for modes of responsibility. In addition to detailed elaborations of the prohibited forms of direct commission of crime, that code also contains detailed chapters on abetment (Ch. V), criminal conspiracy (Ch. VA), and attempts (Ch. XXIII). Although the Penal Code has not been expressly ousted, particular provisions on modes of responsibility that are included in the International Crimes (Tribunals) Act 1973 As Amended, suggest that the Penal Code is not to apply.

With the great benefit of hindsight, one would have wished to see something like Article 7(1) of the ICTY Statute, providing that " 1 . A person who planned, instigated, ordered, committed or otherwise aided and abetted in the planning, preparation or execution of a crime referred to in articles $2-5$ of the present Statute, shall be individually responsible for the crime." Article 25 of the ICC Statute is also very clear. The modes of perpetration of crimes under the Statute are by way of committing; ordering, soliciting, inducing; aiding, abetting or otherwise assisting; common purpose ${ }^{311}$ direct and public incitement to commit genocide and inchoate offences.

Subsection 1 of Section 3 of the International Crimes (Tribunals) Act 1973 As Amended describes the personal jurisdiction of the tribunal as being over those who committed or have committed certain crimes in the territory of Bangladesh. The drafters do detail the types of criminal conduct to be covered, but these are actually different concepts. The 1973 Act does not address direct perpetration, such as, to take an example, Article 25(3)(a) of the ICC Statute, which criminalises the acts of a person who "commits such a crime, whether as an individual, jointly with another or through another person,

${ }^{310}$ Convention for the Suppression of Unlawful Seizure of Aircraft, Dec. 16, 1970, 860 U.N.T.S. 105 (entered into force Oct. 14, 1971).

311 ICC Statute, supra note 98, art 25(3)(d):

Such contribution shall be intentional and shall either: (i) Be made with the aim of furthering the criminal activity or criminal purpose of the group, where such activity or purpose involves the commission of a crime within the jurisdiction of the Court; or (ii) Be made in the knowledge of the intention of the group to commit the crime. 
regardless of whether that other person is criminally responsible". In terms of individual responsibility, the following are provided in the 1973 Act. Section 3(2)(g) criminalises "attempt abetment or conspiracy to commit any such crimes". Strangely, 'commission' of crime is not included among the enumerated list of modes of responsibility. One could of course stretch to argue that Joint Criminal Enterprise $(' \mathrm{JCE})^{312}$ is a form of conspiracy or even abetment under the Bangladeshi law, but if one were to rely on the international cases, there will have to be an evaluation of whether JCE existed in 1971, and what its content was. Also, the ICTY jurisprudence on JCE roots it in the notion of 'commit', which is not in the relevant provisions, namely Sections 3(2)(g) and (h). Section 3(2)(h) criminalises "complicity in or failure to prevent commission of any such crimes". Subject to Section 4(2) below, there is no provision on ordering. There is also nothing on planning, instigation or incitement. How-

312 The term 'Joint Criminal Enterprise' (also known as "JCE") was invented at the ICTY to describe different types of co-perpetration that had evolved in the World War II jurisprudence. That jurisprudence conceptualised co-perpetration in different ways, using different phrases. JCE has been held to be a form of 'commission' of crime under Article 7(1) of the ICTY Statute, supra note 156, and Art 6(1) of the ICTR Statute, supra, note 168, which are not limited to physical perpetration. In Tadic, the ICTY Appeals Chamber divided the jurisprudence into 3 categories, all of which have 3 features: a plurality of persons, a common plan and participation in the common plan (Tadić Appeal Judgement, supra note 138, 185-229, especially 227). The first 2 types of JCE are straightforward. All co-defendants, acting pursuant to a common design, possess the same criminal intention (JCE 1 - Basic JCE); and concentration camp cases - groups of persons acting pursuant to a concerted plan (JCE 2 - Systemic JCE). What is controversial is the third form, extended JCE, whereby the accused did not personally commit the crime, or it was not a component of the common plan, but was a predictable consequence of execution of the common plan and the accused was either reckless or indifferent to that risk (Tadic Appeal Judgement, supra note 138, ๆ 210, 229).

In Cambodia, the ECCC is still grappling with the issue. After having asked for amicus curiae from experts, the Pre-Trial Chamber refused to allow the first accused to be tried for his membership in a JCE or a conspiracy to commit all 15,000 killings at S-21 Centre and Choeng Ek, on the grounds that the prosecutor's request was vague and long overdue. The co-investigating judges did not conduct their work with JCE specifically in mind, and the attempt to expand the type of conduct attributable to Duch was not fair as he had the right to be informed of the charges at the investigative stage. They could have taken this decision without asking for amicus briefs, and so dodged the substantive issue. But JCE is still pending in the second case, where the prosecution is at time of writing making submissions on JCE for a multi-accused case (see Prosecutor v. Kaing (Alias "Duch"), Case No. 001/18-072007-ECCC/OCIJ (PTC 02), Decision on Appeal Against Closing Order Indicting Kaing Guek Eav Alias “Duch” (Dec. 5, 2008)). 
ever, embedded in the definition of the crime against peace are: "planning, preparation, initiation or waging a war of aggression..." Under Section 4(1), "[w]hen any crime as specified in Section 3 is committed by several persons, each of such person is liable for that crime in the same manner as if it were done by him alone". This underlines in the individual nature of criminality, a person will be judged by his or her own conduct.

What of command responsibility? In Dhaka, one is told of the abiding significance of the command responsibility standard set down in the Yamashita decision, ${ }^{313}$ and that the highly progressive and expertly drafted law of 1973 provides for this in Section 4(2). Command responsibility, it is said, is critical for prosecuting the crimes in question. But, the standard of almost-strict liability imposed on that Japanese general have long been rightly criticised for being both unjust and having no legal basis at that point in time. ${ }^{314}$ Command responsibility was not applied in that form to the German war accused or any other Japanese, just to General Yamashita. We have seen, over and

313 The military court held that where "vengeful actions are widespread offences and there is no effective attempt by a commander to discover and control the criminal acts, such a commander may be held responsible, even criminally liable." (Trial of General Tomoyuki Yamashita, IV Law Reports of Trials of War Criminals 1, 35 (U.S.A. Military Tribunal 1949)). General Yamashita, by his position and authority, must have had a certain degree of knowledge of the activities committed in Manila by his troops and the naval forces tactically assigned to him. There was no need for a linkage to the actual crimes.

${ }^{314}$ In Re Yamashita, 327 U.S. 1, 28 (1946). Justices Murphy and Rutledge complained about the absence of fair trial as guaranteed under the Constitution and the violation of the principle of legality. They found there was no serious attempt to charge or prove a recognised violation of the laws of war; the accused was not even charged with personal participation in the acts of atrocity, or ordering or condoning their commission; the prosecution couldn't even show he had knowledge of the crimes:

[The prosecution] simply alleged that he unlawfully disregarded and failed to discharge his duty as a commander to control the operations of the members of his command, permitting them to commit the acts of atrocity. The recorded annals of warfare and the established principles of international law afford, not the slightest precedent for such a charge.

Overall, they concluded it was unfair to have charged him with failure to control the Japanese forces when the US had done everything to destroy and disorganise his lines of communication and his ability to maintain effective control of his personnel. See also MICHAEL WALZER, JUST AND UNJUST WARS: A MORAL ARGUMENT WITH HISTORICAL ILLUSTRATIONS 319-322 (1977); A. FRANK REEL, THE CASE OF GENERAL YAMASHITA (1971); BASSIOUNI, supra note 161, at 426 (recognising the controversy of this "notorious" trial). 
over again, that there is an obsession with the notion of command responsibility, which is a wrong categorisation for mass crimes where subordinates act the way their commanders want them to act. East Timor and Indonesia are particularly clear examples of how command responsibility does not work for system crimes. The commander is invariably going to be part of some kind of common plan and he conveys the objectives of the plan down the line. The doctrine of JCE, controversial as it is, does capture the bigger picture and the scheme of criminality within which the commander operates.

That being said, scrutiny of Section 4(2) reveals that it is a provision that is not known to international criminal law past or present, one that confuses the different modes of criminal responsibility:

Any commander or superior officer who orders, permits, acquiesces or participates in the commission of any of the crimes specified in section 3 or is connected with any plans and activities involving the commission of such crimes or who fails or omits to discharge his duty to maintain discipline, or to control or supervise the actions of the persons under his command or his subordinates, whereby such persons or subordinates or any of them commit any such crimes, or who fails to take necessary measures to prevent the commission of such crimes, is guilty of such crimes.

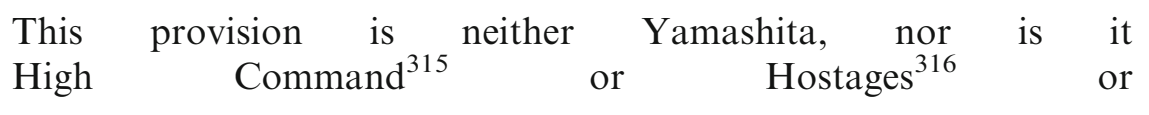

${ }^{315}$ See High Command Case, supra note 288. (A US Military Tribunal accepted the notion of command responsibility but not strict liability: 1. "In order for a commander to be criminally liable for the actions of his subordinates "there must be a personal dereliction" which "can only occur where the act is directly traceable to him or where his failure to properly supervise his subordinates constitutes criminal negligence on his part" tantamount to a wanton, immoral disregard of the action of his subordinates amounting to acquiescence." 2. "Under basic principles of command authority and responsibility, an officer who merely stands by while his subordinates execute a criminal order of his superiors which he knows is criminal violates a moral obligation under international law. By doing nothing he cannot wash his hands of international responsibility" (see High Command Case, supra note 288, at 76).)In short, the "should have known" standard "was unacceptable and not sufficient proof of actual knowledge. Crime must be evident". According to the court, there "must be a personal dereliction" (see High Command Case, above n. 288, at 76).

${ }^{316}$ United States of America v. Wilhelm List et al., XI Trials of War Criminals 1230-1319, VIII Law Reports of Trials of War Criminals 32 (U.S.A. Military Tribunal, 1948) [hereinafter Hostages Case]. Here, a US Military Tribunal accepted the notion of command responsibility. But it stated that a commander is "charged with notice of occurrences taking place within [occupied] territory" where he has received reports of crimes and he "fails to require and obtain complete information, the dereliction of duty rests upon him and he is in no position to plead his own dere- 
Toyoda $^{317}$ or Medina ${ }^{318}$ or the provisions on superior responsibility that were, 6 years later, to be adopted in Additional Protocol I to the 1949 Geneva Conventions. ${ }^{319}$ Command

\section{Footnote 316 continued}

liction as a defence." (see Hostages Case, supra note 316, at 71). Command responsibility requires actual receipt of information, and action where the commander is put on notice. Where, having been put on notice, a commander fails to "require and obtain complete information, the dereliction of duty rests upon him and he is in no position to plead his dereliction as a defence... want of knowledge of the contents of reports made to him is not a defence" (see Hostages Case, supra note 316, at 71).

${ }^{317}$ United States v. Soemu Toyoda, Judgement, Official Transcript of Record of Trial 4998-5007 (U.S.A., Military Tribunal sitting in Tokyo, Sept. 6, 1949):

[...] [I]f this accused knew, or should by the exercise of ordinary diligence have learned, of the commission by his subordinates, immediate or otherwise, of the atrocities proved beyond a shadow of a doubt before this Tribunal or of the existence of a routine which would countenance such, and, by his failure to take any action to punish the perpetrators, permitted the atrocities to continue, he has failed in his performance of his duty as a commander and must be punished" (see United States v. Soemu Toyoda, quoted in Delalić et al. Trial Judgement, supra note 136, 340).

${ }^{318}$ Instructions from the Military Judge to the Court Martial Members, United States of America v. Ernest Medina, in 2 THE LAW OF WAR - A DOCUMENTARY HISTORY 1729-1737 (Leon Friedmann ed., 1972) [hereinafter Medina Instructions]. The Military Judge in the case instructed the jury that in order to convict Medina of Command Responsibility, there had to be sufficient evidence of actual knowledge plus a wrongful failure to act.

Mere presence at the scene without knowledge will not suffice. That is, the commander-subordinate relationship alone will not allow an inference of knowledge. While it is not necessary that a commander actually see an atrocity being committed, it is essential that he know that his subordinates are in the process of committing atrocities or about to commit atrocities.

${ }^{319}$ Additional Protocol I, supra note 230, art 86(2) (Failure to Act): Superiors cannot escape liability for acts of subordinates if

they knew, or had information which should have enabled them to conclude in the circumstances at the time, that he was committing or was going to commit such a breach and if they did not take all feasible measures within their power to prevent or repress the breach.

See also Additional Protocol I, supra note 230, art 87 (Duty of Commanders):

1. The High Contracting Parties and the Parties to the conflict shall require military commanders, with respect to members of the armed forces under their command and other persons under their control, to prevent and, where 
responsibility is not, as has been done here, to be confused with individual criminal responsibility arising from ordering the commission of a crime, or ordering an act where there is a substantial likelihood that crimes would be committed in the course of that act. ${ }^{320}$ The provision also relies on a concept of "fails or omits to discharge his duty". What is the mental element: is it to be the almost-strict liability of Yamashita's "must have known" standard, or the "knew or ought to have known/had reason to know" concept that is actually what came out of the whole process of the post World War II trials, including the trials under Control Council Law No. 10 and the domestic trials held across Europe and Asia, and other trials such as Medina, and ultimately reflected in Additional Protocol I? Here is also contained the only reference to ordering in the Act, and it is limited to "any commander or superior officer". It seems to be the local civilian and paramilitary groups that are most likely to be targeted by Bangladeshi investigations and prosecutions: one could probably stretch the definition to make it include those with de facto command, whether military or civilian. ${ }^{321}$

\section{Footnote 319 continued}

necessary, to suppress and to report to competent authorities breaches of the Conventions and of this Protocol.

2. In order to prevent and suppress breaches, High Contracting Parties and Parties to the conflict shall require that, commensurate with their level of responsibility, commanders ensure that members of the armed forces under their command are aware of their obligations under the Conventions and this Protocol.

3. The High Contracting Parties and Parties to the conflict shall require any commander who is aware that subordinates or other persons under his control are going to commit or have committed a breach of the Conventions or of this Protocol, to initiate such steps as are necessary to prevent such violations of the Conventions or this Protocol, and, where appropriate, to initiate disciplinary or penal action against violators thereof.

${ }^{320}$ See Prosecutor v. Blaskić, Case No. IT-95-14-A, Appeal Judgement, $\uparrow$ ฯ 89-93 (Jul. 29, 2004). Note however that it also held that Article 7(1) subsumes Article 7(3). Thus, if an accused is found to have commits crimes under the individual criminal responsibility and command responsibility modes, a conviction must be entered under individual criminal responsibility (Article 7(1)) as it is the most direct form of responsibility.

${ }^{321}$ In customary international law, in determining if someone is a commander for the purposes of the doctrine of command responsibility, it is not a person's rank that counts, but whether a person had authority to issue orders to the subordinates, who were obliged to obey. It applies to civilians and military, State and non-State actors. See Prosecutor v. Aleksovski, Case No. IT-95-14/1-T, Judgement, ฯ 75-76 (Jun. 25, 1999); Delalić et al. Appeal Judgement, supra note 223, 197 ("the doctrine of superior 
One way to work in the actual definition of command responsibility that applied in 1971, would be to draw on Article 3(2)(h) which criminalises "complicity in or failure to prevent commission of any such crimes". Only certain persons have a duty to prevent commission of crime, and that includes military and civilian superiors. That being said, Article 3(2) is insufficient and Section 4(1) is an unsatisfactory provision that really must be replaced with a statement that reflects the actual state of international law in 1971.

These are the sorts of things that should have been tidied up in the review of the International Crimes (Tribunals) Act 1973 As Amended in 2009 .

\subsection{Defence Matters}

There is much of importance to the defence discussed in the following section on Rules of Procedure and Evidence, but there are some matters that are more appropriate dealt with separately.

\subsubsection{Defence Counsel}

The ICCPR, in Article 14, requires the accused has the right to a lawyer of his choice, with free legal assistance if he does not have the means to pay for it. The International Crimes (Tribunals) Act As Amended does

\footnotetext{
Footnote 321 continued

responsibility extends to civilian superiors only to the extent that they exercise a degree of control over their subordinates which is similar to that of military commanders").
}

See also Prosecutor v. Bagilishema, Case No. ICTR-95-1A-A, Appeal Judgement, 9 52 (Jul. 3, 2002) [hereinafter Bagilishema Appeal Judgement]:

$[\ldots][T]$ he establishment of civilian superior responsibility requires proof beyond reasonable doubt that the accused exercised effective control over his subordinates, in the sense that he exercised a degree of control over them which is similar to the degree of control of military commanders. It is not suggested that "effective control" will necessarily be exercised by a civilian superior and by a military commander in the same way, or that it may necessarily be established in the same way in relation to both a civilian superior and a military commander.

This does not mean that the control exercised by a civilian superior must be of the same nature as that exercised by a military commander.

It is sufficient that, for one reason or another, the accused exercises the required "degree" of control over his subordinates, namely, that of effective control.... The case law of the International Tribunals makes it mandatory to use the effective control test for both de jure and de facto superiors (see Bagilishema Appeal Judgement, $\uparrow$ 55). 
provide for defence counsel to be made available. Since this is a $100 \%$ domestic process, there is no provision for foreign defence counsel. But, under Section 12, where an accused person is not represented by counsel, the Tribunal may, at any stage of the case, "direct that a counsel shall be engaged at the expense of the Government to defend the accused person and may also determine the fees to be paid to such counsel". Obviously, this does not provide for the right of an accused person to have or choose his counsel; it gives the Tribunal the discretionary power to assign a particular counsel of its choice to the accused, and at "any stage of the case". There are always reasons to be concerned when counsel is imposed on an accused, rather than by choice. But, the reality is the right to counsel of choice is not an absolute right. Even if the accused is able to pay his own legal costs, he has to choose a lawyer who is entitled to appear before the court. If he cannot pay his own way, he will be limited by the rules of the body that pays the legal costs. For example, at the ICTY and ICTR, indigent accused (those who cannot pay for their own costs) may only choose counsel from a list provided by the Registrar of the court who is the paymaster on behalf of the UN. ${ }^{322}$

\subsubsection{Defences}

Following on from the deplorable practice established in the post World War II processes, this is a law that is silent on defences to be made available for the accused. In the 1973 law, there is not even a statement about the essential presumption of innocence in favour of the accused

${ }^{322}$ See e.g. ICTY Statute, supra note 156, art 21; ICTR Statute, above n. 168, art 20; Prosecutor v. Zejnil Delalić, Zdravko Mucić, Hazim Delić and Esad Landzo, Case No. IT-96-21-T, Decision on the Request by Accused Mucic for Assignment of New Counsel (Jun. 24, 1998); Prosecutor v Ntakirutimana, Case No. ICTR-96-10-T/ ICTR-96-17-T, Decision on the Motion by Accused to be Assigned New Counsel (Jun. 11, 1997). See also Crossaint v Federal Republic of Germany, App No. 13611/ 88 ECHR, 29 (Nov. 27, 2008), available at http://www.echr.coe.int/eng:

It is true that Article 6 para. 3 (c) (art 6-3-c) [of the ECHR] entitles "everyone charged with a criminal offence" to be defended by counsel of his own choosing. Nevertheless, and notwithstanding the importance of a relationship of confidence between lawyer and client, this right cannot be considered to be absolute. It is necessarily subject to certain limitations where free legal aid is concerned and also where, as in the present case, it is for the courts to decide whether the interests of justice require that the accused be defended by counsel appointed by them. When appointing defence counsel the national courts must certainly have regard to the defendant's wishes.... However, they can override those wishes when there are relevant and sufficient grounds for holding that this is necessary in the interests of justice. (citation omitted) 
(this is apparently because the presumption is implicit in the Bangladeshi criminal justice system, is a part of the criminal justice culture, and hence would always be in the minds of the judges). ${ }^{323}$ The Penal Code 1860 that was then applicable provides in detail for the defences are that available to an accused. Chapter IV contains general exceptions, and they cover mistake of fact, mistake of law, acts by a minor, acts by persons of unsound mind, intoxication, consent, and compulsion. There is also an entire section on the right of private defence (self-defence). The International Crimes (Tribunals) Act As Amended does not address the matter of the Penal Code 1860; it has not been expressly ousted. However, the law is not standalone, in the sense that it does refer to certain acts such as the Army Act 1952 which will continue to apply. This is not the case with the Penal Code 1860. It therefore seems that the defences in that code may not be available for the accused under this 1973 law. For the reasons already discussed, there is no way to challenge anything in the law on the basis of the Constitution.

In international criminal law today, there is a wide range of what are called "circumstances excluding responsibility" (the terminology has to balance the different approaches of the common and civil law traditions). The following are recognised in the Statute of the ICC: mental disease or defect; ${ }^{324}$ intoxication; ${ }^{325}$ self-defence; ${ }^{326}$ duress/ necessity; ${ }^{327}$ mistake of fact or law; ${ }^{328}$ alibi and superior orders. ${ }^{329}$ The official capacity of the accused is irrelevant. ${ }^{330}$ In the Bangladeshi law of 1973 as amended, there is only a provision covering official capacity and superior orders. Section 5 of the International Crimes (Tribunals) Act 1973 As amended provides as follows:

(1) The official position, at any time, of an accused shall not be considered freeing him from responsibility or mitigating punishment.

(2) The fact that the accused acted pursuant to his domestic law or to order of his Government or of a superior shall not free him

\footnotetext{
${ }^{323}$ Email from M. Shah Alam, Professor of the University of Chittagong (Sept. 5, 2009) (on file with the author).

${ }^{324}$ ICC Statute, supra note 98, art 31(1)(a).

${ }^{325}$ Id., art 31(1)(b).

${ }^{326} I d$. art 31(1)(c).

${ }^{327} I d$., art 31(1)(d).

${ }^{328} I d$., art 32.

${ }^{329} I d$., art 33.

${ }^{330} I d$., art 27.
} 
from responsibility, but may be considered in mitigation of punishment if the Tribunal deems that justice so requires. ${ }^{331}$

This is a very slight adaptation of the IMT Nuremberg formulation. In the then-and-present applicable domestic law, the equivalent provision is Section 76 of the 1860 Penal Code, which provides that it can be a defence for a person to have acted in good faith pursuant to law, or by mistake believed himself, in good faith, to be bound by law. The commentary on Section 76 illuminates with the following explicit illustration:

(a) $A$, a soldier, fires on a mob by the order of his superior officer, in conformity with the commands of the law. $A$ has committed no offence. (b) $A$, an officer of a Court of Justice, being ordered by that Court to arrest $Y$, and, after due enquiry, believing $Z$ to be $Y$, arrests $Z$. $A$ has committed no offence.

This raises a major problem. Superior orders were and are expressly available as a defence in the then-and-present applicable domestic law. But, for a certain category of person to be tried under the International Crimes (Tribunals) Act As Amended, this defence is not available. This is clearly unequal treatment before the law. It is compounded by the fact that these persons are also barred from making any constitutional challenges to the law.

Official acts are not controversial, but the correctness of relying on the IMT's superior orders provision for 1971 crimes is uncertain. Superior orders have long been a controversial issue in international law. Professor Jescheck stated that the IMT's claim in its judgement that the superior orders provision was in conformity with the law of all nations "cannot hold". ${ }^{332}$ As the Israeli Supreme Court held in Eichmann, when interpreting the superior orders provision in the IMT Statute,

It must be understood that this express provision was designed to defeat in advance any attempt by the Nazi criminals to resort to the respondeat superior plea to the point of carrying it ad absurdum, in view of the Fuehrerprinzip which, in the last analysis, made it possible to trace to Hitler alone the source of the satanic orders which resulted in the perpetration of the horrendous Nazi crimes, including that of the 'Final Solution'. ${ }^{333}$

\footnotetext{
${ }^{331}$ International Crimes (Tribunals) Act 1973 As Amended, supra note 79, Section 5.

332 Jescheck, supra note 101, at 46.

${ }^{333}$ Eichmann Supreme Court Judgement, supra note 81, at 316-317.
} 
The legal position has yoyo-ed from being a complete defence $^{34}$ or partial defence in $^{335}$ in the pre World War II years, to no defence at all in the Statutes of the IMTs Nuremberg and Tokyo as well as Control Council Law No. $10^{336}$

${ }^{334}$ LASSA OPPENHEIM, INTERNATIONAL LAW: A TREATISE 264 (1st ed., 1906) (Stating the rule in international law as being: "In case members of forces commit violations ordered by their commanders, the members may not be punished, for the commanders are alone responsible, and the latter may, therefore, be punished as war criminals on their capture by the enemy." [absolute defence]). The British and American Military Codes of the time recognised this defence of respondeat superior a superior order shall serve as a defence for a war crime committed in obedience to it. It is the one who made the order who will be criminally responsible for the subordinate's act [absolute defence].

${ }^{335}$ Military Penal Code 1872, s47 (Ger.). The Code provided for a qualified superior orders defence: there was no responsibility for a subordinate unless the subordinate knew, while committing the act, that the act as a misdemeanour or a crime. Made superiors responsible if they issued unlawful orders. [limited defence]. In the Llandovery Castle case before the Supreme Court of Leipzig:

$[\ldots][T][$ he subordinate obeying an order is liable to punishment, if it was known to him that the order of the superior involved the infringement of civil or military law.... It is certainly to be urged in favour of the military subordinates that they are under no obligation to question the order of their superior officer, and they can count upon its legality. But no such confidence can be held to exist, if such an order is universally known to everybody, including the accused, to be without any doubt whatever against the law. (The Landovery Castle Case [1921] Cmd. 1422 at 45, 2 Annual Digest of Public International Law Cases 436-438 (Ger. Reichsgericht 1921).)

Also held that one can assume an order that looks ok on the face of it is consistent with the law. In the Dover Castle case, before the Supreme Court of Leipzig: “...a subordinate who acts in conformity with orders...is liable...when he knows [compliance would] involve a civil or military crime or misdemeanour". (The Dover Castle Case [1921] Cmd. 1422 at 42, 2 Annual Digest of Public International Law Cases 429-430 (Ger. Reichsgericht 1921).) These cases set down a loose 'ought to have known' or 'actually knew' standard for the subordinate. It is no defence where the order was so blatant that he knew or ought to know that the instruction was unlawful [limited defence].

${ }^{336}$ Charter of the IMT Nuremberg, supra note 93, art 8. See also Control Council Law No. 10, supra note 82, art 4(b): "The fact that any person acted pursuant to the order of his Government or of a superior does not free him from responsibility for a crime, but may be considered in mitigation". 


to a partial defence in the post World War II case law
such as Hostages, ${ }^{337}$ High Command, ${ }^{338}$ Calley ${ }^{339}$ and

${ }^{337}$ Hostages Case, supra note 316 , at $50-52$. The court accepts that there is a rule that superior orders is not a defence to a criminal act, but it qualifies it by emphasising lawful and unlawful orders:

It cannot be questioned that acts done in time of war cannot involve any criminal liability on the part of officers or soldiers if the acts are prohibited by the conventional or customary rules of war. Implicit obedience to orders of superior officers is almost indispensable to every military system. But this implies obedience to lawful orders only. If the act pursuant to a superior's order be murder, the production of the order will not make it any less so. It may mitigate but it cannot justify the crime. We are of the view, however, that if the illegality of the order was not known to the inferior, and he could not reasonably have been expected to know of its illegality, no wrongful intent necessary to the commission of the crime exists, and the inferior will be protected. But the general rule is that [soldiers] are bound to obey only the lawful orders of commanding officers and they cannot escape criminal liability by obeying a command, which violates international law and outrages fundamental concepts of justice (see Hostages Case, supra note 316, at 50-52).

A soldier is a "reasoning agent" and not an automaton that does nothing more than follow orders given. While a soldier is obliged to follow the orders of a superior, which includes the passing on of orders to subordinates, obedience is requisite only when the orders received (and perhaps passed on) are lawful. The defence of superior orders is not available where the order given, and subsequently passed on was so done knowing that the same was criminal.

${ }^{338}$ See also High Command Case, supra note 288, at 73-74:

Military commanders in the field with far reaching military responsibilities cannot be charged under international law with criminal participation in issuing orders which are not obviously criminal or which they are not shown to have known to be criminal under international law." "Whenever there is a manifestly illegal order involved, the subordinate is no longer entitled to rely on the order given by the superior and must accordingly refuse to obey such orders or run the risk of liability.

${ }^{339}$ See also the Medina Instructions, supra note 318; Soldiers are trained to follow orders, and special attention is given to obedience of orders on the battlefield. Military effectiveness depends upon obedience to orders.

On the other hand, the obedience of the soldier is not the obedience of an automaton. A soldier is a reasoning agent, not a machine, but a person. The law takes these factors into account in assessing criminal responsibility for acts only in compliance with illegal orders". "The acts of a subordinate done in compliance with a lawful order given him by his superior are excused and impose no criminal liability unless the superior's order is one which a man of ordinary sense and understanding would, under the circumstances, known to 
Finta, ${ }^{340}$ and back to no defence in the ICTY and ICTR Statutes $^{341}$ and culminating in the highly nuanced provision adopted for the ICC. ${ }^{342}$ In such a situation, if one were to respect the presumption of innocence and the doctrine of favor rei, one should give the accused the benefit of the doubt and allow him/her to use the superior orders defence. It is particularly so since the domestic law at the time, the Penal Code 1860, which continues to apply to this day, allows the superior orders defence.

\subsubsection{Inducements to Confess}

Section 15 is an inducement to confess, a form of plea bargain agreement.

Footnote 339 continued

be unlawful, or if order in question is actually known to the accused to be unlawful.

${ }^{340}$ See R v. Finta, supra note 141, at 706. The Canadian Supreme Court accepted that superior orders is a defence, subject to the manifest illegality test, and the moral choice test (which actually goes into Duress):

[...] [T]he defences will not be available when the orders in question were manifestly unlawful. Even where the orders were manifestly unlawful, the defence of obedience to superior orders and the peace officer defence will be available in those circumstances were the accused had no moral choice as to whether to follow the orders. That is to say, there was such an air of compulsion and threat to the accused that the accused had no alternative but to obey the orders. As an example, the accused could be found to have been compelled to carry out the manifestly unlawful order in circumstances were the accused would be shot he or she failed to carry out the orders." The case considered when an order is manifestly unlawful: "It must be one that offends the conscience of every reasonable, right thinking person; it must be an order which is obviously and flagrantly wrong. The order cannot be in a gray area or be merely questionable; rather, it must be blatantly and obviously wrong.

${ }^{341}$ See ICTY Statute, supra note 156, art 7(4); ICTR Statute, supra note 168, art 6(4). ${ }^{342}$ ICC Statute, supra note 98, art 33:

1. The fact that a crime within the jurisdiction of the Court has been committed by a person pursuant to an order of a Government or of a superior, whether military or civilian, shall not relieve that person of criminal responsibility unless: (a) The person was under a legal obligation to obey orders of the Government or the superior in question; (b) The person did not know that the order was unlawful; and (c) the order was not manifestly unlawful.

2. For the purposes of this article, orders to commit genocide or crimes against humanity are manifestly unlawful. 
(1) At any stage of the trial, a Tribunal may with a view to obtaining the evidence of any person supposed to have been directly or indirectly concerned in, or privy to, any of the crimes specified in Section 3, tender a pardon to such person on condition of his making a full and true disclosure of the whole of the circumstances within his knowledge relative to the crime and to every other person concerned, whether as principal or abettor, in the commission thereof.

(2) Every person accepting the tender under this section shall be examined as a witness in the trial.

(3) Such person shall be detained in custody until the termination of the trial. ${ }^{343}$

It is described as a "pardon", but there seems to be some confusion here. If the person is not yet convicted, it would be an amnesty from prosecution; if the person in question is someone already convicted, then it would be a pardon. Section 15 is actually a provision that predates Article 16 of the South African Interim Constitution of 1994, which led to the notorious 'amnesty for the truth' provision that has come to be the defining feature of South Africa's Truth and Reconciliation Commission. ${ }^{344}$ The roots of this amnesty, in the Interim Constitution, were what ultimately saved it when the Constitutional Court ruled on the challenge brought by the Azanian People's Organisation. ${ }^{345}$ Mahomed DP, for the Constitutional Court, held that:

[32]... The amnesty contemplated is not a blanket amnesty against criminal prosecution for all and sundry, granted automatically as a uniform act of compulsory statutory amnesia. It is specifically authorised for the purposes of effecting a constructive transition towards a democratic order. It is available only where there is a full disclosure of all facts to the Amnesty Committee and where it is clear that the particular transgression was perpetrated during the prescribed period and with a political objective committed in the course of the conflicts of the past. That objective has to be evaluated having regard to the careful criteria listed in s 20(3) of the Act,

${ }^{343}$ International Crimes (Tribunals) Act 1973 As Amended, supra note 79, Section 15 .

${ }^{344}$ See Promotion of National Unity and Reconciliation Act 1995, arts. 18-20 (S. Afr.) (on the procedure for granting amnesty: Where an applicant has "made a full disclosure of all relevant facts, it shall grant amnesty in respect of that act, omission or offence").

${ }^{345}$ Azanian Peoples Organisation (AZAPO) and Others v. President of the Republic of South Africa and Others, 1996 (4) SA 671 (CC); 1996 (8) B.C.L.R. 1015 (CC); 131 I.L.R. 492 (S. Afr.). 
including the very important relationship which the act perpetrated bears in proportion to the object pursued.

[50] In the result, I am satisfied that the epilogue to the Constitution authorised and contemplated an "amnesty" in its most comprehensive and generous meaning so as to enhance and optimise the prospects of facilitating the constitutional journey from the shame of the past to the promise of the future. Parliament was, therefore, entitled to enact the Act in the terms which it did.... The choice of alternatives legitimately fell within the judgment of the lawmakers. The exercise of that choice does not, in my view, impact on its constitutionality. It follows from these reasons that s 20(7) of the Act is authorised by the Constitution itself and it is unnecessary to consider the relevance and effect of s 33(1) of the Constitution. ${ }^{346}$

In terms of international law, pardons are not generally contested; however, amnesties for international crimes are widely seen as contrary to the obligations to investigate, prosecute and punish, laid down in treaties and customary international law. The Lomé Peace Agreement contained an amnesty that was raised in litigation at the Special Court for Sierra Leone. In Prosecutor v. Kallon et al., the Appeals Chamber held that

[the] court is entitled in the exercise of its discretionary power, to attribute little or no weight to the grant of such amnesty which is contrary to the direction in which customary international law is developing and which is contrary to the obligations in certain treaties and conventions the purpose of which is to protect humanity. ${ }^{347}$

The Human Rights Committee has addressed this matter of amnesties too. In General Comment No. 20 on Article 7 of the ICCPR, the Committee expressed concern over the use of amnesties in respect of torture and held that

amnesties are generally incompatible with the duty of States to investigate such acts; to guarantee freedom from such acts within their jurisdiction; and to ensure that they do not occur in the future. States may not deprive individuals of the right to an effective remedy, including compensation and such full rehabilitation as may be possible. $^{348}$

${ }^{346}$ Id., 131 I.L.R. 492 at 513 - 32, 521 ฯ 50.

${ }^{347}$ Prosecutor v. Morris Kallon and Brima Buzzy Kamara, Case No. SCSL-200415-AR72(E) and SCSL-2004-16-AR72(E), Decision on Challenge to Jurisdiction: Lomé Accord Amnesty, 84 (Mar. 13, 2004)

${ }^{348}$ Human Rights Committee, General Comment No. 20: Replaces general comment 7 concerning prohibition of torture and cruel treatment or punishment (Art. 7), 9 15, U.N. Doc. HRI/GEN/1/Rev.6 at 151 (Mar. 10, 1993). 
It has challenged States on this matter in reviewing their periodic reports, usually expressing the following concerns:

- the amnesty prevents relevant investigation and punishment of perpetrators of past human rights violations;

- the amnesty precludes proper compensation;

- the amnesty would contribute towards impunity and seriously undermine efforts to re-establish respect for human rights and to prevent a recurrence of the massive human rights violations experienced in the past;

- failure to exclude violators from service in Government, particularly in the military, the National Police and the judiciary, will seriously undermine the transition to peace and democracy. ${ }^{349}$

The Committee is likely to engage with Bangladesh in this manner in relation to Article 15 of the International Crimes (Tribunals) Act As Amended. In a number of individual communications, the Human Rights Committee has also addressed in the matter in the same way. In dealing with a communication challenging Argentina's 'Full Stop Law', the Committee reminded Argentina that 'it is under an obligation, in respect of violations occurring or continuing after the entry into force of the Covenant, thoroughly to investigate alleged violations and to provide remedies where applicable, for victims or their dependants". 350

${ }^{349}$ See Human Rights Committee, Comments on El Salvador, $\uparrow$ 7, U.N. Doc. CCPR/C/79/Add.34 (Apr. 18, 1994); Human Rights Committee, Comments on Paraguay, 9 9, U.N. Doc. CCPR/C/79/Add.48 (1995); Human Rights Committee, Comments on the Report submitted by Peru of 25 July 1996, 9 9, U.N. Doc. CCPR/79/Add.67 (1996); Human Rights Committee, Concluding Observations: Croatia, 11, U.N. Doc. CCPR/CO/71/HRV (Apr. 30, 2001).

${ }^{350}$ See R. A. V. N. et al. [names deleted] v. Argentina (No. 343/1988), - 5.4, U.N. Doc. U.N. Doc. CCPR/C/38/D/343/1988 (Mar. 26, 1990). On 24 December 1986, Argentina's Parliament adopted Law No. 23,492, known as the 'Finality Act' (Ley de Punto Final). This established a deadline of 60 days for commencing new criminal investigations with regard to the events of the so-called "Dirty War". This deadline expired on 22 February 1987. On 8 June 1987, Law No. 23,521, Parliament then adopted a law known as the 'Due Obedience' Act (Ley de Obediencia Debida), introducing an irrebuttable presumption that members of the security, police and prison services cannot be punished for such crimes if committed in due obedience to orders. The Act further extended protection to senior officers who did not have a decision-making role with regard to the violations. 


\subsection{Rules of Procedure and Evidence}

The normally applicable provisions of the Code of Criminal Procedure $1898,{ }^{351}$ and the Evidence Act, $1872,{ }^{352}$ used in the 1972 Collaborators Order, were expressly ousted in the 1973 Act and remain excluded after the 2009 amendments. Already back in 1974, the law provided that these 1971 cases would receive special treatment, subject to different standards from all other criminal cases in Bangladeshi courts. Section 19 makes it clear that the tribunal "shall not be bound by technical rules of evidence; and it shall adopt and apply to the greatest possible extent expeditious and non-technical procedure, and may admit any evidence, including reports and photographs published in newspapers, periodicals and magazines, films and tape-recordings and other materials as may be tendered before it, which it deems to have probative value". Article 19 goes on to provide for judicial notice of "facts of common knowledge" and also of "official governmental documents and reports of the United Nations and its subsidiary agencies or other international bodies including nongovernmental organizations". The removal of basic common law safeguards potentially expedites the proceedings; while this greatly relieves the prosecution of its heavy burden, it is done at the expense of the accused. However, in the absence of trial by a lay jury (trials will be by professional judges), this may not be as deleterious to the rights of the accused as would appear at first sight. The legislation antcipates that rules of procedure and evidence will be adopted by the judges. Processes of accountability for international crimes do require some flexibility in the rules of procedure and evidence, but there are limits to the concessions granted to the prosecuting authority. It is antithetical to a presumption of innocence and fundamental principles of equality before the law and fairness of the process if extensive concessions are deliberately introduced to facilitate the securing of convictions. In Cambodia, the much criticised ECCC process, facing challenges no less onerous than Bangladesh, follows rules of procedure and evidence that are rooted in the applicable domestic law and have been adapted to international practice in line with the statutory authorisation that

[i]f these existing procedure do not deal with a particular matter, or if there is uncertainty regarding their interpretation or application or if there is a question

351 Code of Criminal Procedure, supra note 89.

${ }^{352}$ Evidence Act, supra note 90. 
regarding their consistency with international standard, guidance may be sought in procedural rules established at the international level. ${ }^{353}$

The judges of the ECCC are required to "exercise their jurisdiction in accordance with international standards of justice, fairness and due process of law, as set out in Articles 14 and 15 of the 1966 International Covenant on Civil and Political Rights".354

One of the 2009 amendments to the Bangladeshi law was that "The tribunal shall be independent in the exercise of its judicial functions and shall ensure fair trial". 355 In international law, "fair trial" for a State that is party to the ICCPR means it must be conducted in accordance with that convention, particularly Articles 9 and 14. As already noted, Bangladesh cannot raise its domestic law as an excuse for non-compliance with binding international norms. ${ }^{356}$

Under Section 22 of the International Crimes (Tribunals) Act As Amended, a Tribunal may regulate its "own procedure", although subject to provisions in the act itself. There will obviously have to be extensive rules of procedure and evidence adopted in order to regulate the proceedings to ensure fair trial with due process. ${ }^{357}$ But, what currently regulates how the investigations are conducted if the Criminal Procedure Code, ${ }^{358}$ and the Evidence Act $^{359}$ regulating investigations and evidence gathering are ousted, there are no courtadopted Rules of Procedure and Evidence, and rudimentary (and unsatisfactory) provisions in the law itself? Matters of investigation, coercive measures, arrest, detention, surrender and extradition, etc.

${ }^{353}$ Law on ECCC, supra note 174, art 33. See also Internal Rules, Extraordinary Chambers in the Courts of Cambodia [Rev. 3], available at http://www.eccc.gov.kh (Mar. 3, 2009) ('ECCC Internal Rules').

${ }^{354}$ Law on ECCC, supra note 174, art 33.

${ }^{355}$ International Crimes (Tribunals) Act 1973 As Amended, supra note 79, Section 2(A) (newly added provision).

${ }^{356}$ VCLT, supra note 132, art 27 ("A party may not invoke the provisions of its internal law as justification for its failure to perform a treaty.") See also the sources quoted in supra note 148 for the rule as a general principle of international law.

${ }^{357}$ See e.g., ECCC Internal Rules, supra note 353; Rules of Procedure and Evidence (Amended) (10 June 2009), Special Trib. For Lebanon, STL/BD/2009/01/Rev. 1 (2009); Rules of Procedure and Evidence (Amended on 27 May 2008), Special Ct. for Sierra Leone (2008); Transitional Code of Criminal Procedure, U.N.Doc. UNTAET/REG/2000/30 (E. Timor) [hereinafter East Timor Transitional Code of Criminal Procedure].

358 Code of Criminal Procedure, supra note 89.

${ }^{359}$ Evidence Act, supra note 90. 
surely fall outside of the "own procedure" of the tribunal, these are not matters for the judges to regulate. The pre-trial phase is especially worrying given the reputation of the Bangladeshi police. ${ }^{360}$ The judges at the ICTY were granted specific powers to go outside the court-room: Article 15 of the Statute provided that "[t]he judges of the International Tribunal shall adopt rules of procedure and evidence for the conduct of the pre-trial phase of the proceedings, trials and appeals, the admission of evidence, the protection of victims and witnesses and other appropriate matters." The Cambodian law has been examined already. Even if one were to take an exceptionally liberal interpretation of "own procedure", this situation and the paucity of the existing rules in the law itself means that in Bangladesh, investigations and pre-trial work cannot begin until the judges adopt rules to regulate the work done at this stage.

\subsubsection{Investigations/The Pre Trial Stage of Proceedings}

Under Section 7, the government will appoint one or more persons to conduct the prosecution before a Tribunal on such terms and conditions as may be determined by the Government; and every such person shall be deemed to be a Prosecutor for the purposes of the Act. There will be a Chief Prosecutor. Under Section 8(1), the government may establish an Agency for the purposes of investigation into crimes within the jurisdiction. Any officer belonging to the Agency shall have the right to assist the prosecution during the trial. Any person appointed as a Prosecutor is competent to act as an Investigation Officer and the provisions relating to investigation shall apply to such Prosecutor. One would assume the Prosecutors supervise the investigations, but it is not clear from the legislation.

Section 8 provides some regulations of investigations and the pretrial stage of proceedings, but there are significant problems arising.

\footnotetext{
${ }^{360}$ See United States Department of State, 2008 Human Rights Report: Bangladesh, http://www.state.gov/g/drl/rls/hrrpt/2008/ (last visited Aug. 30, 2009). It details torture, death in custody and arbitrary detention by the police, and failure to investigate human rights violations. Human Rights Watch and Amnesty International have also called to attention the problem of unchecked torture and extrajudicial executions by organs of the State, in particular the Directorate General of Forces Intelligence (DGFI): See Human Rights Watch, Bangladesh: Stop Denying Killings and Torture, Oct. 6, 2008, http://www.hrw.org/en/news/2008/10/06/ bangladesh-stop-denying-killings-and-torture (last visited Aug. 30, 2009) and AMNESTY INTERNATIONAL, BANGLADESH: SUBMISSION TO THE UN UNIVERSAL PERIODIC REVIEW, 4TH SESSION OF THE UPR WORKING GROUP OF THE HUMAN RIGHTS COUNCIL, FEBrUARy 2009, AI Index: ASA/13/006/2008 (Sept. 1, 2008).
} 
Some of these are matters that the judges can deal with in their rules of procedure and evidence, assuming they do in fact have the powers to regulate the pre-trial phase. Provisions that are codified in the law will bind the tribunal. In terms of domestic law, there are problems that impact on the fundamental rights guaranteed by the Constitution (see earlier discussion). In terms of international law, Bangladesh, as a party to the ICCPR, is obliged to follow Article $9:^{361}$

1. Everyone has the right to liberty and security of person. No one shall be subjected to arbitrary arrest or detention. No one shall be deprived of his liberty except on such grounds and in accordance with such procedure as are established by law.

2. Anyone who is arrested shall be informed, at the time of arrest, of the reasons for his arrest and shall be promptly informed of any charges against him.

3. Anyone arrested or detained on a criminal charge shall be brought promptly before a judge or other officer authorized by law to exercise judicial power and shall be entitled to trial within a reasonable time or to release. It shall not be the general rule that persons awaiting trial shall be detained in custody, but release may be subject to guarantees to appear for trial, at any other stage of the judicial proceedings, and, should occasion arise, for execution of the judgement.

4. Anyone who is deprived of his liberty by arrest or detention shall be entitled to take proceedings before a court, in order that that court may decide without delay on the lawfulness of his detention and order his release if the detention is not lawful.

5. Anyone who has been the victim of unlawful arrest or detention shall have an enforceable right to compensation.

The only provision on arrest and detention is in Section 11(5): "Any member of a Tribunal shall have power to direct, or issue a warrant for, the arrest of, and to commit to custody, and to authorise the continued detention in custody of, any person charged with any crime specified in Section 3." This is problematic in terms of the ICCPR. Charging only comes at a later stage, i.e. under Section 9(1) when the Chief Prosecutor or Prosecutor formally lays charges, and there is no requirement that the prosecution evidence reasonable grounds to believe that a person has committed a crime. There is no minimum content for the Section 11(5) warrant. There is no provision that upon arrest, the suspect shall be informed of his or her rights, in accordance with the law, or to be given a copy of the warrant

${ }^{361}$ Bangladesh's reservation on the right of an accused to be present during his or her trial has already been discussed, and the declaration to the right to legal aid will be addressed later. 
detailing the allegations. The conditions for depriving a person of liberty are not set out in the law. Beyond Section 11(5), the law is silent on the procedures for carrying out arrest or detention of a suspect, and the period of time that the person may be deprived of liberty. There is no provision requiring that the person be brought "promptly" before a judge or other officer authorised by law (the Human Rights Committee has held in relation to Israeli preventive detention, that " $[\mathrm{t}]$ he State party should ensure that no one is held for more than $48 \mathrm{~h}$ without access to a lawyer" ${ }^{362}$ ), or requiring regular review of detention (which the Human Rights Committee regards as essential). ${ }^{363}$ There is no procedure by which the person can raise allegation of ill treatment or violations of his or her human rights by police officers or other authorities, or the unlawfulness of his or her detention. There are no criteria for assessing what sorts of factors would be reasonable grounds for prolonging detention (the usual factors to be considered would be the likelihood of flight, the risk of tampering with evidence, the risk of threats or harm to witnesses or danger of flight). There is nothing on the amount of time that a person can be held in detention pending trial: the ICCPR requires trial within "a reasonable time" or release, on the understanding that pre-trial detention "should be an exception and as short as possible". ${ }^{364}$

There is nothing requiring that the accused be given prompt notice of the accusations against him. Section 9(1), which provides for the commencement of proceedings upon the submission by the Chief Prosecutor, or a Prosecutor authorised by the Chief Prosecutor of formal charges, seems to be the first time that the accused is, by law, put on notice of the accusations against him. Article 14 of the ICCPR requires that the information about the charges be provided "promptly" and in detail in a language which the person understands. Even in armed conflict, the customary rule provides that the accused

${ }^{362}$ Human Rights Committee, Concluding Observations of the Human Rights Committee: Israel, 13, U.N. Doc. CCPR/CO/78/ISR (Aug. 21, 2003).

${ }^{363}$ Id., 9 21. In General Comment 29, the Committee held that judicial determination of lawfulness of detention may never be abrogated even if there is no such explicit stipulation in article 4 of the Covenant. This is founded on the principle that procedural guarantees must always remain in place to protect non-derogable rights: General Comment 29, supra note 146, ๆ 11, 15-16.

${ }^{364}$ Human Rights Committee, General Comment 8 on Article 9, 13, U.N. Doc. HRI/GEN/1/Rev.6 at 130 (Jun. 30, 1982). 
is to be informed "promptly" of the allegations against him; ${ }^{365}$ in fact the two protocols additional to the Geneva Conventions of 1949 provide that such information must be provided "without delay". 366 There is no provision on how long the investigators have to complete their investigation or a maximum period of detention of the person.

Simply by way of illustration, this free hand to the State to do whatever it wants in the matter of arrest and detention contrasts sharply with the law of the East Timor Special Panel for Serious Crimes. It is unusual to point to this particular process as a model of how to do international criminal justice in a domestic court, but the applicable law was undeniably sound on matters of arrest and detention:

6.2 Immediately upon arrest, the suspect shall be informed by the arresting police officers of the reasons for his or her arrest and any charges against him or her, and shall also be informed that he or she has the following rights:

(a) the right to remain silent and not to admit guilt, and that silence will not be interpreted as an admission;

(b) the right to contact a relative or close friend and be visited by such person;

(c) the right to contact a legal representative and communicate with him or her confidentially;

(d) the right that a legal representative will be appointed if the suspect is unable to pay for a lawyer;

(e) the right to be brought before an Investigating Judge within $72 \mathrm{~h}$ upon arrest;

(f) the right to be questioned in the presence of a legal representative, unless the right is waived; and

(g) if the suspect is a foreign national, the right to contact diplomatic or consular officials of his or her country.

$[\ldots]$

20.6 At the conclusion of the hearing the Investigating Judge may:

(a) confirm the arrest and order the detention of the suspect;

(b) order substitute restrictive measures instead of detention, as provided in Section 21 of the present regulation; or

(c) order the release of the suspect.

20.7 The Investigating Judge may confirm the arrest and order the detention of the suspect when:

(a) there are reasons to believe that a crime has been committed;

3651 CUSTOMARY INTERNATIONAL HUMANITARIAN LAW 359 (Jean-Marie Henckaerts \& Louise Doswald-Beck eds., 2005).

${ }^{366}$ Additional Protocol I, supra note 230, art 75(4); Additional Protocol II, supra note 231 , art $6(2)$. 
(b) there is sufficient evidence to support a reasonable belief that the suspect was the perpetrator; and

(c) there are reasonable grounds to believe that such detention is necessary.

20.8 Reasonable grounds for detention exist when:

(a) there are reasons to believe that the suspect will flee to avoid criminal proceedings;

(b) there is the risk that evidence may be tainted, lost, destroyed or falsified;

(c) there are reasons to believe that witnesses or victims may be pressured, manipulated or their safety endangered; or

(d) there are reasons to believe that the suspect will continue to commit offences or poses a danger to public safety or security.

20.9 The Investigating Judge shall review the detention of a suspect every thirty (30) days and issue orders for the further detention, substitute restrictive measures or for the release of the suspect. ${ }^{367}$

People are most vulnerable to abuse when they are first taken into custody. The International Crimes (Tribunals) Act As Amended contains no prohibition of incommunicado detention, nor torture, cruel, inhuman or degrading treatment, nor is there an express prohibition on the use of any evidence obtained under such conditions. While these critical pre-trial matters are not provided for, the recording of confessions by a magistrate is envisaged in Section 14. This framework suggests a system that will actively promote the practice of obtaining confessions, and reliance on them. The provision contains a sort-of safeguard that comes far too late in the process:

The Magistrate shall, before recording any such confession, explain to the accused person making it that he is not bound to make a confession and that if he does so it may be used as evidence against him and no Magistrate shall record any such confession unless, upon questioning the accused making it, he has reason to believe that it was made voluntarily. ${ }^{368}$

It is not accompanied by a provision allowing the Magistrate to investigate or prefer charges should it appear that the confession was coerced. As a State party to the Convention against Torture and Other Cruel, Inhuman or Degrading Treatment or Punishment, Bangladesh can under no circumstances allow statements which have

\footnotetext{
${ }^{367}$ East Timor Transitional Code of Criminal Procedure, supra note 357.

${ }^{368}$ International Crimes (Tribunals) Act 1973 As Amended, supra note 79, Section 14.
} 
been made as a result of prohibited acts to be used as evidence in proceedings against the person who made the confession. ${ }^{369}$ It is required to ensure prompt, impartial and full investigations into all complaints, plus accountability. No exceptional circumstances whatsoever, whether a state of war or a threat of war, internal political instability or any other public emergency, may be invoked as a justification of torture, under Article 2(2).

Common law jurisdictions have always placed importance on the right to silence at all stages of the criminal justice process (even if the exact scope of that right is controversial), and international human rights law emphasises the presumption of innocence and protection of the suspect against self-incrimination. Article 14(2) of the ICCPR states that everyone charged with a criminal offence shall have the right to be presumed innocent until proved guilty according to law. Article $14(3)(\mathrm{g})$ provides that in the determination of any criminal charges against him, everyone shall be entitled to, inter alia, the minimum guarantee, in full equality of not being compelled to testify against himself or to confess guilt. In 2008, the Human Rights Committee asked France to ensure that "[a]nyone arrested on a criminal charge should be informed of the right to remain silent during police questioning, in accordance with article 14, paragraph 3 (g), of the Covenant." ${ }^{370}$ All of the ICTY, ICTR and ICC explicitly recognise the right to silence, already at the investigation stage; the ICC Statute goes the furthest in stating that silence cannot be used as "a consideration in the determination of guilt or innocence". 371 Having defence counsel present during pre-trial custodial questioning is critical in order to protect these rights at a time when the person is at greatest risk of intimidation and physical ill-treatment. ${ }^{372}$ In its

${ }^{369}$ Convention Against Torture and Other Cruel, Inhuman Or Degrading Treatment Or Punishment, art 15, Dec. 10, 1984, 1465 U.N.T.S. 85 (entered into force Jun. 26, 1987, Bangladesh acceded on Oct. 5,1998).

${ }^{370}$ Human Rights Committee, Consideration of Reports Submitted by State Parties Under Article 40 of the Covenant: Concluding Observation of the Human Rights Committee - France, 1 14, U.N. Doc. CCPR/C/FRA/CO/4 (Jul. 31, 2008).

${ }^{371}$ ICC Statute, supra note 98, art 67.

372 The European Committee for the Prevention of Torture recommends that the right of access to a lawyer is guaranteed from the very outset of police custody. See European Committee for the Prevention of Torture and Inhuman or Degrading Treatment or Punishment, Second General Report on the CPT's Activities covering the Period 1 January to 31 December 1991, $\uparrow 36$, Doc. CPT/Inf(82)3[EN] (Apr. 13,1992); Reiterated in European Committee for the Prevention of Torture and Inhuman or Degrading Treatment or Punishment, The CPT Standards: "Substantive" Sections of 
General Comment No. 2, the Committee against Torture, which monitors compliance with the Convention against Torture, Cruel, Inhuman and Degrading Treatment, has stressed that the right of detainees promptly to receive independent legal assistance is one of the basic guarantees against torture and ill-treatment of persons deprived of their liberty. ${ }^{373}$ It is one of the fundamental safeguards against such acts. International documents of the "soft law" variety also stress the significance of counsel and prescribe some timeframes. ${ }^{374}$

The International Crimes (Tribunals) Act As Amended contains no provision affirming the right to have counsel during the critical pre-trial phase. As such, it does not require that the suspect be advised of his rights on being deprived of his liberty, including the right not to answer questions without defence counsel present. It contains no provision prohibiting questioning of the person in the absence of a defence counsel, if he opts to have such a counsel present. There is a provision, in Section 12, allowing for the Tribunal, "at any stage of the case" to appoint counsel for an unrepresented accused. This is not a right to counsel, it is a discretionary power of the court (the provision says the Tribunal "may" take such steps). And, there is no

Footnote 372 continued the CPT's General Reports, - 36, Doc CPT/Inf/E (2002) 1, Rev. 2006 (Oct. 2006).

In November 2008, the Grand Chamber of the European Court of Human Rights held that under Article 6(1) of the European Convention on Human Rights, access to a lawyer should be provided from the very first interrogation of a suspect by the police. That may be subject to exception but not when it unduly prejudices the rights of the accused under Article 6. "The rights of the defence will in principle be irretrievably prejudiced when incriminating statements made during police interrogation without access to a lawyer are used for a conviction." See Salduz v. Turkey, App No. 36391/02 ECHR, 55 (Nov. 27, 2008), available at http://www.echr.coe.int/eng.

373 Committee Against Torture, General Comment 2: Implementation of article 2 by States Parties, $\uparrow 11$, U.N. Doc. CAT/C/GC/2/CRP. 1/Rev.4 (Jan. 24, 2008).

374 Principle 15 of the non-binding Body of Principles for the Protection of All Persons under Any Form of Detention or Imprisonment recommends that access to legal representation must be given in "a matter of days". See Body of Principles for the Protection of All Persons under Any Form of Detention or Imprisonment, G.A. Res. 43/173, Annex, U.N. GAOR 43th Sess. Supp. (No. 49) at 298, U.N. Doc. A/43/49 (Dec. 9, 1988).Principle 7 of the also non-binding Basic Principles on the Role of Lawyers is more specific, specifying $48 \mathrm{~h}$ as the time limit for providing a person with access to legal counsel. See Basic Principles on the Role of Lawyers, Eighth United Nations Congress on the Prevention of Crime and the Treatment of Offenders, Havana, 27 August to 7 September 1990, U.N. Doc. A/CONF.144/28/Rev.1 at 118 (1990). 
provision for hearing an application from a detained person on this matter of legal counsel, nor is there any requirement on the investigators to inform the person that there is a possibility of legal counsel being assigned. Also, there is no provision affirming the right of the accused to communicate freely with counsel, or to be given "sufficient time and resources" to prepare his defence.

In the absence of any right to the assistance of legal counsel at the investigative/pre-trial stage, Sections 8(4)-(5) create obvious problems with the presumption of innocence and the right to silence, specifically its component protecting a person from self-incrimination:

(4) Any Investigation Officer making an investigation under this Act may examine orally any person who appears to be acquainted with the facts and circumstances of the case.

(5) Such person shall be bound to answer all questions put to him by an Investigation Officer and shall not be excused from answering any question on the ground that the answer to such question will criminate, or may tend directly or indirectly to criminate, such person: Provided that no such answer, which a person shall be compelled to give, shall subject him to any arrest or prosecution, or be proved against him in any criminal proceeding. ${ }^{375}$

Any witness is going to be at risk by the following provision:

18. A witness shall not be excused from answering any question put to him on the ground that the answer to such question will criminate or may tend directly or indirectly to criminate such witness, or that it will expose or tend directly or indirectly to expose such witness to a penalty or forfeiture of any kind: Provided that no such answer which a witness shall be compelled to give shall subject him to any arrest or prosecution or be proved against him in any criminal proceeding, except a prosecution for giving false evidence. ${ }^{376}$

There are other problems, such as Section 8(6), allowing the Investigating Officer to "reduce into writing any statement made to him in the course of examination", which does not require verification by an accused or his/her counsel.

\subsubsection{Commencement of Proceedings, Including Trial Procedures}

The International Crimes (Tribunals) Act As Amended provides for the commencement of proceedings in Section 9 and the basic order of proceedings in Section 10, which is standard common law. Importantly, it allows the defence to cross-examine witnesses. The

${ }^{375}$ International Crimes (Tribunals) Act 1973 As Amended, supra note 79, Sections 8(4)-(5) (emphasis added).

${ }^{376}$ Id., Sections 8(4)-(5) (emphasis added). 
proceedings will be in public, unless the court sees fit to hold proceedings in camera. The proceedings before a Tribunal shall commence upon the submission by the Chief Prosecutor, or a Prosecutor authorised by the Chief Prosecutor, of formal charges of crimes alleged to have been committed by each of the accused persons. The procedure for trial allows for the charges to be read, ${ }^{377}$ taking of the plea, opening statements, examination in chief followed by cross examination followed by re examination, etc. It is only at this stage that the accused, who will probably have already been in custody for some indeterminate period of time, and interrogated without a lawyer present, gets notice of the matter with which he is charged (Section 16 provides for "particulars of the alleged crime as are reasonably sufficient to give the accused person notice of the matter with which he is charged"). As already noted, the ICCPR requires that notice of the charges must be provided "in detail".

In what is probably a touch of the civil lawyers who advised the government at the time, there is a provision that the Tribunal

may, in order to discover or obtain proof of relevant facts, ask any witness any question it pleases, in any form and at any time about any fact; and may order production of any document or thing or summon any witness, and neither the prosecution nor the defence shall be entitled either to make any objection to any such question or order or, without the leave of the Tribunal, to cross-examine any witness upon any answer given in reply to any such question. ${ }^{378}$

\section{There are rules governing evidence in Section 19:}

(1) A Tribunal shall not be bound by technical rules of evidence; and it shall adopt and apply to the greatest possible extent expeditious and non-technical procedure, and may admit any evidence, including reports and photographs published in newspapers, periodicals and magazines, films and tape-recordings

377 The requirements of the charge are set out in Section 16:

(1) Every charge against an accused person shall state: (a) the name and particulars of the accused person; (b) the crime of which the accused person is charged; (c) such particulars of the alleged crime as are reasonably sufficient to give the accused person notice of the matter with which he is charged. (2) A copy of the formal charge and a copy of each of the documents lodged with the formal charge shall be furnished to the accused person at a reasonable time before the trial; and in case of any difficulty in furnishing copies of the documents, reasonable opportunity for inspection shall be given to the accused person in such manner as the Tribunal may decide.

${ }^{378}$ International Crimes (Tribunals) Act 1973 As Amended, supra note 79, Section 10(h). 
and other materials as may be tendered before it, which it deems to have probative value.

(2) A Tribunal may receive in evidence any statement recorded by a Magistrate or an Investigation Officer being a statement made by any person who, at the time of the trial, is dead or whose attendance cannot be procured without an amount of delay or expense which the Tribunal considers unreasonable.

(3) A Tribunal shall not require proof of facts of common knowledge but shall take judicial notice thereof.

(4) A Tribunal shall take judicial notice of official governmental documents and reports of the United Nations and its subsidiary agencies or other international bodies including non-governmental organisations. ${ }^{379}$

\section{The closest that come to disclosure rules are the following provisions in Section 9:}

(3) The Chief Prosecutor shall, at least three weeks before the commencement of the trial, furnish to the Tribunal a list of witnesses intended to be produced along with the recorded statement of such witnesses or copies thereof and copies of documents which the prosecution intends to rely upon in support of such charges.

(4) The submission of a list of witnesses and documents under Sub-section (3) shall not preclude the prosecution from calling, with the permission of the Tribunal, additional witnesses or tendering any further evidence at any stage of the trial: Provided that notice shall be given to the defence of the additional witnesses intended to be called or additional evidence sought to be tendered by the prosecution.

(5) A list of witnesses for the defence, if any, along with the documents or copies thereof, which the defence intends to rely upon, shall be furnished to the Tribunal and the prosecution at the time of the commencement of the trial.

Three weeks before the start of trial is hardly sufficient time to prepare the defence against charges of the kind covered in the International Crimes (Tribunals) Act As Amended.

\section{The powers of the tribunal are laid out in Section 11:}

(1) A Tribunal shall have power: (a) to summon witnesses to the trial and to require their attendance and testimony and to put questions to them; (b) to administer oaths to witnesses; (c) to require the production of document and other evidentiary material; (d) to appoint persons for carrying out any task designated by the Tribunal.

(2) For the purpose of enabling any accused person to explain any circumstances appearing in the evidence against him, a Tribunal may, at any stage of the trial without previously warning the accused person, put such questions to him as the Tribunal considers necessary: Provided that the accused person shall not

\footnotetext{
${ }^{379} I d$., Section 11.
} 
render himself liable to punishment by refusing to answer such questions or by giving false answers to them; but the Tribunal may draw such inference from such refusal or answers as it thinks just;

(3) A Tribunal shall: (a) confine the trial to an expeditious hearing of the issues raised by the charges; (b) take measures to prevent any action which may cause unreasonable delay, and rule out irrelevant issues and statements.

(4) A Tribunal may punish any person, who obstructs or abuses its process or disobeys any of its orders or directions, or does anything which tends to prejudice the case of a party before it, or tends to bring it or any of its members into hatred or contempt, or does anything which constitutes contempt of the Tribunal, with simple imprisonment which may extend to 1 year, or with fine which may extend to Taka five thousand, or with both.

(5) Any member of a Tribunal shall have power to direct, or issue a warrant for, the arrest of, and to commit to custody, and to authorise the continued detention in custody of, any person charged with any crime specified in Section 3.

(6) The Chairman of a Tribunal may make such administrative arrangements as he considers necessary for the performance of the functions of the Tribunal under this Act. ${ }^{380}$

Article 11(2) is remarkable. It appears to discard the traditional common law right to silence as well as the protection against selfincrimination, and codifies trial-by-ambush in the form of surprise judicial questioning:

For the purpose of enabling any accused person to explain any circumstances appearing in the evidence against him, a Tribunal may, at any stage of the trial without previously warning the accused person, put such questions to him as the Tribunal considers necessary: Provided that the accused person shall not render himself liable to punishment by refusing to answer such questions or by giving false answers to them; but the Tribunal may draw such inference from such refusal or answers as it thinks just. ${ }^{381}$

This is a provision that must not be allowed to stand.

The standard of proof in these proceedings is not stated. In its General Comment No. 13, the Human Rights Committee interpreted Article 14 to mean that "by reason of the presumption of innocence, the burden of proof of the charge is on the prosecution and the accused has the benefit of the doubt. No guilt can be presumed until

\footnotetext{
${ }^{380} I d$., Section 11.

${ }^{381}$ Id., Section 11(2).
} 
the charge has been proved beyond a reasonable doubt." 382 This must be the applicable standard in the Bangladeshi process.

\subsubsection{Victims and Witnesses}

The wounds are still very raw in Bangladesh. Victims can be heard complaining that there is more concern shown about the rights of an accused than their rights. But this overlooks the fact that the whole effort to bring to account alleged criminals is about using the criminal process to bring justice to the victims and restore equilibrium in society. If the victims want to have a criminal justice process, they have to accept that central in that is the right of an accused person to a fair trial with due process before an independent and impartial tribunal. That is non-negotiable, no matter how much the victims have been through. It is only that kind of proceeding that is worthy of hearing the sorts of atrocity allegations that are made in Bangladesh about the 1971 war. A conviction in a kangaroo court is of no value whatsoever; thankfully, that does not seem to be what is being attempted in Bangladesh. It is another reason why Bangladesh needs to bring its 1973 Act up to the modern day and age. Today, victims are recognised as legitimate stakeholders in international legal proceedings, not just commodities to be used by prosecution and defence (which continues to be the case in the common law system, which is what Bangladesh is following). But, as with most things, there is a difficult balance to be struck. One can use an example from Cambodia. After heavy lobbying from victims groups and NGOs, there is now disturbing distortion of the criminal justice process with excessive participation by the civil parties in the proceedings, to the extent that the presumption of innocence and the level playing field between prosecutor and defence are seriously impaired. One can expect, if there is a conviction, that Duch $^{383}$ will appeal on the ground of violation of basic human rights standards because the excessive and inappropriate involvement of the civil parties in the proceedings impacted on the accused's right to a fair trial and due process.

The only protective provision in the International Crimes (Tribunals) Act As Amended is in Section 10(4), under which "the Tribunal may, if it thinks fit, take proceedings in camera". Beyond this, there is nothing on witness protection or support. There seems to

${ }^{382}$ Human Rights Committee, General Comment 13: Article 14, U.N. Doc. HRI/ GEN/1/Rev.6 at 135 (Apr. 13, 1984).

${ }^{383}$ This accused was the commander of the infamous S-21 torture centre in Phnom Penh. 
be paucity across the board: a provision exists in the Prevention of Oppression Women and Children Act 2000, which allows for there to be provided "safe custody" for women and children during trial. ${ }^{384}$ Under this section, the tribunal can order that women and children be kept outside the jail in a government approved place or under the custody of any person or organisation the Tribunal thinks fit. The reference to "jail" suggests that this is applicable only for the protection of convicted persons. The paucity of witness protection and support in the International Crimes (Tribunals) Act, even after the 2009 amendment, is even worse than that which was in the equivalent Indonesian legislation governing the East Timor trials at the ad hoc Court for Human Rights Violations in East Timor: Article 34 of the Law on Human Rights Courts provided that victims and witnesses of gross violations of human rights had "the right to physical and mental protection from threats, harassment, terror, and violence by any party whosoever" and that such protection is "an obligatory duty of the law enforcement and security apparatus provided free of charge". ${ }^{385}$ A government regulation on witness protection in cases before the human rights courts was rushed through as the first of the East Timor trials was beginning. There were just three options for protection in Section 4 of the regulation: protection of the victim or witness' personal security from physical or mental threats; confidentiality of the identity of the victim or witness; testifying to the court out of the presence of the accused. While this was the first witness protection measure as such, it was clearly not the specialised witness protection regime that was needed, leading to atrocious handling of victims and witnesses during the trials. This must not happen in Bangladesh.

There is now a wealth of international experience, culminating in the exceptionally complex and demanding regime of the ICC, that should be drawn on in order to ensure that witnesses and victims in Bangladesh are properly supported, and protected as necessary, at all stages of the proceedings. Of course, it is unrealistic to expect Bangladesh to cope with the heavy witness protection obligations that apply at the ICC. But, it cannot proceed to trial on the basis of the current state of the law. A realistic yet principled balance has to be struck, which takes into consideration what is actually possible in the circumstances of Bangladesh. Particular concerns arise in relation to

${ }^{384}$ Prevention of Oppression of Women and Children Act 2000, Act VIII of 2000, Section 31 (Bangl.).

${ }^{385}$ See Linton, supra note 88 and Linton, supra note 151. 
the handling of sexual offences, which are said to have been particularly rampant during the war. Firstly, this is a Moslem society, and much of the recent developments in this area are based on Western victim-restoration notions about the importance of victims speaking out about their experiences; this does not necessarily translate well to countries such as Bangladesh. Secondly, this is a common law jurisdiction, and the witness is a commodity of the parties and the courtroom experience can be particularly traumatic. Let us take the example of someone accused of the abduction and unlawful detention of women on a military base where they were used as sex slaves. The prosecution team find a survivor. She will firstly be questioned by investigators. Are they trained in gender sensitivity and the investigation of crimes of sexual violence? What kind of care or support is she given? What about protecting her identity, or other forms of personal protection if there are legitimate concerns about her safety? She is then brought to court to testify. Apart from "in camera" proceedings, what other protections can the court afford her? Will there be any expunging of names and identifying information from the documents, or non-disclosure to the public of records identifying the victim, or provision for her to testify through image or voice altering devices or closed-circuit television, or the assignment of a pseudonym so her real name is not revealed? If she had a child born of rape, how will that the identity of that child, now an adult, be protected? Will the court be able to provide psycho-social support as she goes through the trauma of recounting events she has probably locked away in the dark recesses of her mind for 39 years? And what of her family, how will they be supported through this process? How will the court regulate the questioning of the victim in the court room? Will there be any protections in the courtroom, such as are provided at the ICTY, where Rule 96 of the Tribunal's Rules of Procedure and Evidence provides that (a) there is not need for no corroboration of evidence given by victims of sexual violence (b) the manifestation of consent cannot be invoked as any form of captivity vitiates consent (c) the defence must satisfy the Trial Chamber in camera that the evidence of consent is relevant and credible, and (d) the prior sexual conduct of the victim cannot be permitted as evidence. Who and what are to protect the victim from rigorous cross-examination by a defence counsel who believes he is just doing his job of defending his client? When it is all over, what after-care and support is provided to the victim, who may suffer re-traumatisation as a result of reliving the terrible experiences? What kind of protection will be provided to her, 
against retaliatory attacks? What kind of remedy will be made available to her, whether or not a conviction results? These are issues that seem not to have been considered in Bangladesh.

\subsubsection{Suggestions for Content of Rules of Procedure and Evidence}

There are basic issues that cut across all processes of accountability that have been conducted since the rudimentary nature of the proceedings at Nuremberg. In addition to the issues that I have raised in this paper, the following need to be addressed:

- Procedure on a guilty plea.

- Interlocutory applications.

- Evidence: for example, burden and standard of proof, disclosure (including of exculpatory evidence), admissibility and evaluation of evidence, means of proof, written or oral, rules for particular witnesses (e.g. ICRC, journalists, experts, amicus curiae, etc.).

- Special issues arising from multiple accused trials, including joint charging.

- Indictments: cumulative or consecutive charging.

- Deliberation, the making of decisions and judgements (unanimity or majority), cumulative or consecutive convictions, dissent, etc.

- Sentencing considerations, especially the sentencing practice in Bangladesh.

- Role of victims, victims rights, victim and witness support and protection.

- Reparations (although the scale of the harms suffered means that there really should be a national scheme for reparations, rather than individualised reparations for the 'lucky' ones whose cases get heard).

The procedural rules for the ECCC, Special Tribunal for Lebanon, War Crimes Chamber of the Court of Bosnia and Herzegovina and the Special Panel for Serious Crimes in East Timor should be particularly closely - and critically - consulted, as they are closer to the circumstances of Bangladesh than the ICC, Special Court for Sierra Leone, ICTY and ICTR.

\subsection{Appeal}

Appeal to the Appellate Division of the Supreme Court is only possible, under Section 21 as amended in 2009, in relation to convictions, sentence or acquittals. 
Article 24 provides that no order, judgement or sentence of a Tribunal shall be called in question in any manner whatsoever in or before any Court or other authority in any legal proceedings whatsoever except in the manner provided in Section 21. This supplements the constitutional ban on challenging the law and its provisions on the grounds of constitutionality, and blocks off any form of challenge to anything other than the ultimate decision taken by the trial chamber. There can, for example, be no challenges arguing unlawfulness of arrest or detention, violation of defence rights in the trial proceedings, or impartiality of the judges. This is a major human rights concern.

\subsection{Remedies}

There is nothing on remedies in the International Crimes (Tribunals) Act As Amended, although a liberal interpretation of the power of the court to impose "such other punishment proportionate to the gravity of the crime as appears to the Tribunal to be just and proper" may allow reparations orders to be made. Whether there is any compensation to actually come is another matter.

In general Bangladeshi law, there are no specific provisions providing civil remedies for victims of crime. But the issue of compensation is covered in Section 545 of the Code of Criminal Procedure, according to which a court can award compensation out of the fines ordered against convicted persons. This provision is applicable at every stage of the suit. There is also provision for fines from "inheritable property in future" under the Prevention of Oppression of Women and Children Act 2000: the Tribunal may consider imposing a fine for the benefit of the victim in circumstances

where the fine cannot be realized from the convict or from his existing property, it can be realized from the property of which he will be the owner or in possession in future and the claim of such fine or damage shall prevail over any other claim on that property. ${ }^{386}$

There is no national programme of reparations for the victims and survivors of 1971, whether compensatory or symbolic. These national programmes of reparation are devices for assisting in the wider social recovery of a society. The position of Bangladesh can be seen in the following. In acceding to the Convention against Torture and Other

${ }^{386}$ Prevention of Oppression of Women and Children Act 2000, supra note 384, Section 15. 
Cruel, Inhuman or Degrading Treatment or Punishment, Bangladesh entered a declaration to Article 14 on the provision of redress to victims of torture. ${ }^{387}$ Article 14(1) provides that

Each State Party shall ensure in its legal system that the victim of an act of torture obtains redress and has an enforceable right to fair and adequate compensation including the means for as full rehabilitation as possible. In the event of the death of the victim as a result of an act of torture, his dependents shall be entitled to compensation.

Bangladesh's declaration was that it would apply the provision "in consonance with the existing laws and legislation in the country." 388 There have been objections to this declaration from Germany (on grounds that this is a reservation of a general nature raising doubts as to the commitment of Bangladesh to the object and purpose of the treaty) ${ }^{389}$ and The Netherlands (on grounds that this reservation raises doubts as to the commitment of Bangladesh to the object and purpose of the treaty). ${ }^{390}$ Neither declares the declaration to be contrary to the object and purpose of the convention.

There is no remedy for miscarriage of justice under the International Crimes (Tribunals) Act As Amended, "provided the government acted in good faith pursuant to the act" ". ${ }^{391}$ Compensation for miscarriage of justice is a matter on which Bangladesh has entered a reservation to Article 14 of the ICCPR.

The Government of the People's Republic of Bangladesh, notwithstanding its acceptance of the principle of compensation for miscarriage of justice, as stipulated in Article 14, paragraph 6, is not in a position to guarantee a comprehensive implementation of this provision for the time being. However, the aggrieved has the right to realise compensation for miscarriage of justice by separate proceedings and in some cases, the court suo moto grants compensation to victims of miscarriage of

${ }^{387}$ See Bangladesh's Declaration to the Convention Against Torture, hhttp:// treaties.un.org/Pages/ViewDetails.aspx? $s r c=$ TREATY\&mtdsg_no $=$ IV-9\&chapter $=4$ \&lang $=$ en (last visited Aug. 30, 2009).

${ }^{388} \mathrm{Id}$.

${ }^{389}$ See Communication from Germany (Dec. 17, 1999), http://treaties.un.org/ Pages $/$ ViewDetails.aspx?src $=$ TREATY\&mtdsg_no $=$ IV-9\&chapter $=4 \&$ lang $=$ en $\# 14$ (last visited Aug. 30, 2009).

${ }^{390}$ See Communication from the Netherlands (Dec. 20, 1999), http://treaties. un.org/Pages/ViewDetails.aspx?src $=$ TREATY\&mtdsg_no $=$ IV-9\&chapter $=4 \&$ lang $=$ en\#14 (last visited Aug. 30, 2009).

${ }^{391}$ International Crimes (Tribunals) Act 1973 As Amended, supra note 79, Section 25 . 
justice. Bangladesh, however, intends to ensure full implementation of this provision in the near future. ${ }^{392}$

\subsection{Death Penalty}

Section 20, providing for the death penalty or "other such punishment proportionate to the gravity of the crime as appears to the Tribunal to be just and proper", is retained.

There is no prohibition against the death penalty in international law as yet, but many commentators have observed a clear evolution in the law tending towards outlawing of this penalty. ${ }^{393}$ Iraq also kept the death penalty, and the notorious trial of Saddam Hussein came to an even more ignominious end with his grotesquely botched execution. The death penalty was used in the post World War II trials and on Eichmann, but outside of Iraq, has not been used since in modern international justice proceedings, whether the ICTY, ICTR, Special Panels for Serious Crimes in East Timor, ECCC, SCSL or the Special Court for Lebanon. The Human Rights Committee has urged States parties to the ICCPR to move towards abolition; in the event that they continue to retain the death penalty, the procedural guarantees of the ICCPR "must be observed, including the right to a fair hearing by an independent tribunal, the presumption of innocence, the minimum guarantees for the defence, and the right to review by a higher tribunal". The Working Group on the Universal Periodic Review examining Bangladesh's report "strongly" encouraged Bangladesh to abolish the death penalty, and pending that, to adopt a moratorium on executions. It was also recommended that Bangladesh should consider "amending their legislation on the death penalty in order to restrict its scope and adjust it to the international minimum standards on the death penalty..." 394 Other legislation in Bangladesh, for example the Prevention of Oppression Against Women and Children Act 2000, follow the Code of Criminal Procedure's Section 374 which

\footnotetext{
392 See Bangladesh's Reservation to the ICCPR, supra note 154.

393 See william A. SCHABas, THE AbOlition OF THE DEATH PENALTY IN INTERNATIONAL LAW 1, 5-6 (2002).

${ }^{394}$ Human Rights Council, Report of the Working Group on the Universal Periodic Review: Bangladesh, 9 94, U.N. Doc. A/HRC/11/18 (Mar. 3, 2009); Implementation of the Safeguards Guaranteeing Protection of the Rights of Those Facing the Death Penalty, E.S.C. Res. 1984/50, annex, U.N. ESCOR 1984 Supp. (No. 1) at 33, U.N. Doc. E/1984/84 (May 25, 1984).
} 
requires that a death sentence shall not be executed unless it is confirmed by the High Court Division. Yet, there is no mandatory review under the International Crimes (Tribunals) Act As Amended, even though it was just amended in 2009. Given what has been discussed in the preceding pages about the process of accountability in Bangladesh, there is much reason for grave concern.

\section{CONCLUDING OBSERVATIONS}

The domestic court is always the place where accountability should start. It was remarkable and admirable that Bangladesh, with the support of its friends abroad, adopted this important legislation back in 1973. No one denies that Bangladesh, as the territorial State, has the primary right to take jurisdiction. It is right and proper, and Bangladesh is to be applauded for doing so.

But there seems to be an unwillingness, perhaps inability, to comprehend exactly how enormous and complicated the task of investigating, prosecuting and punishing such cases is. Efforts of international specialists to facilitate essential training of personnel, in advance of the project's start-up, have been unsuccessful; official thinking seems to be that preparation of personnel for the task at hand is not really needed and will just slow a straight-forward process down. After so many years of accountability being put into a deep freeze, people are understandably anxious to seize the moment and forestall any backsliding. There is a clear lack of awareness about how long it takes to prepare for such proceedings, and how long these trials take. There is, however, a disturbing ease with which legitimate concerns about the capacity to guarantee fair trial and due process, including the political targeting of one group's enemies, are brushed aside. The reasons for insisting on fair trial and due process do not really seem to be appreciated, leading to a misperception among some that the 'war criminals' count more than victims and that to insist on adequate standards is to 'support the war criminals'. A well-intentioned paper such as I have written is going to be viewed in these quarters as unhelpful, anti-victim and anti-accountability for pointing out various flaws and complexities that need to be addressed before the process actually begins. Many seem to think that it is just a matter of touching up the law, setting aside something in the budget, appointing the staff and getting going with the job of convicting the persons who are, incidentally, already convicted in much of the public mind. It is not. 
The complications exposed in this study of the Bangladeshi legislation reveal just how complex the legal challenges on their own are. Most of these do requiring fixing before the process begins. Then there are all the practical and procedural problems that are inherent in any project to bring accountability for international crimes, let alone in a developing country with a UNDP Human Development Index ranking of 147 out of $179(2008)^{395}$ and 39 years after the event. Some of these can also still be addressed, such as through advance specialised training of the personnel to be involved, and the adoption of workable and adequate rules of procedure and evidence. It is, of course, not a matter of importing in the provisions of the ICC Statute, for East Timor has shown how ridiculous it is to expect a dysfunctional domestic system in one of the world's most devastated and impoverished countries to be able to cope with the gold standard established for an international criminal court. Here, it seems to be a matter of making the process in Bangladesh meet basic, not five star, international standards. If the consistent reports of international observers about the state of the criminal justice system in Bangladesh are indeed reliable, there is reason to be concerned about the ability of the underlying system to cope with this monumental exercise in overdue accountability as a $100 \%$ domestic process. ${ }^{396}$ We have the

${ }^{395}$ United Nations Development Programme, Human Development Indices: A statistical update 2008 - HDI rankings, http://hdr.undp.org/en/statistics/ (last visited Aug. 9, 2009).

396 The Special Representative of the Secretary-General on human rights defenders and the Special Rapporteur on the independence of judges and lawyers expressed concerns about threats and attacks against the judiciary in Bangladesh; there are concerns about targeting the judiciary to apply Islamic laws and the safety of judges and lawyers and their freedom to carry out their legal work without pressure, threats or interference. See Human Rights Council, Compilation Prepared by the Office of the High Commissioner for Human Rights, In Accordance with Paragraph 15(B) of the Annex to Human Rights Council Resolution 5/1: Bangladesh, 1 22, U.N. Doc. A/HRC/WG.6/4/BGD/2 (Dec. 12, 2008).

The United States Department of State, 2008 Human Rights Report on Bangladesh details torture, death in custody and arbitrary detention by the police, and failure to investigate human rights violations. It details severe delays impacting on the right to expeditious trial. In relation to the courts, it is alleged that corruption, judicial inefficiency, lack of resources, and a large case backlog remained serious problems, trials are

typically marked by extended continuances, effectively preventing many from obtaining a fair trial due to witness tampering, victim intimidation, and missing evidence. Human rights observers contended that magistrates, attorneys, and court officials demanded bribes from defendants in a majority of the 
precedents of Ethiopia, East Timor, Indonesia, Iraq and Cambodia, all also burdened by weak criminal justice systems but proceeding with accountability for international crimes, to stand as cautionary tales for Bangladesh as it tries to do it alone. There are salutary lessons for Bangladesh from Rwanda's brave effort to develop its own process of legal accountability in prosecuting the crimes of the 1994 genocide in its domestic courts, efforts that ultimately failed and led the government to develop parallel forms of justice through gacaca courts. The 2009 addition to the Bangladeshi 1973 law stating that "The tribunal shall be independent in the exercise of its judicial functions and shall ensure fair trial" ${ }^{397}$ are just fine words of the kind that already exist in the Constitution. Much more is needed.

International crimes of the utmost seriousness were committed in Bangladesh in 1971, and the way that these are handled is of legitimate concern to the international community. Now that a political space has opened and accountability is coming out of the deep-freeze, the international community needs to become engaged in assisting to make this a worthy process that can bring Bangladeshis the justice that is due to them, 37 years after they first started the effort. Completing the circle is a task that cannot be done by Bangladesh on its own.

Footnote 396 continued

cases filed under the Special Powers Act"..."The prison system remained abysmal due to overcrowding, inadequate facilities, and the lack of proper sanitation (see U.S. Department of States, supra note 360).

See also Amnesty International, supra note 360, at 5-6 (Detailing problems of incommunicado detention, torture and other ill-treatment; it has also detailed unfair trials) and Human Rights Watch, supra note 360 (calling to attention the problem of unchecked torture and extrajudicial executions by organs of the State, in particular the Directorate General of Forces Intelligence (DGFI)).

See also Asian Human Rights Commission, Special Report: Lawless Law-Enforcement \& the Parody of Judiciary in Bangladesh, August 2006, and Md. Ashrafuzzaman, The Disposable Prosecutors of Bangladesh, http://www.article2.org/mainfile. php/0701/309/ (last visited Oct. 9, 2009).

${ }^{397}$ International Crimes (Tribunals) Act 1973 As Amended, supra note 79, Section 2(A) (newly added provision). 